\title{
Building Stories:
}

\author{
Oral History, Built Heritage \\ \& Numinous Fabric
}

\author{
By \\ Miranda Williamson \\ A thesis submitted to Victoria University of Wellington \\ in fulfilment of the requirements for the degree of \\ Master of Arts \\ in Museum and Heritage Studies
}

Victoria University of Wellington 2019 


\begin{abstract}
Carman and Sørensen's book Heritage Studies: Methods and Approaches challenges us to reconsider and extend methodologies in heritage studies. This thesis takes inspiration from their book to ask how and why heritage practitioners and academics researching built heritage should use oral history as a useful qualitative tool in their research process. In the New Zealand context, researchers find it difficult to find information for the period that spans the Second World War to the present, due to the common practice of restricting access to recent official records and government documents, in most cases due to sensitivities about privacy, and the cessation of the Papers Past newspaper resource. This thesis asks if researchers could fill this gap by drawing on tools from the fields of public history and oral history and by doing this extend and refine the theory and practice of heritage studies and heritage management.
\end{abstract}

To test this approach, I have undertaken a case study of the historic building, Ngaroma, in Wellington's Lyall Bay. The methodology I have followed involved first delving into the building's history through library and archival sources; I then conducted nine interviews with people who have had a connection to the building. The data I have gathered about both the physical and social fabric of Ngaroma and its history has built up a picture of life in the building. Memory, senses and emotion have emerged as important aspects of my findings.

In analysing the results, I have extended the established binary understanding of the physical and social fabrics of the building and developed the concept of 'numinous fabric'. In doing so I argue that we can identify the overlap between physical fabric and social fabric which can guide and inspire the way we can go about interviewing people by linking extant fabric with intangible things such as memories. This thesis finds that oral history can be used to tap into a rich source of material that adds depth and dimension to our understanding of the built heritage around us. It encourages all academics and heritage professionals researching historic buildings to undertake oral interviews as a central qualitative methodology and in doing so to bring together heritage theory and heritage management practice. 


\section{Acknowledgements}

I would like to thank both my supervisors at Victoria University of Wellington, Dr Conal McCarthy from the Museum and Heritage Studies Programme and Dr Anna Green from the Stout Research Centre, for their enthusiasm, support and guidance.

I would also like to acknowledge my interviewees without whom this project would have been impossible. To Stefania Zawada, John Gibbons, Maria Campbell, Chris Hampton, Steve Fejos, Mary Papp, Stefania Sondej, Jacqui Bisley and Carmel Fahey, sincere thanks for the generosity with which you shared your time, stories and cups of tea. It was a pleasure to interview each of you.

Thanks are due also to Wellington-based heritage practitioners Michael Kelly, Chris Cochran, Elizabeth Cox, Jamie Jacobs and Ben Schrader, who shared with me their thoughts about using oral history in the research process.

Thanks also to the team at Shut Up \& Write at Milk and Honey, veterans of the Pomodoro technique, for their good influence and solidarity. Thanks particularly to organisers Dr Lizzie Towl and Dr Sara Cotterall.

Special mention to Dr Deb Laurs from the Student Learning Centre for her insightful suggestions and patience as a sounding board throughout the whole project.

Heartfelt thanks to Ha Pham for her unwavering friendship and support.

Thanks also to my family for their unstinting belief it was all possible. 


\section{Table of Contents}

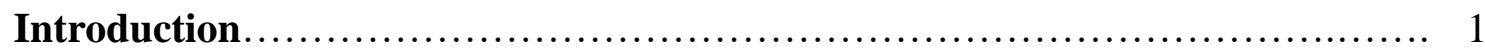

Chapter One - Background: Setting the Scene............................ 28

Chapter Two - Case Study: The Changing Fortunes of Ngaroma................. 41

Chapter Three - Analysis: The Oral Histories of Ngaroma....................... 77

Chapter Four - Discussion ........................................... 95

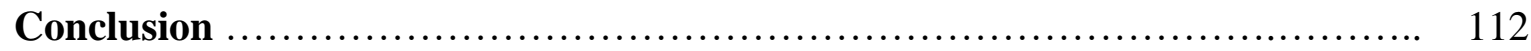

Appendix 1 - Consent to Interview Sheet.............................................. 116

Appendix 2 - NOHANZ Oral History Recording Agreement ......................... 118

Appendix 3 - Interview Questions ............................................ 120

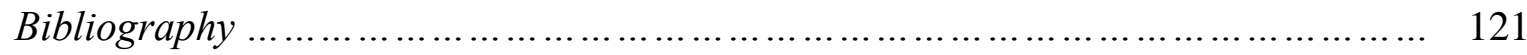




\section{Introduction}

By using a different class of records...the historian can draw up fresh maps, in which people are as prominent as places, and the two are more closely intertwined.-_Raphael Samuel ${ }^{1}$

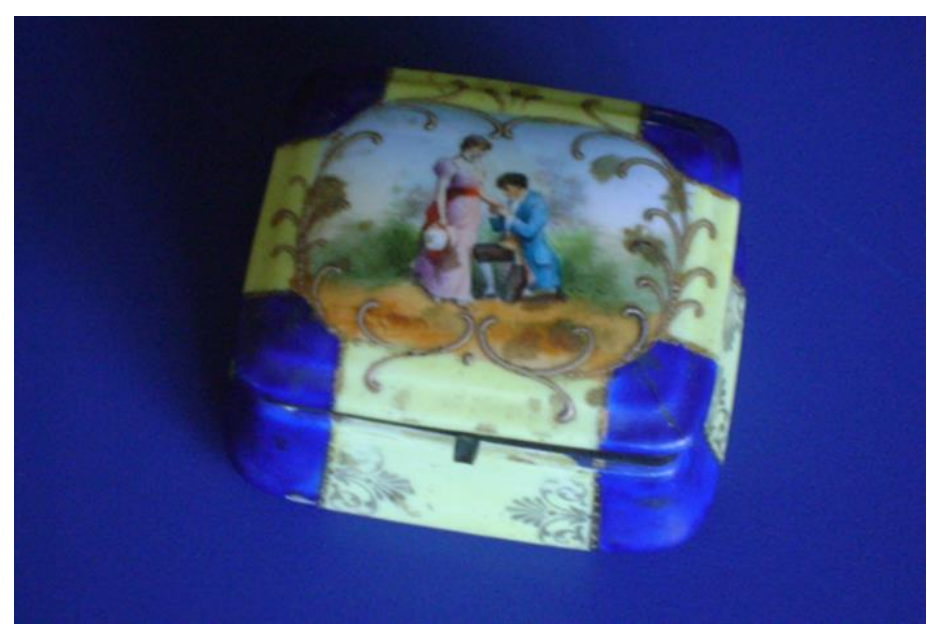

Fig. 1. Mary Papp's little box. (Photo by author)

To me, the little blue and yellow box appeared unprepossessing, but cradled in Mary Papp's capable, work-worn hands it was evidently a treasure. In the winter of 1957 she had slipped it into her pocket as she and her family were forced to abandon their home and commence a daring escape across the Hungarian border. Today the little box represents to her the life they left behind in Hungary for a journey that eventually led them half a world away to resettle in New Zealand. The box inspired a conversation about a nexus of issues, opening a window onto the importance of their new home to Mary and her family. Only oral history could articulate the significance of this physical object — an 'artefact' or 'fabric' — in order to tell the larger story of Ngaroma, the Wellington building that gave the family sanctuary. Its importance to Mary as an heirloom within her family helped me to understand just what the building has meant to those to whom it has given sanctuary and stability.

This thesis aims to challenge how built heritage is currently researched, and in doing so to develop how both heritage management practitioners and academics go about understanding and sharing the stories of the buildings and structures around us. To do this I bring the methodology of oral history into the heritage studies field and consider what it might contribute. This introduction explains the rationale behind the thesis and the subsequent

\footnotetext{
${ }^{1}$ Raphael Samuel, “Local History and Oral History,” History Workshop, no. 1 (1 April 1976): 199.
} 
literature review examines relevant theory and scholarship from the fields of heritage studies, public history and oral history. To test the methodology, I have undertaken a case study, interviewing a variety of people with connections to the building 'Ngaroma', located in Wellington's Lyall Bay. An analysis of material generated by the case study explores how useful oral history might be to the developing field of heritage studies and heritage management.

\section{Background}

In the past seven years I have worked as a contract researcher undertaking projects for heritage consultants, local councils, a conservation architect and community groups. This research has typically involved archive- and library-based primary and secondary research to determine the history and heritage values of built heritage. Projects have included not just cottages and houses but also multi-storied buildings, lighthouses, seawalls, a meteorological station, courthouses, aeroplane hangars, wharves, cemeteries, sheds, fortresses and sundry Second World War defence structures around New Zealand. Generally, this type of research establishes the reasons a structure is built; details of the construction process; information about persons involved; information about the architects; the construction method or materials; original plans; relevant newspaper articles or material relating to any opening ceremony; and details of its use and any changes, alterations, additions or decommission. With this information it is then possible to not only look at the structure to assess its history and heritage values, but also to establish how the built heritage fits into the larger narrative of New Zealand's history.

When working through this process I have often observed that there is reluctance by heritage professionals to utilise oral history interviews as a research methodology in their research process. Oral history interviews are often dismissed because they are seen as too timeconsuming, expensive, unwieldy, unnecessary, unreliable or just not 'proper history'. Yet there are often frustrating gaps in what archives and libraries hold; in particular there is often a lack of information spanning the period from the end of the Second World War to the present day. This is due to the common practice of restricting access to recent official records and government documents due to concerns about privacy sensitivities, and the cessation of 
the Papers Past website to access newspaper material because of copyright restrictions. I think that when heritage professionals overlook oral history, they may be ignoring a valuable and unique tool that could potentially illuminate this period. This project aims to explore the use of the oral interview as a legitimate methodology within the heritage field and to propose that it is a central methodological tool.

\section{Research Question}

How and why should heritage academics and heritage professionals use oral history as a central qualitative methodology when researching built heritage?

\section{Literature Review}

This literature review critically examines how the process of researching built heritage can be informed by ideas and theory from the fields of heritage studies, public history and oral history. I bring ideas from these disciplines into the field of heritage studies and in doing so expand and refine the research process for discovering and telling the stories of the buildings and structures around us.

\section{Heritage Studies}

Heritage Studies is a relatively new field which emerged in the 1980s. Although it is now accumulating a respectable body of scholarship, the existing literature concerning methodologies is not well developed. ${ }^{2}$ Graeme Davison defines heritage as 'the special name we give to those valuable features of our environment that we seek to conserve from the ravages of development and decay'. ${ }^{3}$ UNESCO's definition is 'our legacy from the past, what we live with today, and what we pass on to future generations'. ${ }^{4}$ John Schofield notes that the

\footnotetext{
${ }^{2}$ John Carman and Marie Louise Stig Sørensen, "Heritage Studies: An Outline," in Heritage Studies: Methods and Approaches, eds. Marie Louise Stig Sørensen and John Carman (London and New York: Routledge, 2009), 11.

${ }^{3}$ Graeme Davison, "Heritage: From Patrimony to Pastiche," in The Heritage Reader, ed. G. J. Graham Fairclough et al. (London and New York: Routledge, 2008), 31.

${ }^{4}$ Carman and Sørensen, "Heritage Studies: An Outline," 12.
} 
field has broadened in recent times as 'what constitutes 'heritage' has increased'. 'Heritage management', in turn, has been defined as 'approaches to and views of cultural heritage in the broadest sense'. ${ }^{6}$ In heritage studies academics generally consider the nature and management of heritage, typically bringing together scholarly frameworks linking through to an assortment of case studies to illustrate and illuminate their work. Both heritage theory and heritage practice would benefit from further investigation of methodologies. One of these methodologies, oral history, is examined in this thesis.

The publication of Heritage Studies: Methods and Approaches in 2009 challenged the fundamentals of the field. ${ }^{7}$ It emerged as a distillation of ideas from a Cambridge conference which sought to consolidate heritage studies as a field in its own right, and challenged us to reconsider the methods used and the scope and nature of heritage studies data. ${ }^{8}$ In this book a range of academics engage with a variety of approaches from legislative historiography to the intangible heritage of battlefields. Sørensen's own chapter uses oral history; she shares her experience of undertaking a project in Denmark employing oral history to understand her interviewees' attitudes to their heritage and identity. She reflects on the insights that the method allows, observing that it can be used to 'gain information about complex and abstract relations, thoughts and feelings'. ${ }^{9}$ She examines both verbal and non-verbal communication and argues for a need to be 'reflexive' in the interview process. ${ }^{10}$ This important book should inspire both academics and heritage practitioners to begin conversations that rethink methods and approaches in our field.

The oral history methodology has begun to inform heritage studies, its strengths evident in a variety of formats, including thesis, journal article, book, DVD, conservation plan and

\footnotetext{
${ }^{5}$ John Schofield, "Heritage Management, Theory and Practice," in The Heritage Reader, ed. G. J. Fairclough et al. (London and New York: Routledge, 2008), 16.

${ }^{6}$ Graham Fairclough et al., eds. "Heritage, Memory and Modernity," in The Heritage Reader, by Rodney Harrison et al. (Routledge, 2008), 7.

${ }^{7}$ Marie Louise Stig Sørensen and John Carman, eds. Heritage Studies: Methods and Approaches (London and New York: Routledge, 2009).

${ }^{8}$ Marie Louise Stig Sørensen and John Carman, "Introduction: Making the Means Transparent: Reasons and Reflections," in Heritage Studies: Methods and Approaches, eds. Marie Louise Stig Sørensen and John Carman (London and New York: Routledge, 2009), 5.

${ }^{9}$ Marie Louise Stig Sørensen, "Between the Lines and in the Margins: Interviewing People about Attitudes to Heritage and Identity," in Heritage Studies: Methods and Approaches, eds. Marie Louise Stig Sørensen and John Carman (Routledge, 2009), 164.

${ }^{10}$ Sørensen, "Between the Lines," 165.
} 
website. A closer look at this increasingly sophisticated work will follow later in the background chapter, but here I point to two articles which exemplify this body of work. In 'It's Good to Talk: Oral History, Sports History and Heritage', Fiona Skillen and Carol Osbourne set out to employ oral history as a primary source of data in their examination of British sports history. ${ }^{11}$ They describe oral history as a rich methodology that has brought a vibrancy to their heritage work. ${ }^{12}$ However, they still advise scholars to research their topics 'by triangulating oral testimony with letters, diaries and official documents' rather than depending on solely oral sources. ${ }^{13}$ In another article Mark Riley and David Harvey contribute: 'Landscape Archaeology, Heritage and the Community in Devon: An Oral History Approach', in which they observe that oral history can be 'partial, subjective, reflexive, ambiguous, sometimes contradictory and often tensioned'. ${ }^{14}$ They argue that it can be 'augmenting and supporting' to traditional approaches, rather than arguing for oral history as a stand-alone source of data. ${ }^{15}$ These two studies illustrate that oral history can be undertaken in heritage studies with valuable results, bringing dynamism and richness to widely varying and interdisciplinary projects. This thesis argues that we can do more than this and use oral history not just to augment and support, but to bring in a central new dimension to how we research heritage.

Despite this use of oral history in heritage studies, it has seldom been employed as a tool when researching built heritage. Los Angeles-based architectural conservator Benjamin Marcus challenged this when he produced a concise article entitled 'Oral History and the Documentation of Historic Sites: Recording Sense of Place'. ${ }^{16}$ He describes oral history as 'essential' but frustratingly 'often ignored as a tool for documenting historic buildings and sites' ${ }^{17} \mathrm{He}$ writes that oral history is valuable because of its ability to 'capture both personal and collective experience' and 'imagination and interpretation'. ${ }^{18}$ It also brings a 'social,

\footnotetext{
${ }^{11}$ Fiona Skillen and Carol Osborne, "It's Good to Talk: Oral History, Sports History and Heritage," The International Journal of the History of Sport 32, no. 15 (4 February 2016): 1883.

${ }^{12}$ Skillen and Osborne, "It's Good to Talk," 1884-85.

${ }^{13}$ Skillen and Osborne, 1887.

${ }^{14}$ Mark Riley and David Harvey, "Landscape Archaeology, Heritage and the Community in Devon: An Oral History Approach," International Journal of Heritage Studies 11, no. 4 (2005): 272.

${ }^{15}$ Riley and Harvey, "Landscape Archaeology," 269.

${ }^{16}$ Benjamin Marcus, "Oral History and the Documentation of Historic Sites: Recording Sense of Place," n.d., 11.

${ }^{17}$ Marcus, "Oral History and the Documentation of Historic Sites," 1.

${ }^{18}$ Marcus, 10.
} 
spiritual and ritual phenomena' to our understanding. ${ }^{19}$ He uses two case studies and encounters 'widely divergent and at times fabricated recollections' ${ }^{20}$ Yet he concludes that while oral history is often ignored it is 'essential to understanding the intangible and capturing sense of place'. ${ }^{21}$ Because it can do this, it is an 'invaluable resource' for the heritage academic or practitioner. ${ }^{22}$

Alongside these heritage studies contributions, there is an emerging field of professional literature about heritage management practice. Some refer to oral history, but most do not. The Heritage Reader strives to cover 'principles and new thinking in cultural heritage management' to establish 'a clear picture of new and older literature' in the field. ${ }^{23}$ In the 41 articles which editors Graham Fairclough, Rodney Harrison, John H. Jameson Jnr and John Schofield selected for the book, they have striven to identify key ideas and major considerations, but this 'clear picture' does not include any articles directly about the methodology of oral history in heritage studies. Yet The Heritage Reader is still influential in the heritage field and this thesis, as it contains a chapter by Australian architectural historian and heritage practitioner Semple Kerr. ${ }^{24}$ Kerr wrote The Conservation Plan, first published by the National Trust of Australia in 1982 and now accessible online. ${ }^{25}$ After six editions and 12 impressions, it continues to be useful, not least because it is a benchmark of the established way of undertaking heritage management, in particular for writing conservation plans, with an emphasis on using archival and written sources. Despite his own disinclination to leave the archive and undertake anything in the way of oral history, Kerr does encourage heritage practitioners to use "whatever techniques and sources of information are most appropriate, expeditious, and economical' in their work. ${ }^{26}$ This indicates that although the field is developing, there is still a gap in the professional literature.

\footnotetext{
${ }^{19}$ Marcus, 1.

${ }^{20}$ Marcus, 7.

${ }^{21}$ Marcus, 1.

${ }^{22}$ Marcus, 10.

${ }^{23}$ Graham Fairclough et al., eds. The Heritage Reader (London and New York: Routledge, 2008), Back cover.

${ }^{24}$ James Semple Kerr, “The Conservation Plan,” in The Heritage Reader, ed. Graham Fairclough et al.

(London and New York: Routledge, 2008).

25 James Semple Kerr, “The Conservation Plan | Australia ICOMOS,” accessed 3 August 2018, https://australia.icomos.org/publications/the-conservation-plan/.

${ }^{26}$ Kerr, "The Conservation Plan," 322.
} 
This general reluctance to utilise oral history in professional heritage practice is also reflected in the New Zealand literature. Historian Alexander Trapeznik observes that there is 'a dearth of publications dealing with heritage and public history in New Zealand'. ${ }^{27}$ He edited and published Common Ground?: Heritage and Public Places in New Zealand to bring together the contributions of an assortment of heritage practitioners and address this gap. Common Ground explores public history, heritage and place, a history of the heritage movement in New Zealand between 1890 and 2000, heritage terminology and conservation planning, heritage legislation, changing uses of historic places, reading a cultural landscape, understanding archaeological sites and assessing significance. Despite summarising the potential sources for heritage research in New Zealand, the book makes only fleeting mention of the potentials of oral history for the field.

We can see from this review of the literature that although oral history is currently not well utilised, it has begun to be cautiously employed as a methodology to inform the work of practitioners of heritage management and academics in heritage studies. As the field develops it is probable that we will begin to see oral history utilised more confidently in heritage studies literature, theory and practice. Despite this, there is currently very little professional literature in heritage studies that considers how oral history might impact on the research process for built heritage structures.

\section{Public History}

History is a well-established and diverse field which encompasses a number of broad strands; public history is one of these strands. The definition of 'public history' has been widely debated as it is 'elastic, nuanced and contentious'. ${ }^{28}$ New Zealand historian Bronwyn Dalley pins it down as 'historical work undertaken according to the research priorities, agendas or funding capacities of another party rather than being self-directed by the historian'. ${ }^{29}$ Public historians also undertake research in an academic framework. The literature within public history reflects an opening up of material and a move away from studying the elite to include

\footnotetext{
${ }^{27}$ Alexander Trapeznik, "Introduction," in Common Ground?: Heritage and Public Places in New Zealand, ed. Alexander Trapeznik (Dunedin: University of Otago Press, 2000), 9.

${ }^{28}$ Paul Ashton, "Introduction: Going Public,” Public History Review 17 (1 December 2010): 1.

29 Jock Phillips and Bronwyn Dalley, "Introduction," in Going Public: The Changing Face of New Zealand History, ed. Bronwyn Dalley and Jock Phillips (Auckland: Auckland University Press, 2001), 9.
} 
the perspectives of more diverse and 'ordinary people'. ${ }^{30}$ Oral history is well-placed to give these 'ordinary people' voice and enrich our understanding of place.

Public history today is informed and influenced by the work of British historian Raphael Samuel. Beginning in the 1970s, he led a movement which sought to democratize historymaking by undertaking 'history from below'. This 'History Workshop movement' gave voice to people who had been overlooked from the historical record. As James B. Gardner explains, Samuel challenged academics to write 'about real people, ordinary and extraordinary, dealing with real life and making choices' ${ }^{31}$ To do this, according to Toby Butler, Samuel argued that public history should open up to embrace 'a broader range of practices'. ${ }^{32}$ Since Samuel's death in 1996, public historians have begun to utilise 'different subject matter', recognising that 'other materials - outside a paper-based archive - can create value and meaning, ${ }^{33}$ New Zealand academic Kynan Gentry picks up on Samuel's work and concludes that it has 'much to offer' contemporary agendas in heritage studies. ${ }^{34}$ In particular Gentry advocates a focus on primary research and challenges 'the academic notion of what constitutes 'history', ${ }^{35}$ Increasingly, the approach now is to value 'different material' when writing public history. ${ }^{36}$ Samuel's work inspires this thesis as I bring oral history into heritage studies - bringing new, 'ordinary' voices into scholarship and challenging not just the traditional 'top-down' approach with a 'bottom-up' approach but working through a synthesis of oral history and heritage studies.

Within public history literature there is a burgeoning interest in place and the community connected to it, drawing on these sources to chart new ground. The ideas of Doreen Massey, a social scientist and geographer, are influential across several disciplines and inform the

\footnotetext{
${ }^{30}$ Thomas Cauvin, Public History: A Textbook of Practice (New York and Oxon: Routledge, 2016), 216.

${ }^{31}$ James B. Gardner, "Contested Terrain: History, Museums, and the Public," The Public Historian 26, no. 4 (2004): 16.

32 Toby Butler, "'Memoryscape': Integrating Oral History, Memory and Landscape on the River Thames," in Public History and Heritage Today: People and Their Pasts, eds. Paul Ashton and Hilda Kean (Basingstoke and New York: Palgrave Macmillan, 2008), 224.

${ }^{33}$ Hilda Kean and Paul Martin, The Public History Reader, eds. Hilda Kean and Paul Martin (Oxford and New York: Routledge, 2013), xxii.

${ }^{34}$ Kynan Gentry, “"The Pathos of Conservation': Raphael Samuel and the Politics of Heritage," International Journal of Heritage Studies 21, no. 6 (2 September 2014), 561.

35 Gentry, "Pathos of Conservation," 564.

${ }^{36}$ Butler, "“Memoryscape," 7.
} 
public history framework. She writes about place and power, not seeking to seal place into a 'neat and tidy envelope', but to 'recognise that what comes together in a place is a conjunction of many histories and places' ${ }^{37}$ Public historian Thomas Cauvin also considers community and the 'common sense of identity based on place, religion, activity, or ethnic belonging' that a place can provide. ${ }^{38}$ Public history is well-placed to benefit from an opening up of sources to see how oral history might inform scholarship about place and, in turn, built heritage and the communities associated with it.

In the New Zealand context, the literature associated with public history has progressed from uncertain beginnings in the 1930s to a more developed area of study. In 2000 it was an American, based at the New Zealand Ministry for Culture and Heritage as the Axford Fellow in Public History, who wrote a significant report which coherently outlined the field of heritage management in New Zealand at the time. Janelle Warren-Findley set out to examine the transfer of historic analysis and understanding from professional historians writing in universities and public agencies to the public interpretation of New Zealand's human heritage resources. ${ }^{39}$

Her working definition of 'heritage resources' in the New Zealand context 'includes all the elements of history created by human beings in a place over time: documents, maps, paintings, photographs, material objects, buildings, archaeological sites, and cultural landscapes'. ${ }^{40}$ It is curious that, despite this wide, rigorous and ambitious remit, her inclusive approach doesn't explicitly identify or explore oral history as a potential resource.

New Zealand public historians found a collective voice with the formation of the professional body, the Professional Historians of New Zealand Aotearoa (PHANZA) in 1994-a development recorded by Dalley and Jock Phillips in Going Public. ${ }^{41}$ They describe public history in New Zealand as a growing area with 'new roles, new media and new audiences'. ${ }^{4}$

\footnotetext{
${ }^{37}$ Butler, 225.

${ }^{38}$ Cauvin, Public History, 96.

${ }^{39}$ Janelle Warren-Findley, "Human Heritage Management in New Zealand in the Year 2000 and Beyond" 2001, 9.

${ }^{40}$ Warren-Findley, "Human Heritage Management," 9.

${ }^{41}$ Bronwyn Dalley and Jock Phillips, eds., Going Public: The Changing Face of New Zealand History (Auckland: Auckland University Press, 2001).

${ }^{42}$ Dalley and Phillips, Going Public, back cover.
} 
A consultation of the PHANZA website today shows an assortment of historians working on projects which draw heavily on archival- and library-based research approaches, but there are also a number of public historians who are utilising oral history, often to augment library- and archive-based methods. ${ }^{43}$ This indicates the diversity of historical practice today.

Ben Schrader is a public historian who is a member of PHANZA. His work investigates how history and place have shaped New Zealanders today. Both his publications, We Call it Home: A History of State Housing in New Zealand and The Big Smoke: New Zealand Cities, 1840-1920 delve into urban development in New Zealand. ${ }^{44}$ Oral history is central to his research process for We Call it Home. To tell the story of the state house, he conceptualised fabric as being either social or physical. This theoretical approach informs this thesis and provides an entry point for the theoretical considerations examined. We will return to this book in the background chapter for further inspiration and direction.

It is clear from the literature that public history is tentatively opening up to new sources and innovative approaches. Key to these changes has been the 'influence and energy' of Samuel and his ideas about conducting history from below. ${ }^{45}$ Introducing ordinary voices from people who have not traditionally made it into the historical record has fundamentally changed the discipline, and these ideas now influence how public historians think about and research place. This has been adopted in New Zealand by historians like Schrader to enrich and broaden our understanding of history.

\section{Oral History}

Oral history is a dynamic field with proliferating literature, but the heritage studies novice is well advised to begin any review of the field by consulting the well-known anthology The Oral History Reader. ${ }^{46}$ In its third edition, it brings together 27 diverse contributions from

\footnotetext{
43 “PHANZA - Professional Historians' Association of NZ," accessed 2 August 2018, http://phanza.org.nz/. ${ }^{44}$ Ben Schrader, We Call It Home: A History of State Housing in New Zealand (Auckland: Reed, 2005); Ben Schrader, The Big Smoke: New Zealand Cities, 1840-1920 (Wellington: Bridget Williams Books, 2016).

${ }^{45}$ Hilda Kean, "Public History and Raphael Samuel: A Forgotten Radical Pedagogy?," eds. Paul Ashton and Paula Hamilton, Public History Review 11 (2004): 51.

${ }^{46}$ Robert Perks and Alistair Thomson, "Critical Developments: Introduction,” in The Oral History Reader, eds. Robert Perks and Alistair Thomson (London and New York: Routledge/Taylor \& Francis Group, 2016).
} 
around the world, reflecting the intellectual energy, tensions and new frontiers of the methodology. Several of the contributions, like Alex Haley's, are indisputably modern classics of the field.$^{47}$ Editors Robert Perks and Alistair Thomson's capture current thought by identifying four paradigms of oral history's development. These are outlined below. They begin with the new popularity of oral history after the Second World War, and are influenced by changes in the 1970s, developing theoretical ideas in the 1980s and the impact of the recent and ongoing digital revolution. I have selected this explication of the shifting paradigms because it is a simple and clear for the purposes of this research.

\section{Stage One: New popularity of oral history}

Ancient historians sometimes incorporated the stories of eye-witnesses in their formal accounts of historical events, but during the 19th century, as history formed as an academic subject in itself, oral history faced marginalisation. ${ }^{48}$ However, after the Second World War there was a 'renaissance' or 'revival' of memory as a source for people's history, fuelled by the sudden and widespread availability of the portable tape recorder. ${ }^{49}$ Perks and Thomson describe this as the 'pioneer generation' of oral historians. ${ }^{50}$

The approach of these oral historians unfolded differently on either side of the Atlantic. Valerie Raleigh Yow, in her book Recording Oral History: A Guide for the Humanities and Social Sciences, charts this development in the United States, the genesis of which was Allan Nevins's 1948 project, based at Colombia University, interviewing 'white male elites' ${ }^{51}$ This approach is known in heritage studies as a 'top-down' approach, looking at the lives of important and influential people, with little interest in ordinary people. In contrast to this, the development of oral history unfolded quite differently in the United Kingdom. This is recounted in Lynn Abrams' book Oral History Theory. ${ }^{52}$ Writer, folklorist and oral historian George Ewart Evans undertook ‘bottom up history' on a famous project in which he

\footnotetext{
${ }^{47}$ Alex Haley, "Black History, Oral History and Genealogy," The Oral History Reader, eds. Robert Perks and Alistair Thomson (Oxon and New York, 2016), 22-32.

${ }^{48}$ Alistair Thomson, "Four Paradigm Transformations in Oral History," Oral History Review 34, no. 1 (2007): 51.

${ }^{49}$ Perks and Thomson, "Critical Developments: Introduction," 2.

${ }^{50}$ Perks and Thomson, 2.

${ }^{51}$ Valerie Raleigh Yow, Recording Oral History: A Guide for the Humanities and Social Sciences (Lanham: Rowman \& Littlefield, 2015), 3.

${ }^{52}$ Lynn Abrams, Oral History Theory (London and New York: Routledge, 2016).
} 
interviewed ordinary people about daily life in rural England, which he published as Ask the Fellows Who Cut the Hay. ${ }^{53}$ Today he is regarded as a 'founding father of British Oral History'. ${ }^{54}$ Although Yow's and Abrams' accounts of oral history's development follow different places and different perspectives, their subsequent discussions of more recent developments cover the same ground. Both describe a 'gradual acceptance of the usefulness and validity of oral evidence' as oral history began to develop a body of scholarship in its own right. 55

\section{Stage Two: Response to criticism}

By the late 1970s, critics of oral history were arguing that oral history was unreliable, pointing to what they saw as its weaknesses. In particular they argued that 'memory was distorted by physical deterioration and nostalgia in old age' and that this fed through to inaccurate data. ${ }^{56}$ A rebuttal of these criticisms gave impetus to the next major shift in the development of oral history. ${ }^{57}$ The counter-argument was that 'the so-called unreliability of memory was also its strength' and that the subjectivity inherent to the process, far from being a negative, actually tells us about 'the meanings of historical experience' ${ }^{58}$ Oral historians began looking at the 'relationship between past and present, between memory and personal identity, and between individual and collective memory'. ${ }^{59}$ Two key texts that were crucial to this were the works of Italians Luisa Passerini and Alessandro Portelli. Passerini published 'Work, Ideology and Consensus under Italian Fascism' in History Workshop Journal in 1979 in which she explored subjectivity. ${ }^{60}$ Perks and Thomson explain that her work celebrates 'the silences, discrepancies and idiosyncrasies of personal testimony' ${ }^{61}$ Anna Green writes that she explores 'a far more sophisticated conceptual approach with which to understand the ways in which culture and psychology influenced memory'. ${ }^{2}$ Portelli makes a similar

\footnotetext{
${ }^{53}$ George Ewart Evans, Ask the Fellows Who Cut the Hay (London: Faber, 1962).

54 Abrams, Oral History Theory, 5.

55 Thomson, "Four Paradigm Transformations in Oral History," 51.

56 Thomson, 53.

${ }^{57}$ Perks and Thomson, "Critical Developments: Introduction," 1.

${ }^{58}$ Perks and Thomson, 4.

${ }^{59}$ Perks and Thomson, 4.

${ }^{60}$ Luisa Passerini, "Work Ideology and Consensus under Italian Fascism," History Workshop, no. 8 (1 October 1979): 82.

${ }^{61}$ Perks and Thomson, "Critical Developments: Introduction," 4.

${ }^{62}$ Anna Green and Kathleen Troup, The Houses of History: A Critical Reader in Twentieth-Century History and Theory (Manchester: Manchester University Press, 1999), 232.
} 
argument in The Death of Luigi Trastulli and Other Stories ${ }^{63}$ Like Passerini, Portelli is an Italian scholar and his work is informed by his background in literature. He writes that these so-called 'weaknesses' (or 'peculiarities') are 'a resource rather than a problem'. ${ }^{64}$ Portelli explores 'not just what people did' but more broadly 'what they wanted to do, what they believed they were doing, and what they now think they did'. ${ }^{65}$

\section{Stage Three: Developing ideas}

In the late 1980s these ideas led to a rethink of the 'objectivity' of the oral historian 'as interviewer and analyst', influenced by interdisciplinarity and ideas from other fields also grappling with similar concerns. ${ }^{66}$ This led to a "transformation in perceptions about the role of the oral historian as interviewer and analyst' as oral historians shone a spotlight on the relationship between interviewers and those they were interviewing. ${ }^{67}$ Scholarship also began to look at 'the relationship between memory, narrative and identity'. ${ }^{68}$ Although this 'increasing theoretical sophistication' fuelled and informed academic discussion, it did not always feed through to those in the trenches, who carried on with projects oblivious to academic debate. ${ }^{69}$

\section{Stage Four: Digital revolution}

The fourth paradigm is the 'digital revolution', which began in the 1990s and continues today. This occurred as major new digital approaches transformed 'the ways in which we record, preserve, catalogue, interpret, share and present oral histories' ${ }^{70}$ Perks and Thomson advise us is that academics and practitioners working today need to consider 'the technical, ethical and epistemological implications' of these new technologies which give us new options for how we can create and present information. ${ }^{71}$ A salient example of this is the oral history trail that Toby Butler created to be played on mobile phones or MP3 devices, as one

\footnotetext{
${ }^{63}$ Alessandro Portelli, The Death of Luigi Trastulli, and Other Stories: Form and Meaning in Oral History (Albany: State University of New York Press, 1991).

${ }^{64}$ Perks and Thomson, "Critical Developments: Introduction," 5.

${ }^{65}$ Portelli, The Death of Luigi Trastulli, and Other Stories, 50.

${ }^{66}$ Perks and Thomson, "Critical Developments: Introduction," 7.

${ }^{67}$ Perks and Thomson, 1.

${ }^{68}$ Perks and Thomson, 8 .

${ }^{69}$ Perks and Thomson, 8 .

${ }^{70}$ Perks and Thomson, 11.

${ }^{71}$ Perks and Thomson, 12.
} 
meanders alongside the River Thames. ${ }^{72}$ An unexpected additional benefit of this digitisation process has been 'rediscovering long-forgotten, inaccessible analogue collections' ${ }^{73}$

\section{Key Debates/Ideas}

Recent literature has begun to open up and explore the complex relationship between oral history and experiences of place. Oral historian Linda Shopes writes that oral history projects are typically 'defined by locale'. ${ }^{74}$ Memories are 'rooted in places' and, in her experience, 'interviews were replete with references to streams, hills, homes, streets, stores, churches, theatres, farms' ${ }^{75}$ In Place, Writing, and Oral History Shelley Trower describes oral history as a tool 'increasingly being used to explore peoples' relationship to their surroundings, including urban environments'. ${ }^{76}$ She notes the advantages of undertaking oral history to understand localities, writing that oral history 'provides unique insight' into places. ${ }^{77}$ Yet she also cautions that 'places are not fixed, static, preservable entities, but more like processes, and also that they are not bounded territories, but are permeable - they are both shaped by and they shape other parts of the world' ${ }^{78}$ However, although the literature increasingly explores the relationship between oral history and place, it generally looks at broader locality rather than any focus on individual buildings.

Remembering: Writing Oral History, edited by academics Anna Green and Megan Hutching, brings a useful New Zealand perspective to understanding oral history and place. ${ }^{79}$ Their text is anchored in the New Zealand landscape with examples ranging from the remote Waikite Valley to a bustling Irish neighbourhood in Hamilton, but it also takes in stories that have an impact on our identity as New Zealanders_-diverse projects which include the story of an amateur dramatic society, the social issue of child abuse and an insight into the hidden lives

\footnotetext{
72 Toby Butler, “The Historical Hearing Aid: Located Oral History from the Listener's Perspective," in Place, Writing, and Voice in Oral History, ed. Shelley Trower (New York: Palgrave Macmillan, 2011), 193.

${ }^{73}$ Perks and Thomson, "Critical Developments: Introduction," 12.

${ }^{74}$ Linda Shopes, "Oral History and the Study of Communities: Problems, Paradoxes, and Possibilities," Journal Of American History 89, no. 2 (2002): 588.

${ }^{75}$ Shopes, "Oral History and the Study of Communities," 593.

${ }^{76}$ Shelley Trower, "Introduction," in Place, Writing, and Voice in Oral History, ed. Shelley Trower (New York: Palgrave Macmillan, 2011), 4.

77 Trower, "Introduction", 4.

78 Trower, 12-13.

${ }^{79}$ Anna Green and Megan Hutching, eds. Remembering: Writing Oral History (Auckland: Auckland University Press, 2004).
} 
of lesbians. Although Keenan's contribution refers to the paepae on the marae and Cathy O'Shea-Miles uses maps and buildings to explore the history of the residents and place of a neighbourhood, there is no focus on the stories of individual buildings. ${ }^{80}$

A major development in oral history was the recognition of subjectivity and its place in the interview process. Both the interviewer and interviewee bring their own subjectivity to an interview and oral historians need to be aware of this. ${ }^{81}$ Abrams writes that until the $1980 \mathrm{~s}$ academics 'pretended' that the interviewer was 'a neutral presence at the interview'. ${ }^{82}$ This changed when there was a transition from a social-scientific/structuralist interpretation to a focus on the individual. ${ }^{83}$ Oral history theory now recognises that subjectivity is 'at once inescapable and crucial to an understanding of the meanings we give our past and present' ${ }^{84}$ Yow acknowledges that subjectivity impacts on all research because 'research begins, progresses, and ends with the researcher' and this means that 'the resulting document will reflect to some extent the researcher's own assumptions' ${ }^{85}$ By the 1990 s, subjectivity began to be appreciated as contributing a 'positive element' to oral history interviews. ${ }^{86}$ It adds to the richness of data generated. There is no specific scholarship that examines how subjectivity may impact upon oral history interviews in a built heritage context, but from this development of theory we can learn to be aware of our own position and what assumptions we both bring to an interview.

Memory lies at the heart of the practice of oral history. Defining memory is unproblematicAbrams sums up collective opinion when she describes it as:

\footnotetext{
${ }^{80}$ Danny Keenan, "The Past from the Paepae: Uses of the Past in Maori Oral History," in Remembering: Writing Oral History, eds. Anna Green and Megan Hutching (Auckland: Auckland University Press, 2004), 145-151; Cathy O'Shea-Miles, "The Women of Irishtown," in Remembering: Writing Oral History, eds. Anna Green and Megan Hutching (Auckland: Auckland University Press, 2004), 77-89.

${ }^{81}$ Abrams, Oral History Theory, 54.

82 Abrams, 55.

${ }^{83}$ Abrams, 55.

${ }^{84}$ Yow, Recording Oral History, 26.

85 Yow, 7.

${ }^{86}$ Abrams, Oral History Theory, 56.
} 
a process of remembering: the calling up of images, stories, experiences and emotions from our past life, ordering them, placing them within a narrative or story and then telling them in a way that is shaped at least in part by our social and cultural context. ${ }^{87}$

But as Abrams argues, memory is not just a passive 'storehouse of facts' ${ }^{88}$ It is a narrator's interpretation of an 'active process of creation of meanings' ${ }^{89}$ It is 'complex, creative and fluid' ${ }^{90}$ Oral historians, like Portelli and Passerini, have looked at the ' interplay between what we remember, how we remember and why we remember' ${ }^{91}$ We can 'move beyond what people remember, or the content of the interviews, to why they remember, or the meaning of people's recollections' ${ }^{92}$ In the oral history context, memory is about more than the individual, it is also about 'the community, the collective, and the nation' ${ }^{93}$ For Portelli, individual and collective memories 'coexist'. ${ }^{94}$ It is the 'interplay' between them that is central to oral history. ${ }^{95}$ Michael Frisch argues that oral history is 'a powerful tool for discovering, exploring and evaluating the nature of the process of historical memory'. ${ }^{96}$ That 'errors, inventions, and myths lead us through and beyond facts to their meanings' ${ }^{97}$ Oral history has benefited from recent work in memory studies which has sought 'to link...oral history with broader public, civic, or communal memories' ${ }^{98}$

Collective memory informs our understanding, and in turn our management, of built heritage - described as the 'overlap between the individual recollections of a number of people who have shared experience and some kind of social and affective association which nurtures and supports the recreation of memory'. ${ }^{99}$ Tim Benton and Clementine Cecil write

\footnotetext{
${ }^{87}$ Abrams, 79.

88 Abrams, 99.

${ }^{89}$ Abrams, 79.

90 Abrams, 105.

${ }^{91}$ Abrams, 81.

92 Paula Hamilton and Linda Shopes, "Introduction: Building Partnerships Between Oral History and Memory Studies," in Oral History and Public Memories, eds. Paula Hamilton and Linda Shopes (Philadelphia: Temple University Press, 2008), viii-ix.

${ }_{93}$ Abrams, Oral History Theory, 79.

${ }^{94}$ Abrams, 103.

95 Abrams, 99.

${ }^{96}$ Michael Frisch, A Shared Authority: Essays on the Craft and Meaning of Oral and Public History (Albany: State University of New York Press, 1990), 188.

${ }^{97}$ Portelli, The Death of Luigi Trastulli, and Other Stories, 2.

${ }^{98}$ Hamilton and Shopes, "Introduction: Building Partnerships Between Oral History and Memory Studies," xiii.

${ }^{99}$ Tim Benton and Clementine Cecil, "Heritage and Public Memory," in Understanding Heritage and Memory, ed. Benton, Tim (Manchester and New York: Manchester University Press, 2010), 7.
} 
that 'it is an axiom of the heritage industry that buildings...enshrine memory' ${ }^{100}$ They caution us to be 'extremely sensitive to the intersection between what we as individuals cherish, in our recall of the past, and what experts consider to be valuable', describing this as a 'tough challenge'. ${ }^{101}$ This recalling of memories is a kind of intangible heritage which some scholars have used to challenge what Laurajane Smith terms the 'authorised heritage discourse' (AHD) - that is 'the various ways in which dominant groups in society impose certain values and methods on the practices of conservation' ${ }^{102}$

The literature shows that an examination of the part that sensory recollection plays in oral history and memory is the focus of fresh scholarship. It explores how senses help us make sense of the world around us. We can see that emotions and senses can be used to build a tactile and sensory understanding of the past, both of 'the everyday' and 'the exceptional'. ${ }^{103}$ The area has been influenced by what Australian oral historian Paula Hamilton identifies as the 'sensory turn' in the humanities. ${ }^{104}$ American historian Mark M. Smith writes that 'the senses are historical, and they are not universal but, rather, a product of place and, especially, time'. ${ }^{105}$ Canadian-based cultural historian Constance Classen argues that senses 'underpin cultures'. ${ }^{106}$ She suggests that we should seek to 'uncover the meaning that those smells and sounds had for people'. ${ }^{107}$ Hamilton picks up on Mark Smith's work to apply it to the oral history interview, concluding that understanding senses 'involves a conceptual shift that brings new dimensions to the interview process and its outcomes'. ${ }^{108}$ Yet sensory recollection is still described as an 'imperfectly understood area' which is likely to break new ground in oral history scholarship. ${ }^{109}$

\footnotetext{
100 Benton and Cecil, 25.

101 Benton and Cecil, 41.

102 Benton and Cecil, 7.

103 Paula Hamilton, "Oral History and the Senses," in The Oral History Reader, eds. Robert Perks and Alistair Thomson (London and New York: Routledge, 2016), 106.

${ }^{104}$ Hamilton, "Oral History and the Senses," 104.

105 Mark M. Smith, Sensing the Past: Seeing, Hearing, Smelling, Tasting, and Touching in History (California: University of California Press, 2007), 3.

${ }^{106}$ Constance Classen, Worlds of Sense: Exploring the Senses in History and Across Cultures (London and New York: Routledge, 1993), 7.

${ }^{107}$ Hamilton, "Oral History and the Senses," 106.

${ }^{108}$ Hamilton, 114.

${ }^{109}$ Hamilton, 106
} 
The topic of emotion in oral history has also generated increasing literature about the part it plays in the oral history interview. In 2004 Green was one of the scholars at the forefront of these developments when she identified that emotion is 'intrinsic to storytelling' conveyed 'through vocabulary, verbal expression and tone, or humour'. ${ }^{110}$ Sørensen also is interested in the 'roles emotions and empathy play in this [interview] process'. ${ }^{111}$ Orality, such as the tone of voice and the speed of narration, is an important part of how emotion is conveyed. It is a challenge not to lose this through the process of transcription.

\section{Numinous Fabric}

When researching the history of built heritage, academics and practitioners often focus on the extant physical fabric of a structure. They consult original plans and photographs and carry out site visits to establish what is the original fabric and identify changes and alterations to that fabric. This approach is particularly evident in conservation plans. However, recent writing reflects an increasing sophistication in this approach. Particularly relevant is Schrader's new approach to built heritage, in We Call it Home, in which he conceptualises his understanding of the fabric of a building as not just physical fabric, but also the social fabric of its attendant stories. ${ }^{112} \mathrm{He}$ uses oral history to capture both, in order to tell the stories of state housing in New Zealand.

This thesis further explores how oral interviews about built heritage can be informed and guided by an approach that focuses on the fabric of a structure. Although the term 'numinous fabric' has not been used in the context of heritage studies before, it is well suited to the approach taken in this thesis and the idea will be later developed and extended in Chapter Four. Here we examine the literature articulating the relationship between material heritage and memory to see how it might inform an oral history approach to researching built heritage and explore the concept of 'numinous' as it relates to the sociocultural meanings attached to heritage.

\footnotetext{
${ }^{110}$ Anna Green, “'Unpacking' the Stories," in Remembering: Writing Oral History, eds. Anna Green and Megan Hutching (Auckland: Auckland University Press, 2004), 17.

${ }^{111}$ Sørensen, "Between the Lines and in the Margins," 174.

${ }^{112}$ Schrader, We Call It Home, 11.
} 
The word 'numen' is not new; the literature shows that it has undergone several changes in semantics and application. Catherine Cameron and John Gatehead explain that the term was originally used by German academic Rudolf Otto, who appropriated and repurposed it from Latin, where it has been variously translated as 'a nod or beckoning from the gods' or 'a spiritual force or influence identified with a natural object, phenomenon, or place'. ${ }^{113}$ Otto used it in 1917 for his book The Idea of the Holy, when he applied the word to the scholarship of religious philosophy to describe 'a religious emotion or experience that can be awakened by the presence of something holy'. ${ }^{114}$

In 1993 the term was first used in the field of public history by Rachel Maines and James Glynn, who describe material 'inhabited by a numen or spirit that calls forth in many of us a reaction of awe and reverence'. ${ }^{115}$ They took this idea out of a specifically religious usage and applied it to artefacts with 'psychological rather than material' significance. ${ }^{116}$ They brought this understanding of numinous objects into the museum by applying the considerations of numinous objects to collection policy. They focused on objects which 'tell stories' and which are 'the stuff of social and intellectual history' ${ }^{117}$ Their working definition of numinous objects still stands today as:

examples of material culture that have acquired sufficient perceived significance by association to merit preservation in the public trust. They are objects we collect and preserve, not for what they may reveal to us as material documents, or for any visible aesthetic quality, but for their association, real or imagined, with some person, place or event endowed with special sociocultural magic. ${ }^{118}$

To Maines and Glynn, the word describes 'the interaction of emotions, ideas, and beliefs with material culture'. ${ }^{119}$ The significance of these objects is 'psychological rather than material'. ${ }^{120}$ Their article considers a wide assortment of numinous objects, everything from a

\footnotetext{
${ }^{113}$ Catherine M. Cameron and John B. Gatewood, "Excursions into the Un-Remembered Past: What People Want from Visits to Historical Sites," The Public Historian 22, no. 3 (2000): 109.

${ }^{114}$ Cameron and Gatewood, "Excursions into the Un-Remembered Past," 109.

115 Rachel P. Maines and James J. Glynn, "Numinous Objects,” The Public Historian 15, no. 1 (1 January 1993): 9.

116 Maines and Glynn, "Numinous Objects," 9.

${ }^{117}$ Maines and Glynn, 10.

118 Maines and Glynn, 10.

${ }^{119}$ Maines and Glynn, 10.

${ }^{120}$ Maines and Glynn, 9.
} 
pressed carnation from a school prom to the aircraft Enola Gay. ${ }^{121}$ Although the focus is on objects, they suggest that it can also be applied to place. ${ }^{122}$ Place is also explored by Cameron and Gatehead who call those seeking a 'meaningful connection' at heritage sites 'numenseekers'. ${ }^{123}$

In 2016 Lindsey Freeman, Benjamin Nienass and Rachel Daniell, working in memory studies, also explored ideas about objects and memory and although they don't use the word 'numinous' their ideas chart a similar trajectory. They argue that it is important to 'break down the artificial binaries between mind and matter'. ${ }^{124}$ They call this 'mnemonic assemblages' and describe it thus: 'In order to think through our pasts, as they are entangled with our presents, we must examine the intersections of sensation, experience, and meaning that arise through our interactions with material forms'. ${ }^{125}$ Talking about material, they argue that we should 'sift through the capharnaum of the everyday and the extraordinary', in other words we should consider a wide assortment of extant fabric in order to identify and understand 'the points where matter meets memory'. ${ }^{126}$ They see this as a way to 're-vitalize and re-examine long-held notions about the relationship between objects and the past'. ${ }^{127}$ They conclude that our pasts are 'entangled with our presents', but that 'memories are sparked and narrated through things'. ${ }^{128}$

In the context of this thesis, these ideas are useful as I argue for the importance of engaging with things (or fabric) in a way that can inform, inspire and guide the interview process and increase our understanding of a structure. The phenomenological aspect of this approach is appropriate for the direction and argument of this thesis. These ideas and considerations will be revisited and extended in Chapter Four.

\footnotetext{
${ }^{121}$ Maines and Glynn, 11.

${ }^{122}$ Maines and Glynn, 10.

${ }^{123}$ Cameron and Gatewood, "Excursions into the Un-Remembered Past," 55.

${ }^{124}$ Lindsey A. Freeman, Benjamin Nienass, and Rachel Daniell, "Memory | Materiality | Sensuality," Memory Studies 9, no. 1 (2016): 3.

${ }^{125}$ Freeman, Nienass, and Daniell, "Memory | Materiality | Sensuality," 4.

${ }^{126}$ Freeman, Nienass, and Daniell, 4.

${ }^{127}$ Freeman, Nienass, and Daniell, 5.

${ }^{128}$ Freeman, Nienass, and Daniell, 4.
} 
Taken together, literature from the three fields of heritage studies, public history and oral history establishes a platform for this thesis. From heritage studies comes the challenge issued by Sørensen and Carman to reconsider our methods and approaches. From public history we can learn from Samuel and his attempt to give voice to ordinary people. From oral history we can see the interview gaining authority and increasing recognition as a useful tool. We are informed by burgeoning scholarship engaging with place, subjectivity, memory, senses and emotion. Academics like Schrader can inspire our approach to how we think about the fabric of built heritage, and I would challenge this with a new 'numinous fabric' approach. Yet there is very little literature that considers how oral history might inform the research process for investigating built heritage. In my view, we might use numinous fabric as an idea that could help us connect with stories of built heritage and extend current theory to do this. If we can encourage heritage academics and practitioners to undertake more oral history, it could encourage a richer and more rounded understanding of the built heritage around us. In doing this, this thesis contributes to and extends the field of heritage studies.

\section{Research Design}

This thesis examines the question of how and why heritage academics and heritage practitioners should use oral history as a methodology when they research built heritage. It fills a gap in the research process that exists because of a dearth of material relating to more recent history. The literature review follows an opening up of types of material across the fields of heritage studies, public history and oral history. It also indicates the range of interdisciplinary studies which have benefited from undertaking an oral history approach and been rewarded by the richness and insight that oral history can provide. This thesis investigates built heritage in particular, with a central case study of a historic building. The approach will be mixed-methods, as it includes library- and archive-based research and oral history interviews. In doing this I seek to establish the efficacy of using oral history in the context of built heritage research, with an overall approach that is qualitative, phenomenological, empirically-based and inductive, and which encompasses personal observation and participants' perspectives and memories. 


\section{Case Study}

At the core of this thesis is a case study which explores the history of a building, Ngaroma, at 112 Queens Drive in Wellington's Lyall Bay. Case studies are widely used in social sciences; they are a "spotlight" approach which sit within the qualitative method. They aim to 'illuminate the general by looking at the particular' and discover 'insights to be gained from looking at the individual case that can have wider implications'. ${ }^{129}$ The type of case study is a 'test-site for theory', as it is trying to establish if oral history should be used as a central methodology when researching built heritage. ${ }^{130}$ The strengths of oral history studies are that they can 'unravel the complexities of a given situation' and 'study things in detail'. ${ }^{131}$ By looking at the history of Ngaroma as a case study, I can draw conclusions about how we might utilise oral history when we research built heritage.

For a number of practical reasons, Ngaroma is a suitable case study. It has an architectural style unusual in New Zealand, a dynamic history and is conveniently located in Wellington's Lyall Bay. Preliminary research indicated that there was a wealth of archival and library material relating to the building. Most importantly, its varied past meant that there were several communities associated with the building whom I could approach to interview. These potential interviewees had not, to my knowledge, ever been interviewed for an academic project about their memories of Ngaroma, and no substantial publication solely about the building exists. The final deciding factor in the feasibility of using this building as a case study was that access to the building was granted by the current owners.

Case studies have limitations. Martyn Denscombe writes that the approach can be 'ill-suited to analyses or evaluations', however he agrees that this disadvantage can be mitigated by a 'careful attention to detail and rigour' in the process. ${ }^{132}$ Another potential problem is that there may be periods of time that will not be represented by interviewees due to reluctance of people to be interviewed. Many of the people who would have made excellent interviewees, for example the original generation of the Hope Gibbons family who lived at the house, have

\footnotetext{
${ }^{129}$ Martyn Denscombe, The Good Research Guide: For Small-Scale Social Research Projects (Maidenhead: McGraw-Hill/Open University Press, 2010), 53.

${ }^{130}$ Denscombe, The Good Research Guide, 58.

${ }^{131}$ Denscombe, 53.

132 Denscombe, 63.
} 
passed away. This is a reality of the case study and oral history approach. Despite this, I decided that using Ngaroma as a case study was appropriate to explore the research question posited by this thesis.

\section{Methodology}

This research employs a mixed-methods, qualitative approach. The strength of a mixedmethod methodology is that it allows me to 'compare alternative perspectives on a phenomenon', in this case Ngaroma's history. ${ }^{133}$ A significant part of the thesis is a case study of the building chosen to test the methodology of using oral history as a central research tool in built heritage. The methods used for this thesis are:

1. Library-based research

2. Archive-based research

3. Oral interviews

The first method was library-based research. This identifies published and unpublished material about the chosen case study building, which is held at the Victoria University of Wellington Library, the Wellington City Library, the National Library and the Alexander Turnbull Library. Material includes published, unpublished and online sources, such as books, photos, newspapers and magazines and journal articles. As David E. Gray identifies, the strength of using these types of sources of evidence is that they are stable, unobtrusive and have broad coverage. ${ }^{134}$ But Denscombe cautions that the validity of these sources should not be 'taken for granted' at face value. ${ }^{135}$ This method is appropriate because it is the established way of undertaking heritage studies research, and therefore establishes the basic foundation on which the case study is built.

The second method is further research into Ngaroma by sourcing material at archives in Wellington. Material includes original plans of the house and gardens, images, documents and films. These are held at the Museum of New Zealand Te Papa Tongarewa, Auckland War

\footnotetext{
${ }^{133}$ Denscombe, 6.

${ }^{134}$ David E. Gray, Doing Research in the Real World (Los Angeles: SAGE, 2009), 259.

${ }^{135}$ Denscombe, The Good Research Guide, 221.
} 
Memorial Museum, Wellington City Council Archive, Archives New Zealand, the Wellington Archdiocesan Catholic Archive, Nga Taonga Sound \& Vision, Sisters of Compassion Archive and Heritage New Zealand. Archive-based research has many of the same advantages and issues as library-based research. In addition to these, there were access issues with fragile, damaged or embargoed material.

The third method is the conducting of qualitative semi-structured oral interviews with nine interviewees about their memories of their connection to, or association with, Ngaroma. ${ }^{136}$ As Gray writes, the strength of oral history is that interviews are targeted, as they can focus directly on a topic and they can be insightful, by providing 'illuminating data' ${ }^{137}$ As Denscombe notes, 'subjects can be probed, issues pursued and lines of investigation followed'. ${ }^{138}$ Yet Gray cautions us to be aware of potential problems such as 'poorly constructed questions', 'response bias', 'inaccuracies due to poor recall' and concerns about whether the interviewee is merely providing what the interviewer wants to hear. ${ }^{139}$ At a later stage of the research, I contacted five Wellington-based heritage practitioners and questioned them about their attitude to, and experience of, undertaking oral history as part of their research process.

\section{Sampling, Analysis and Site Visit}

Interviewees were identified and approached through a 'snowball sampling' strategy — when 'participants refer the researcher on to other potential participants' ${ }^{140}$ I began by contacting the Polish Association of New Zealand, the Society of St Vincent de Paul in Wellington, the Archdiocese of Wellington Catholic Archive, Sisters of the Good Shepherd in Australia and various further contacts suggested or provided by these groups. Focus was on finding interviewees located in Wellington who had a connection to the building. These interviewees are drawn from the following groups: descendants of the Hope Gibbons family, women who lived at the Polish Girls' Hostel as girls (1947-1958), people associated with the Society of St Vincent de Paul who ran Ngaroma as a hostel for refugees admitted to New Zealand by the

\footnotetext{
${ }^{136}$ Oral interviews held by the author.

${ }^{137}$ Gray, Doing Research in the Real World, 259.

${ }^{138}$ Denscombe, The Good Research Guide, 192.

${ }^{139}$ Gray, Doing Research in the Real World, 259.

${ }^{140}$ Denscombe, The Good Research Guide, 37.
} 
government (1958-1967), those associated with Ngaroma when it was administered by the Sisters of the Good Shepherd as a hostel for working girls (1967-1969), anyone associated with the papal nunciature (1969-2015), and staff, neighbours, visitors or employees from any of these periods.

With nine people drawn from these groups I conducted 30- to 90-minute, one-on-one, semistructured, oral interviews. Each interviewee was given an information sheet explaining the project prior to agreeing to be interviewed. The interviews were undertaken in accordance with Victoria University of Wellington's ethical guidelines, with informed consent obtained from all interviewees. (See appendix for consent to interview sheet and NOHANZ Oral History Agreement). The interviews were prompted by a list of topics and open-ended questions. (See the appendix for the list of questions.). Questions were tailored to the different interviewees depending on their connection to the building. These interviews were recorded. To some extent the interviews were directed by the interviewees as they focused on the memories they considered most pertinent or entertaining. The questions included general biographical information, questions about their memories of Ngaroma and their time there.

As Sørensen advises, I strove to be 'collaborative' and be aware of my own subjectivity in the process. ${ }^{141}$ I was influenced by Frisch, who coined the phrase 'shared authority' to describe the relationship between interviewer and interviewee. ${ }^{142}$ The interview process exploring the stories of buildings is quite different from most interview situations which typically chart a person's life story chronologically. Recalling life in a building has no particular shape to it. As literary critic Robert Fulford notes, 'the world is not a place of beginnings and endings and middles, a place of coherence' and this is equally applicable to conversations about buildings. ${ }^{143}$ To be aware of how subjectivity influences the interviews, it was important to allow the interviewees freedom to talk widely and thematically about what they wanted to talk about, rather than trying to control the interview so that it might unfold sequentially along the lines of the previously established interview questions.

\footnotetext{
${ }^{141}$ Sørensen, "Between the Lines and in the Margins," 176.

${ }^{142}$ Frisch, A Shared Authority, xx.

143 Yow, Recording Oral History, 24.
} 
Snowball sampling is a valid and effective way of finding interviewees. This method allowed me to tap into an existing network of families, friends and communities with a connection to each other and the house. It was a particularly valuable way to identify community leaders or unofficial archivists who have kept a record or collection of artefacts, photos or other documents and paraphernalia. In this case study, the richest trove proved to be Józef and Stefania Zawada's photographic collection of life at Ngaroma when it was run as a Polish hostel between 1947 and 1958. The disadvantage of snowball sampling is that if you tap into one group or family within the larger pool you may miss out on other sub-groups. Despite this, I think that snowball sampling is still the most practical and appropriate way of identifying potential interviewees when researching built heritage.

Field notes, a tool for noting observations often used in qualitative fieldwork in ethnography, proved to be a helpful way of keeping track of my impressions of the interviews. Also, for noting down things not recorded - comments made before and after the interviews, body language and facial expressions and other nonverbal communications. Stefania Sondej has a strong Polish accent and a surprisingly girlish giggle, and she grasped my hand when she wanted to emphasise something. These were all things worth noting down. I found it disrespectful to, and distracting for, my interviewees to see me scribbling away during an interview, so I limited it to a useful way of 'debriefing' by jotting down notes after the interview. The field notes became a practical way of keeping a log of the project. They helped me to record the sources of newspaper articles, photos and business cards that were given to me during and after interviews.

I undertook data analysis of the nine interviews. Sections were transcribed, using direct quotes for the most relevant material. Themes that were 'obvious' or 'recurring', and issues and concepts were identified. ${ }^{144}$ This built on material mined through the methods of libraryand archive-based research to establish what oral history could further bring to my understanding of the building. I interpreted the findings to see beyond the individual interviews to understand the larger narrative for the history of Ngaroma.

${ }^{144}$ Denscombe, The Good Research Guide, 240. 
A site visit was undertaken to Ngaroma at 112 Queens Drive in Wellington's Lyall Bay. This allowed me to look at the physical fabric of both the interior and exterior of the house, and its setting in its extensive grounds overlooking Lyall Bay. This was important because it gave me insight into, and familiarity with, the house and its contents which helped me to understand the building itself, and in turn the people's memories of it. Using copies of the original 1926 plans I was able to establish the original usage of the rooms.

\section{Thesis Outline}

This introduction has reviewed relevant literature to examine how scholarship and theory from the fields of heritage studies, public history and oral history might be used to inform my understanding of using oral history for researching built heritage. It establishes the research design and identifies research methodologies for the case study. In this thesis, Chapter One establishes the background and setting for the case study of the building Ngaroma. It first looks at the New Zealand regulatory environment. It then examines examples of work which use oral history to research built heritage both in New Zealand and internationally. It next considers the current practice and perspectives of Wellington-based heritage professionals. It also provides background information for the case study building and introduces the nine interviewees. The second chapter explores the history of the case study building, Ngaroma, from material gathered from library and archival sources. The third chapter looks thematically and analytically at material gathered from interviews about Ngaroma's history. The fourth chapter is an analysis and discussion about using oral history as a methodology for researching built heritage. The conclusion summarises the findings of the research and makes suggestions and recommendations for students, academics and heritage management practitioners. 


\section{Chapter One - Background: Setting the Scene}

Ngāroma. - A Māori word meaning 'stream' or 'current'.

\section{Introduction}

The previous section explores the rationale for this project, reviews relevant literature in the field, and establishes the research questions, design and methodology. This first chapter focuses on establishing the background and setting for the case study by situating Ngaroma in the context of Wellington heritage management. There are a number of agencies that intersect in this scene: they influence and guide the heritage professionals who work locally. We look at a broad overview of the regulatory environment, examine work produced in various formats by both international and Wellington-based heritage professionals, before looking at the professionals themselves and appraising their attitudes to undertaking oral history. This chapter sets up the Ngaroma case study, which seeks to explore if oral history can be used as a methodology (or tool) to help researchers understand the history of built heritage.

\section{Regulatory Environment}

Heritage management in New Zealand occurs within a legislative framework, which is influenced and shaped by a number of agencies and organisations. Heritage New Zealand, the Department of Conservation, the Ministry for Culture and Heritage, the Wellington City Council and ICOMOS provide the backdrop to heritage management in Wellington, and thus influence and provide context for my case study building in Wellington, the house known as Ngaroma.

\section{Heritage New Zealand}

Heritage New Zealand Pouhere Taonga is an autonomous Crown entity that works to identify and protect sites and buildings of heritage value around New Zealand. It was set up under the Historic Places Act 1954 and was originally known as the New Zealand Historic Places Trust. It was renamed Heritage New Zealand under new legislation stipulated in the Heritage New Zealand Pouhere Taonga Act 2014. The organisation maintains the New Zealand 
Heritage List Rārangi Kōrero and 43 historic properties with significant heritage value throughout New Zealand. It is funded through the Ministry for Culture and Heritage. ${ }^{1}$

\section{Department of Conservation}

The Department of Conservation Te Papa Atawhai is a government agency charged with the conservation of New Zealand's natural and historic heritage. The agency's focus is mainly environmental, but it also manages a variety of New Zealand's archaeological and heritage sites, seeking to preserve and protect them. It cares for 'the places that shaped New Zealand's history and tell our stories'. ${ }^{2}$

\section{Ministry for Culture and Heritage}

The Ministry for Culture and Heritage Manatū Taonga was established in New Zealand in 2000 when the Ministry of Cultural Affairs was combined with the history and heritage sections of the Department of Internal Affairs, some parts of the Department of Conservation and the Ministry of Commerce. The Ministry for Culture and Heritage advises the government on arts and culture, heritage, broadcasting and sport and recreation, and maintains the web-based Te Ara: The Encyclopedia of New Zealand and the Dictionary of New Zealand Biography. ${ }^{3}$

\section{Wellington City Council}

Protective mechanisms for managing historic heritage in Wellington are administered by the Wellington City Council through The Wellington City District Plan policies and heritage listings, as occurs similarly in all New Zealand districts. The Wellington City Council is substantially informed and guided by the Resource Management Act 1991 and their 2010 Heritage Policy. ${ }^{4}$

\footnotetext{
1 "Heritage New Zealand," accessed 12 August 2018, http://www.heritage.org.nz/.

${ }^{2}$ New Zealand Department of Conservation (DOC), "Department of Conservation," accessed 12 August 2018, https://www.doc.govt.nz/.

3 “Homepage | Ministry for Culture and Heritage," accessed 12 August 2018, https://mch.govt.nz/.

4 “Wellington City Council," accessed 12 August 2018, https://wellington.govt.nz/.
} 


\section{ICOMOS}

The International Council on Monuments and Sites is a non-governmental international organisation dedicated to the conservation of the world's monuments and sites. It was founded in 1965 as a result of the Venice Charter of 1964. It provides advice to UNESCO on World Heritage Sites. ICOMOS New Zealand was established in 1987 and the ICOMOS Charter for the Conservation of Places of Cultural Heritage Value has been hugely influential on New Zealand heritage professionals as a guiding document in their professional work. ${ }^{5}$ Wellington heritage professionals routinely include a summary of this charter as an appendix in their conservation plans.

\section{Pertinent Legislation}

As Greg Vossler notes, 'there currently exists within the New Zealand legislative landscape a myriad of statutes that impinge on the protection and management of our historic heritage' ${ }^{6}$ Some are well-known, others more obscure. For this Wellington-based case study there are several which are most relevant to built heritage management in Wellington. They are the Conservation Act 1987, the Resource Management Act 1991, the Local Government Act 2002, the Building Act 2004, Heritage New Zealand Pouhere Taonga Act 2014 and the Buildings Amendment Act 2016. They are the mechanisms for how heritage is managed in New Zealand, and all practising professionals in the heritage studies field have a working knowledge of this legislation.

\section{Oral History and Built Heritage}

Academics, heritage professionals and heritage enthusiasts have produced work using oral history as a methodology to investigate built heritage both internationally and in Wellington. In recent years, material has proliferated in a variety of formats and the work explored here has been produced as a thesis, journal article, book, DVD, conservation plan and website.

\footnotetext{
${ }^{5}$ Gavin McLean, “Where Sheep May Not Safely Graze: A Brief History of New Zealand's Heritage Movement 1890-2000," in Common Ground?: Heritage and Public Places in New Zealand, ed. Alexander Trapeznik (Dunedin: University of Otago Press, 2000), 42.

${ }^{6}$ Greg Vossler, "Sense or Nonsense?: Heritage Legislation in Perspective," in Common Ground?: Heritage and Public Places in New Zealand, ed. Alexander Trapeznik (Dunedin: University of Otago Press, 2000), 68.
} 


\section{International}

- Last One In: Community, Conflict and Preservation of McCarren Park Pool, was a thesis written by Benjamin Marcus and submitted to the Graduate School of Architecture, Planning and Preservation at Colombia University in New York. He used a public swimming pool as a case study to explore how oral history, along with architectural analysis, can be used to document the history of a physical structure. He touches on the history of oral history, and includes a very brief literature review and the material generated by ten interviews, but most of the thesis is an exhaustive history of the pool itself aided by images, plans and photographs. ${ }^{7}$

- 'Moving Beyond the Walls: The Oral History of the Ottoman Fortress Villages of Seddülbahir and Kumkale' by Işıl Cerem Cenker and Lucienne Thys-Şenocak appears in Oral History and Public Memories, a book edited by experts in the oral history field, Paula Hamilton and Linda Shopes. ${ }^{8}$ The chapter recounts a three-year oral history project which was instigated by Koç University and Istanbul Technical University, looking at the history of fortresses at Seddülbahir and Kumkale, two Turkish villages situated at the entrance to the Dardanelles. Both fortresses were built by the mother of Ottoman Sultan Mehmed IV, Hadice Turhan Sultan, in the 17th century. The scholars undertook an examination of both textual and oral sources. In doing this they encountered 'the kinds of disjunctures that exist among official records, representation, and the local consciousness and identity that have evolved at these two historical sites', and also 'how divergent meanings and memories that are ascribed to a cultural landscape and historical site can be brought together as enriching rather than competing factors' ${ }^{9}$ Of note to this project is that even though exhaustive textual material existed in archives, the project still encompassed and benefited from an oral history approach.

\footnotetext{
${ }^{7}$ Benjamin Marcus, "Last One In: Community, Conflict and the Preservation of McCarren Park Pool" (Colombia University, 2006).

${ }^{8}$ Iş1l Cerem Cenker and Lucienne Thys-Şenocak, "Moving Beyond the Walls: The Oral History of the Ottoman Fortress Villages of Seddulbahir and Kumkale," in Oral History and Public Memories, eds. Paula Hamilton and Linda Shopes (Philadelphia: Temple University Press, 2008), 65-86.

${ }^{9}$ Cenker and Thys-Şenocak, "Moving Beyond the Walls," 66.
} 
- 'The Co-construction of Spatial Memory: Enriching Architectural Histories of "Ordinary" Buildings' was published in Fabrications: The Journal of the Society of Architectural Historians, Australia and New Zealand, by Jesse Adams Stein. ${ }^{10}$ She interviewed 31 former employees of at the New South Wales Government Printing Office in Sydney about aspects of life in the building, focussing on their memories of 'technological change and working life'. ${ }^{11}$ She approached the project from the perspectives of oral history and architectural history and discovered 'a wealth of spatial and architectural content embedded within the workers' recollections' ${ }^{12}$ Her article is 'a call for attention to the richness of content contained within factory workers' memories of the buildings in which they worked' ${ }^{13}$ The article is an elegant example of how more traditional sources can be complemented and enhanced by material gleaned from oral sources.

- Memory, Oral History and Conservation at Robben Island's Bluestone Quarry' in the South African Historical Journal, is an article written by Mwayi Lusaka, a Malawian historian working at the University of the Western Cape.${ }^{14}$ He used oral history to explore the history of a quarry located on Robben Island. The island served as a political prison for some of those incarcerated for opposing apartheid between 1961 and 1991, and it has more recently become a celebrated 'beacon of reconciliation' to the South African people. ${ }^{15}$ Lusaka looks at 'memory via oral history' in landscape interpretation and heritage management. ${ }^{16} \mathrm{He}$ interviewed ex-prisoners who had laboured on the quarry's stone wall in the 1960s and concludes that their memories 'enhanced the understanding and appreciation of symbolic meanings of suffering and triumph that the site embodied'. ${ }^{17}$

\footnotetext{
${ }^{10}$ Jesse Adams Stein, "The Co-Construction of Spatial Memory: Enriching Architectural Histories of 'Ordinary' Buildings," Fabrications: The Journal of the Society of Architectural Historians, Australia and New Zealand 24, no. 2 (3 July 2014): 178-197.

${ }^{11}$ Stein, " The Co-Construction of Spatial Memory," 180.

${ }^{12}$ Stein, 179.

${ }^{13}$ Stein, 179.

${ }^{14}$ Mwayi Lusaka, "Memory, Oral History and Conservation at Robben Island's Bluestone Quarry," South African Historical Journal 69, no. 4 (2 October 2017): 583-597.

${ }^{15}$ Lusaka, "Memory, Oral History and Conservation at Robben Island's Bluestone Quarry," 587.

${ }^{16}$ Stein, "The Co-Construction of Spatial Memory," 587.

${ }^{17}$ Lusaka, "Memory, Oral History and Conservation at Robben Island's Bluestone Quarry," 584.
} 


\section{New Zealand}

- We Call It Home: A History of State Housing in New Zealand was written by Wellington urban historian Ben Schrader. ${ }^{18}$ It explores the history and stories of the last century of New Zealand state house tenants, architects and policy makers. Schrader interviewed 16 people representing a cross section of respondents and describes oral history as 'a vital aspect of the book' because there was 'no other way to get the type of information...needed'. ${ }^{19} \mathrm{He}$ suggests that a home has both physical and social fabric. Physical fabric is the material of the house while social fabric is 'the intangible patchwork of memories, emotions and experiences' ${ }^{20}$ He usefully clarifies the difference: 'while we might see an empty bath, someone who lived in the house might remember the bath filled with children splashing and having fun' ${ }^{21}$

- In 2009 Marie Russell created a DVD called A Place to Stay, telling the story of the Salisbury Garden Court Heritage Area in Wellington's suburb of Wadestown. ${ }^{22}$ This community comprises 16 houses built between 1929 and 1930 on the steep, bushcloaked Tinakori hillside, clustered around a shared common tennis court with primarily pedestrian-only access. The DVD looks at urban design and the 'Garden City' architectural ideas which informed the design of this urban community. The film follows the social history, from the 1950s when it was mainly a Polish enclave, to the 1970s when it was a hippy commune and talks to the largely tight-knit community that is still there today. The producers of this DVD interview a range of people who claim some connection to the buildings.

- In 2004 Wellington conservation architect Chris Cochran completed St Joseph's Church \& Convent Conservation Plan for the church and adjacent convent building located beside the Whanganui River at the settlement of Jerusalem Hiruhārama. ${ }^{23}$ Like all thorough conservation plans it details the history, provides a description of significance, identifies work required and suggests maintenance. A central part of the

\footnotetext{
${ }^{18}$ Schrader, We Call It Home.

${ }^{19}$ Schrader, 10.

${ }^{20}$ Schrader, 11.

${ }^{21}$ Schrader, 11.

${ }^{22}$ Robin Brew et al., A Place to Stay a Film about Salisbury Garden Court (Wellington: Community Media Trust, 2009).

${ }^{23}$ Chris Cochran, "St Joseph's Church \& Convent Conservation Plan,” 2004.
} 
plan includes an extensive history written by Wellington historian Jessie Munro. Munro is an expert on the history of the Sisters of Compassion and their founder Suzanne Aubert, having published to acclaim The Story of Suzanne Aubert in $1996 .{ }^{24}$ Her research for the conservation plan relies heavily on oral history: she interviewed Sister of Compassion Bernadette Mary Wrack in a series of unrecorded interviews for this purpose. Wrack reflects on her life at Jerusalem in the 1950s. Several other sisters, including Sister Josephine Caulton also make contributions. Munro writes about life before the church and convent were built; the story of the church and convent (1891-1904); the life of the buildings (1904-1969); the convent in the 1950s; and the period after the school was closed and an envoi. The length, depth and heavy use of oral history was beyond Cochran's expectations, but after some thought he eventually decided to include Jessie Munro's chapter in its entirety and now believes this was the right decision. ${ }^{25}$ In the mid-2000s both the church and convent were renovated according to these plans.

- 'Life at the Rotherham House in the 1950s and 1960s', was published by Julia Gatley in Fabrications: The Journal of the Society of Architectural Historians, Australia and New Zealand. ${ }^{26}$ Gatley describes the ownership, occupancy and use of Rotherham House, a modern house designed by the Group Construction Company/Group Architects, built in 1950-51 and located at Auckland's Stanley Bay. The article starts by looking at published and unpublished sources, then looks to oral history for 'elaboration and enrichment' of the story of the house. ${ }^{27}$ These comprise 'memory and personal perceptions, thoughts, feelings and insights'. ${ }^{28}$ The rather haphazard interview process, undertaken without ethics approval, formal interview protocol or transcription, is described by Gatley as 'multiple unplanned conversations and the spontaneous sharing of memory'. ${ }^{29}$ Gatley herself owns the house, and the article is entirely lacking in any attempt at reflexivity. The result is a

\footnotetext{
${ }^{24}$ Jessie Munro, The Story of Suzanne Aubert (Auckland: Auckland University Press and Bridget Williams Press, 1996).

${ }^{25}$ Chris Cochran, in discussion with author, 10 August 2017.

${ }^{26}$ Julia Gatley, "Life at the Rotherham House in the 1950s and 1960s," Fabrications: The Journal of the Society of Architectural Historians, Australia and New Zealand 24, no. 2 (3 July 2014): 244-267.

${ }^{27}$ Gatley, "Life at the Rotherham House," 246.

${ }^{28}$ Gatley, 245.

${ }^{29}$ Gatley, 245.
} 
descriptive rather than scholarly, somewhat repetitive account of the history of the house dominated by personal opinion, nostalgia and reminiscence.

- Wellington architectural and social historian Elizabeth Cox created a website for a well-known and historic Wellington church entitled: 'Old St Pauls, Wellington New Zealand: Bringing the Stories out of the Woodwork'. The beautifully presented website now contains over 100 assorted written stories which together explore the 'architecture and objects of the church, its congregation, clergy and community, and its myths and mysteries'. With the assistance of Victoria University of Wellington students, Cox has striven to create a 'biography of a church'. ${ }^{30}$

It is indicative of rapid developments in the oral history field, as it relates to built heritage, that these examples have all been produced since 2006. Taken together, they illustrate the increasing confidence, sophistication and relevance of oral material gathered through these projects and its influence on the final work produced. They show that oral history is now taken more seriously as a primary source of information for heritage professionals researching built heritage. For the case study in this thesis, we can learn from the confidence with which these projects have been undertaken and appreciate the skill with which the information gained has been woven into narratives.

\section{Heritage Professionals}

Heritage professionals working in Wellington include heritage consultants, academics, historians and conservation architects. Many belong to PHANZA — the Professional Historians' Association of New Zealand. To ascertain how New Zealand heritage professionals regard using oral history in their professional practice I contacted several Wellington-based heritage practitioners. The responses from, and conversations with, Elizabeth Cox, Ben Schrader, Chris Cochran, Michael Kelly and Jamie Jacobs provided insight into current thoughts and perspectives of using oral history as a part of the research process.

\footnotetext{
30 “Old St Paul's Wellington New Zealand,” Old St Paul's Wellington New Zealand, accessed 30 July 2018, https://osphistory.org.
} 
All the respondents agree that they have undertaken oral history, by its widest definition, as part of their research process. They describe chats with the neighbours over the fence, informal phone calls during which they scribbled notes on the back of an envelope and verbal information garnered from current or previous owners, builders or architects. Most describe material generated by this type of communication as providing helpful insight. Given this admission, it is surprising then that none of them routinely undertakes formal, planned, sitdown, recorded oral history. However, by placing these professionals on a spectrum, we can get a sense of the field in Wellington.

Of this group, social and architectural historian Cox is the most experienced and enthusiastic practitioner of formal oral history. Her response reflected on the experience of undertaking 25 interviews over the course of over a year for her history of Old St Pauls Church in Wellington. She described it as one of the projects that she had enjoyed most in her career to date. She said that she always takes up an opportunity to use oral history interviews when possible, as they provide details that can't be learned in any other way. She also described oral history as a way to fill a 'gap' of information relating to recent times - commenting that it is 'often easier to find documentary evidence for 100 years ago than 20 years ago'. She also described with appreciation 'the nicest, nicest people' she met during the course of these interviews. $^{31}$

At the other end of this Wellington spectrum, conservation architect Cochran draws the line at relying on oral sources. He treats oral interviews with both caution and scepticism. He avoids using oral history, but if it were the only source possible, he would use it only if he was able to verify and confirm information obtained with written sources. He is a strong believer in a traditional focus on archival material and getting the facts 'right' ${ }^{32} \mathrm{He}$ sees oral history as an arguably inferior and unreliable source primarily for social history, out of place in the process of writing serious conservation plans for heritage structures.

\footnotetext{
${ }^{31}$ Elizabeth Cox, email to author, 14 August 2017.

${ }^{32}$ Chris Cochran, discussion, 10 August 2017.
} 
The remaining practitioners sit between these two extremes, using oral history as a tool that is sometimes appropriate if used with caution. Heritage consultant Kelly acknowledged that through oral history 'some useful stuff has sometimes emerged'. ${ }^{33}$ Urban historian Schrader has also benefited from it, seeking to tell the stories of built heritage through oral history which examines social and physical fabric. ${ }^{34}$ Collectively, apart from Cochran, these heritage professionals agree that there are benefits from using oral history, sometimes obtaining information that would be impossible to glean from any other source. Cox acknowledges that it can give you 'details about a building that you cannot learn in any other way' and that it can 'add depth to a document'. ${ }^{35}$ Kelly uses oral history as a tool 'to fill gaps in more recent history'. ${ }^{36}$ Heritage manager Jacobs sees it as a way to get 'another dimension' and 'to understand the motivations of people creating buildings' ${ }^{37}$ All agree that oral history is particularly useful for establishing recent history.

However, there are obvious disadvantages to undertaking planned, sit-down, 'proper interviews'. Kelly notes 'the unreliability of people's memories, the bias of one individual's perspective and the difficulty (sometimes) of checking oral history against written archives' ${ }^{38}$ It is also noted that interviews are considered time-consuming and therefore costly to clients working within a modest project budget. ${ }^{39}$ Some heritage professionals, like Cox, would like to undertake more oral history, but it simply isn't practical when working to tight timeframes and limited budgets. Jacobs notes that oral history is 'one part of the tool kit not so much a central tool'. ${ }^{40}$

The combined advice of these heritage practitioners for heritage studies students striking out in their fields is pragmatic. Cox identifies preparation as key-she strongly recommends that the interviewer research the building thoroughly before the interview. She cautions the beginner not to expect people's recollections to match information from documents or those of other people also interviewed. She also notes the importance of maintaining privacy

\footnotetext{
${ }^{33}$ Michael Kelly, email, 29 October 2017.

${ }^{34}$ Ben Schrader, in discussion with author, 10 September 2017.

${ }^{35}$ Elizabeth Cox, email, 14 August 2017.

${ }^{36}$ Michael Kelly, email, 29 October 2017.

${ }^{37}$ Jamie Jacobs, email to author, 25 October 2017.

${ }^{38}$ Michael Kelly, email, 29 October 2017.

${ }^{39}$ Elizabeth Cox, email, 14 August 2017.

${ }^{40}$ Jamie Jacobs, email, 25 October 2017.
} 
between interviewees. ${ }^{41}$ Kelly advises newcomers to 'tread warily but never shy away from oral sources' but that they 'can make or break a history if you have limited material from other sources'. ${ }^{42}$ Jacobs suggests that every attempt to record interviews should be made, rather than relying on notes alone. ${ }^{43}$

\section{Background for the case study}

I chose to research Ngaroma as a case study because it has a fascinating history which, despite a wealth of archival material, has never been researched and written about in any comprehensive way. The building also lends itself to an oral history project because there are a number of people who have stories from their memories of the building and their connection to it, and through snowball sampling they were relatively easy to identify and contact. It is also timely that this project is undertaken now, as some of the interviewees are very elderly. The research process was rich and interesting. The first part of the process entailed researching at libraries and archives. I then undertook nine interviews with people who claimed some connection to the building.

Ngaroma is not currently registered on the New Zealand Heritage List Rārangi Kōrero at Heritage New Zealand, but its heritage significance has never been in doubt. It was first formally noted in July 1980 by what was then the Wellington Regional Committee of the New Zealand Historic Places Trust. It was considered for entry onto the register in March 1990, and the Trust proposed to allocate the building a ' $\mathrm{B}$ ' classification, a band which covers 'buildings which merit permanent preservation because of their very great historical significance or architectural quality'. The Trust approached the owners, the Holy See, but the papal nuncio objected to the proposed classification, arguing that Ngaroma was foreign territory and, therefore, under the Diplomatic Privileges and Immunities Act 1986 it had immunity from such classification. There followed a legal debate, in which the Trust argued that that no such legal impediment existed. But in October 1990 the Trust decided to defer the classification anyway. Today, Ngaroma still exists in Heritage New Zealand's internal

\footnotetext{
${ }^{41}$ Elizabeth Cox, email, 14 August 2017.

${ }^{42}$ Michael Kelly, email, 29 October 2017.

${ }^{43}$ Jamie Jacobs, email, 25 October 2017.
} 
database and their heritage advisor Blyss Wagstaff suggests that it is likely that the property will be listed at some point in the future. ${ }^{44}$

\section{Case Study Oral History Interviewees}

Nine people participated in oral history interviews in 2017 to contribute to this project. They were identified through snowball sampling. They are as follows:

John Gibbons - A New Zealander and descendant of the Hope Gibbons family. Since the 1980s he has worked as an accountant in the Hope Gibbons Building for the Hope Gibbons Family Trust. He is a godson of Paddy Hope Gibbons.

Stefania Zawada - Born in Poland in 1934. She came to New Zealand as a refugee aboard the USS General Randall in 1944. Her maiden name was Sondej. She lived at Ngaroma as a girl and while studying Russian at Victoria University of Wellington. She currently lives in Lower Hutt. She and her husband, Józef Zawada, were part of the committee which produced the book New Zealand's First Refugees: Pahiatua's Polish Children. ${ }^{45}$

Stefania Sondej - Born in Poland in 1934. She came to New Zealand as a refugee aboard the USS General Randall in 1944. Her maiden name was Manterys. She lived at Ngaroma during school holidays as a girl and later while studying at Victoria University of Wellington. She was a secondary school Latin teacher.

Maria Campbell - Born in Poland in 1939. She came to New Zealand in 1944 as a refugee aboard the USS General Randall with her mother, who was one of the caregivers. Her maiden name was Pytlos. She lived at Ngaroma as a very young girl.

Steve Fejos - Born in Wellington to Hungarian parents in 1959, while they were living at Ngaroma. A Wellington real estate agent.

Mary Papp - Born 1947 in Budapest, Hungary. Came to New Zealand as a refugee with her family aboard the Sibajak in 1959. Her maiden name was Takacs. Lived in Ngaroma as a girl.

\footnotetext{
${ }^{44}$ Blyss Wagstaff, Heritage New Zealand, email to author, 16 August 2017.

${ }^{45}$ Adam Manterys et al., New Zealand's First Refugees: Pahiatua's Polish Children (Wellington: Polish Children's Reunion Committee, 2016).
} 
Carmel Fahey - Born in Australia in 1929. Carmel immigrated to New Zealand. She and her late husband John were Kilbirnie residents and regular attendee of mass at the papal nunciature for many years.

Chris Hampton - Born in 1945 in Christchurch. He worked as the gardener at Ngaroma for the Vatican's papal nuncio for several years, retiring in 2015.

Jacqui Bisley - Born in 1961 in New Plymouth. She is a current neighbour of Ngaroma, resident at 102 Queens Drive. She was friends with the Workers of Christ the Worker Filipino nuns, Archbishop Charles Balvo and various monsignors at the papal nunciature.

\section{Conclusion}

Wellington's regulatory environment is influenced by various agencies, organisations and legislation, which together guide those undertaking heritage management. This chapter has outlined these then examined some of the work undertaken using oral history for built heritage research in a variety of formats both world-wide and within New Zealand. It has then discussed the results of communications with Wellington-based heritage professionals who briefly shared their ideas about and experiences with oral history. I have then looked at the background for the case study building and established the reasons for the choice of this building and briefly outlined the negotiations, regarding its listing, between various owners and Heritage New Zealand. The next chapter recounts the history of Ngaroma as a case study through the more traditional library- and archive-research approach before exploring in Chapter Three what oral history might bring to our understanding of the building. 


\section{Chapter Two - Case Study:}

\section{The Changing Fortunes of Ngaroma}

Only the best and most enduring of materials were used, and on account of its spaciousness, the richness of its appointments and the distinctive lay-out of the grounds it came to rank as one of the finest residences in the Metropolitan area. ${ }^{l}$

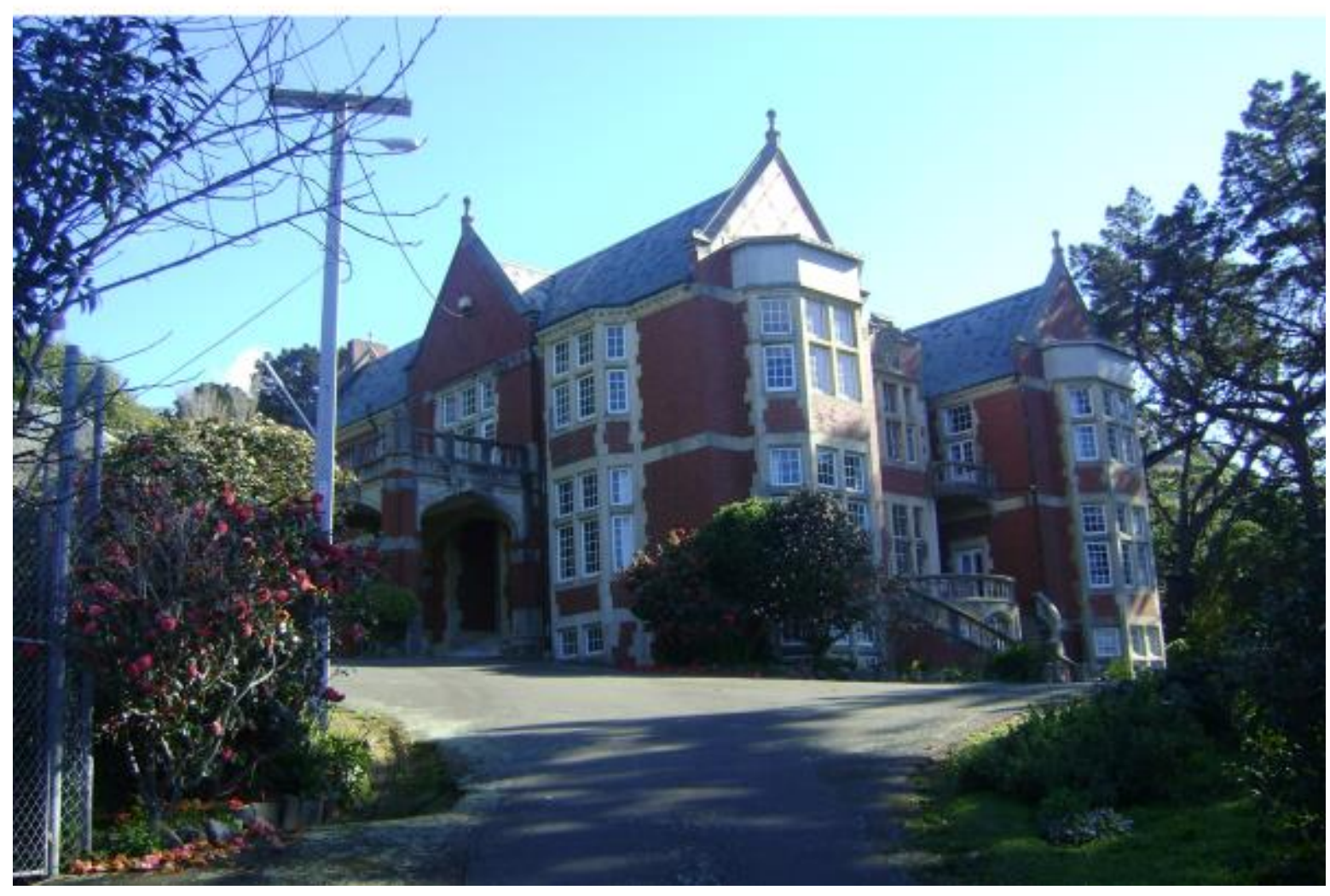

Fig. 2. Ngaroma, 2016. (Photo by author)

\footnotetext{
1 "The Ursuline Sisters Come to Kilbirnie," The Record: The Monthly Journal of St Patrick's Parish, Kilbirnie, February 1948, 1.
} 


\section{Introduction}

The previous chapter has established the setting and background for this thesis by situating it within the heritage management context of Wellington. It has identified the case study building, Ngaroma, and the nine people who have contributed oral histories. Ngaroma is a magnificent three-storey, Elizabethan-style brick building located at 112 Queens Drive in Wellington, situated in a sprawling established garden with commanding views of Lyall Bay. It has an unusual history which has received little attention from both amateur and professional historians. This chapter establishes its history by compiling material from books, manuscripts, magazine and newspaper articles, photos, maps and plans drawn from library and archival sources to create a base history from which we can, in the next chapter, add oral interviews to test the usefulness of oral history as a methodology for heritage professionals.

Ngaroma has had a variety of owners and uses. It was designed in 1926 by Wellington architect Joseph McClatchie Dawson for Hopeful Barnes Gibbons, his wife Daisie and their young family - its proportions and grandeur designed to reflect their prestige and wealth. The many parties, fêtes and balls held in the palatial central hall and garden and those who attended were followed avidly by the newspapers of the day. In 1947 the building was sold to the Catholic Church and opened its doors as an Ursuline convent and as the Polish Girls' Hostel, caring for primarily Polish children who had been evacuated from Europe and, until then, had been accommodated at the Polish Children's Camp at Pahiatua. The house next found new purpose as an emergency emigration hostel, administered by the Wellington branch of the Society of St Vincent de Paul, who provided accommodation for mainly Hungarian refugees integrating into New Zealand society. Later, the Sisters of the Good Shepherd briefly ran the house as a Catholic women's hostel between 1967 and 1969. The building then housed the apostolic delegate and was subsequently established as the Vatican's papal nunciature, before passing back into private ownership in 2015. 


\section{Hayward builds on Melrose Estate}

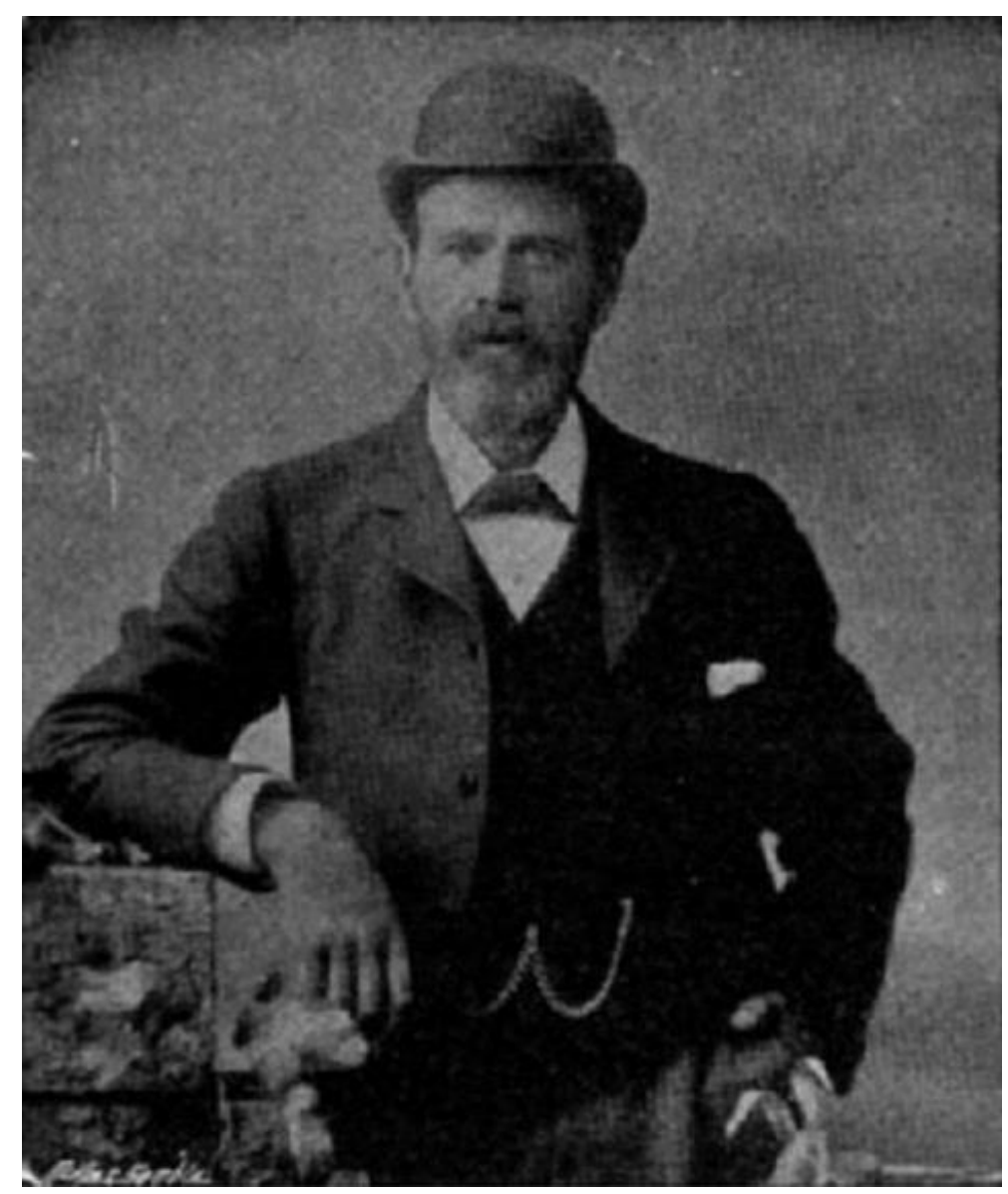

Fig. 3. Harry Miles Hayward. The Cyclopedia of New Zealand (Wellington: The Cyclopedia Company, 1897), 803.
The first person recorded as having built on the site now occupied by Ngaroma was Harry Miles Hayward. Hayward was born in Yeovil, in Somersetshire and had arrived in Wellington from England in 1877 aboard the ship Calypso, aged just $21 .^{2} \mathrm{He}$ was an agent for a number of important English manufacturing firms, and this position necessitated frequent travel. ${ }^{3}$ Hayward married Jessica Burne Luxford on 2 June 1886 at Wellington's Anglican St Peter's Church. ${ }^{4}$ Jessie was the daughter of one of Wellington's earliest settlers, George Henry Luxford and his second wife Mary, who had been part of the Melrose

Proprietors' syndicate bought out by Hayward when he purchased the property, Melrose Estate. In 1888 Hayward oversaw the construction of a two-storey timber house. ${ }^{5}$ There are no extant plans, and the circa 1896 Figure 4 image is the only photograph of the house surviving in the public record. It shows the isolation of the house at the time, set amid grazing land and overlooking the sand dunes (now gone) of Lyall Bay.

\footnotetext{
2 "Early Days of City Recalled by Mr Hayward," The Dominion, 27 October 1948, 11.

3 "Borough Of Melrose | NZETC," accessed 2 August, 2017, http://nzetc.victoria.ac.nz/tm/scholarly/teiCyc01Cycl-t1-body-d4-d64-d3.html\#name-414593-mention.

4 "Marriage.," New Zealand Times, 8 June 1886, 2.

${ }^{5}$ F. L. Irvine-Smith, The Streets of My City; Wellington, New Zealand. (Wellington and Auckland: Reed, 1967), 277.
} 
Hayward was a keen gardener. At the time, the property had little established vegetation, and during their golden wedding celebration in 1936, the Haywards reminisced about their struggle to establish a garden on the exposed hillside. They recalled that 'the southerlies were so severe that [Hayward] sometimes had to plant trees three or four times'. ${ }^{6}$ At this time, access to the property was through the area where the Newtown Zoo is now. ${ }^{7}$ In 1896 The Queen's Drive (later known as Queens Drive) was constructed on two and a half miles of land, much of which Hayward had gifted to the city for this purpose. ${ }^{8}$ At a time of economic depression, this was part of a larger scheme which provided work for an estimated one thousand men who were unlikely to have found any other employment. ${ }^{9}$ This new road improved access and encouraged a flurry of subdivision in the late 1890s, which resulted in a number of houses being constructed in the area now known as Melrose. ${ }^{10}$

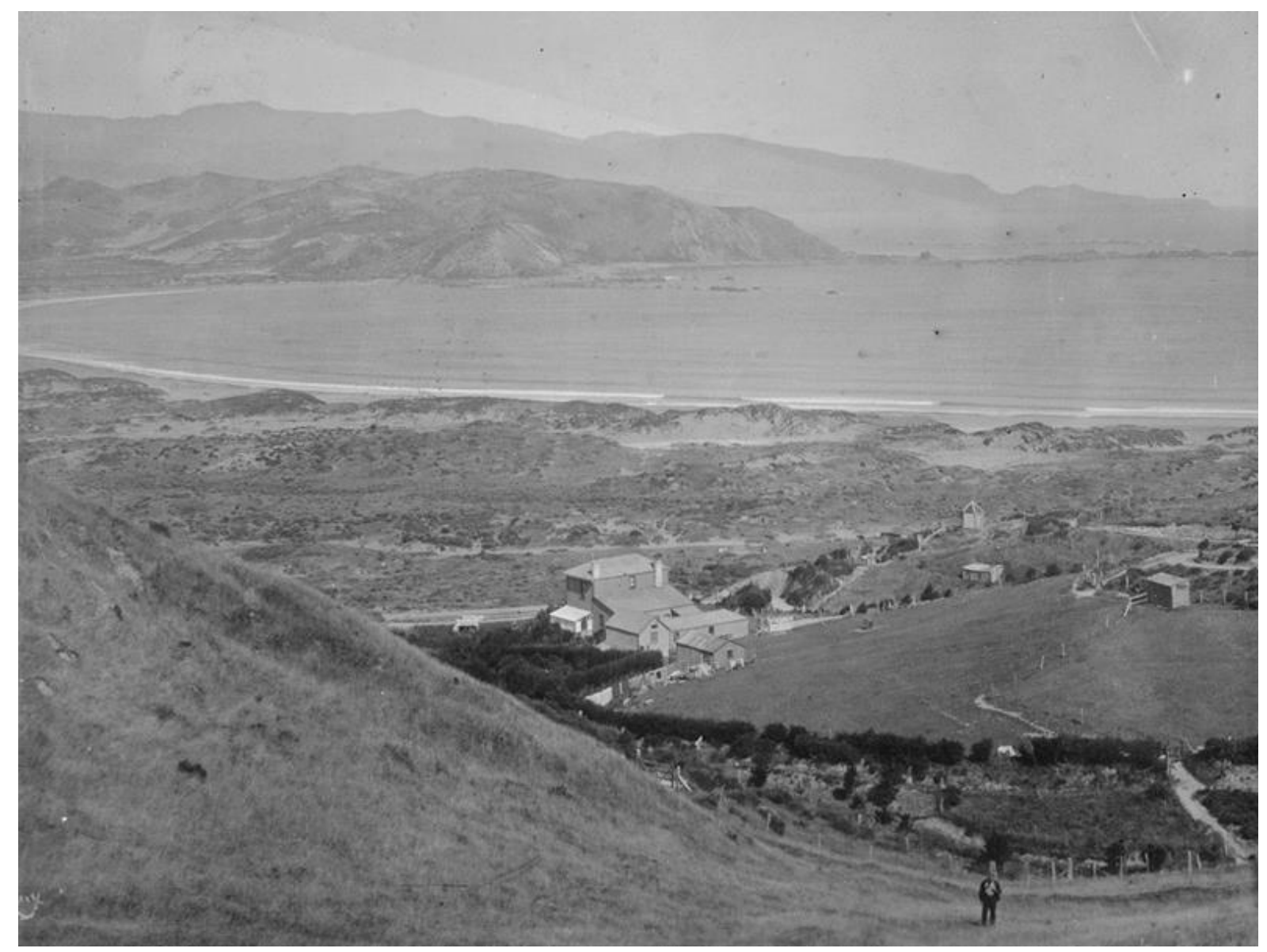

Fig. 4. Harry Miles Hayward's residence at Melrose Estate, overlooking Lyall Bay, c.1896, Wellington City Archives, [00138:0:11593]

\footnotetext{
6 "Golden Wedding," Hutt News, 10 June 1936, 3.

7 "Golden Wedding," 3.

${ }^{8}$ Irvine-Smith, The Streets of My City, 278.

${ }^{9}$ Irvine-Smith, 278.

${ }^{10}$ Adrian Humphris and Geoff Mew, Ring around the City: Wellington's New Suburbs, 1900-1930 (Wellington: Steele Roberts, 2009), 59.
} 
Harry and Jessie lived in the Melrose property for 18 years, raising a son and daughter there, Muriel and Cyril, before selling the house and moving to a new home at White's Line in the eastern hills of Lower Hutt in 1908. ${ }^{11}$ Their legacy to Ngaroma was in establishing both the driveway and the widely admired garden, planting trees and shrubs which were later to provide a backdrop to the many celebrations held in the house's grounds. The early layout of the garden can be seen in Figure 5.

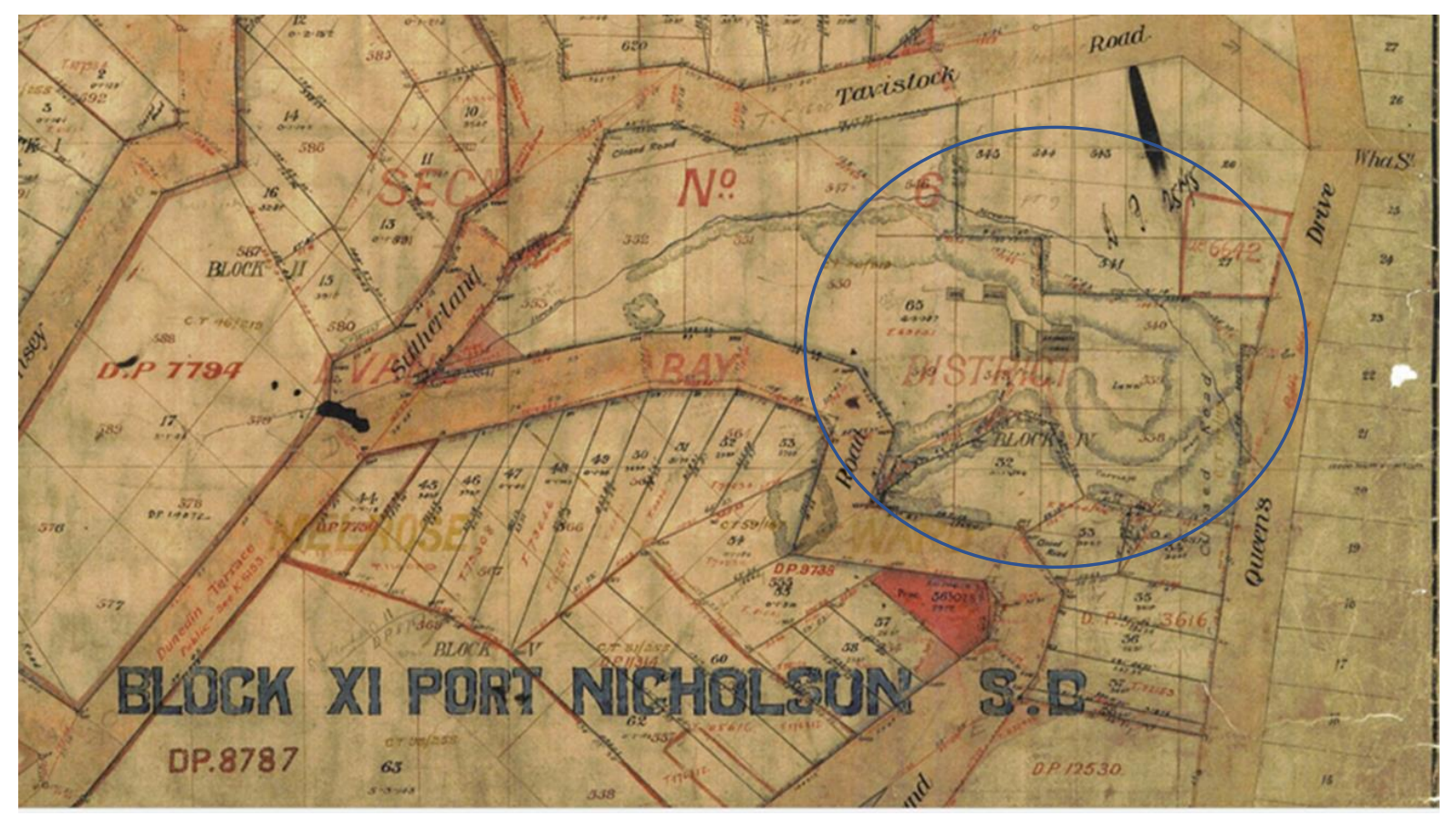

Fig. 5. Plan showing the site of Harry Miles Hayward's house, Melrose Estate, and garden and approach. Plan of 1889, Subdivision of Part of Section 6, Evans Bay District, Surveyed for Harry Miles Hayward, by HP Hanify Licensed Surveyor, undated, Deposited Plan 1889. (Reproduced by permission from LINZ - contains data sourced from the LINZ Data Service licensed for reuse under CC BY 4.0 license)

\section{George Winder buys Melrose Estate (1908-1914)}

Irish-born George Winder purchased the Melrose Estate and property from Hayward in 1908. ${ }^{12} \mathrm{He}$ was an importer of furnishings and ironmongery and a well-known Wellington City councillor. At his shop on the corner of Cuba and Manners streets in the city he sold 'galvanised iron, fencing wire, spouting, ridging, white lead, oils and paints, ranges, grates, wringers, bedsteads', and by 1907 his stock had extended to include carpets, linoleums, lace

\footnotetext{
11 “Golden Wedding," Evening Post, 3 June 1936, 15.

${ }^{12}$ CT WN46/219
} 
curtains and table linen. ${ }^{13}$ Pat Lawlor recalls his childhood fascination with Winder's shop in Wellington's city centre:

I can never forget Winder's wonderful shop. It was situated at James Smith's corner, and was of vast extent. You could buy anything from a tack to a tram rail. Everything was displayed in colossal bins. He had enough picks and shovels to excavate a Suez Canal. The place rang with the clash of metal as bolts and bars were planked on the ponderous weighing machines...Presiding over this vast aggregation of metal was the sad, large-eyed, little man named George Winder. Even an occasional visit to Mrs Whelan's at The Alhambra over the way would not dispel his cast-iron gravity. $\mathrm{He}$ spent much of his time standing in the main entrance with a mournful eye for passersby and for the huge clothes baskets of hinges, handles and castors on outside display. The shop had six windows and was one of the largest in the city. ${ }^{14}$

After living at Melrose Estate for six years, Winder sold it in 1914.

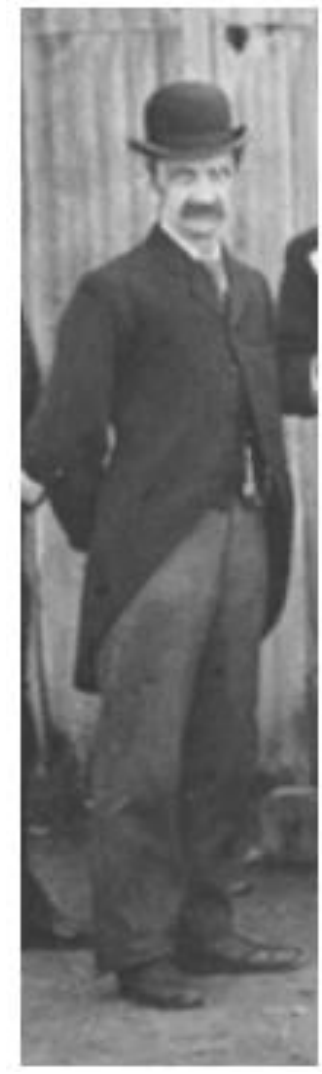

Fig.6. George Winder, detail from a group photograph outside the Adelaide Road tram barns, on the occasion of the municipalisation of the tramway, 1900, Wellington City Archives, [00138:0:8703]

13 “Mt Victoria Historical Society George Winder," accessed 2 August 2017, http://mtvictoria.history.org.nz/george-winder/.

${ }^{14}$ Pat Lawlor, Old Wellington Days (Wellington: Whitcombs \& Tombs Limited, 1959), 88-89. 


\section{Hopeful Barnes and Daisie Hope Gibbons (1914-1947)}

In 1914 Hopeful Barnes Gibbons purchased the property. He envisaged a grander home than the one existing on the site, and the blueprints for a more palatial residence were drawn up early in 1926 by architect Joseph Dawson, who became something of a house architect for the Gibbons family. The family lived at the property from 1918 and it is likely that they lived at Hayward's house while the new residence was planned and constructed. ${ }^{15}$ The new building was named 'Ngaroma' - a Māori word meaning 'stream' or 'current', probably because of the creek running through the rear of the property. The house was destined to become one of

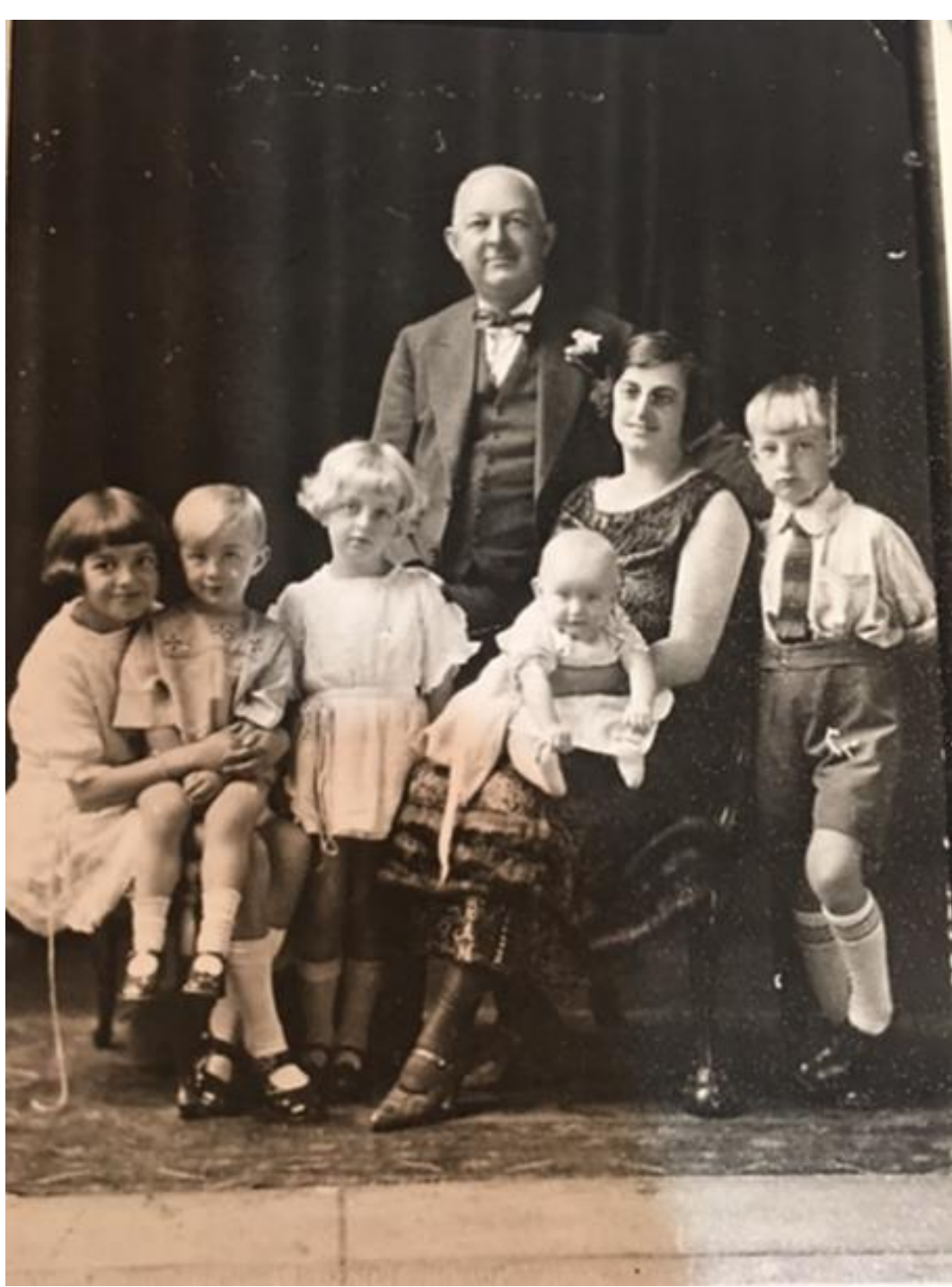

Fig. 7. Hopeful Barnes and Daisie Gibbons with their children. Reproduced by permission from Stuart Gibbons. the greatest and most

opulent of Wellington's

residences.

Hopeful Barnes Gibbons'

success as a businessman had its roots in his family's business. He was one of five children and the eldest son of (the similarly named) Hopeful Gibbons and his wife Jessie of Whanganui. His father had worked hard to set up the Pātea Brewery in 1879 , and the business had prospered. The family worked together, driven by their core values of 'diligence, hard work, thrift and family solidarity' with an emphasis on family unity in business ventures. ${ }^{16}$ The

\footnotetext{
${ }^{15}$ Wises New Zealand Post Office Directory (New Zealand: H. Wise and Co Ltd, 1918), 1014.

16 Yvonne Dasler, “The Hope Gibbons," Wellington City Magazine, August 1985, 65.
} 
family branched out into various other ventures. They ran a flax-milling business in the Manawatū, an engineering company in Palmerston North and the Southern Cross biscuit company and acquired farmland. Hopeful Gibbons later proudly claimed that 'every family enterprise was a business success'. ${ }^{17}$ Hopeful Gibbons' son, Hopeful Barnes Gibbons, joined J. B. Clarkson and Co, a cycle-importing firm based in Palmerston North, as its director in 1905, when his family acquired 50 per cent of the company's shares. In 1910, he moved with the business to Wellington and in 1918 the family purchased a controlling interest in the Ford dealership, the Colonial Motor Company Ltd. Two years later the company constructed the first purpose-built car assembly plant in New Zealand adjacent to the company's Wellington Courtenay Place office building. The company's name changed to Hope Gibbons Ltd and Hopeful Barnes Gibbons became its managing director. ${ }^{18}$ He was also associated with the New Zealand Wholesale Motor and Cycle Trade Federation Limited. ${ }^{19}$

Hopeful Barnes and Daisie Gibbons had purchased the 2.47-hectare Queens Drive property as a site for their new family home. ${ }^{20}$ Gibbons sought an architect to design a grander residence that would reflect the prosperity and prestige of his family name. The architect he chose was Joseph McClatchie Dawson, who had already designed the recently completed Hope Gibbons Building in Wellington's Courtenay Place. Dawson's design for Ngaroma was a departure from the scale and style of other, more modest, buildings he had worked on. Born in Christchurch in 1876, he studied architecture at Wellington Technical College between 1898 and $1899 .{ }^{21}$ After travel in South Africa,

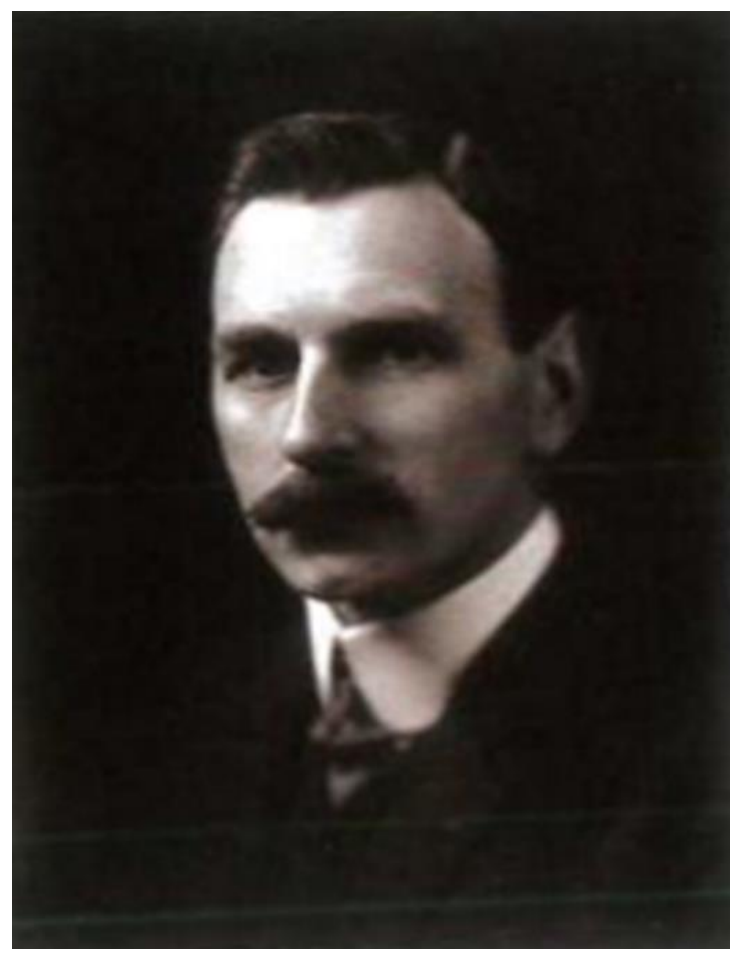

Fig. 8. Architect Joseph McClatchie Dawson. Reproduced by permission from Hilary Eats.

\footnotetext{
${ }^{17}$ Dasler, "The Hope Gibbons," 66.

${ }^{18}$ Diana Beaglehole, “Gibbons, Hopeful," Te Ara: The Encyclopedia of New Zealand, accessed 3 August 2017, http://teara.govt.nz/en/biographies/3g5/gibbons-hopeful.

19 "Death of Prominent Personality In The Motor Industry," The Dominion, 10 December 1955, 15.

20 “The Nunciature Closes," St Patricks Church News \& Views, April 2015, 4.

${ }^{21}$ Mew and Humphris, Raupo to Deco, 171.
} 
England and Australia he returned to establish his own practice in Wellington in $1906 .^{22}$ Dawson designed buildings as far afield as Palmerston North, Blenheim and Auckland, but between 1907 and 1928 Dawson was instrumental in the design of at least 60 buildings in Wellington, mainly commercial in purpose, but also several houses, a church and a block of flats. ${ }^{23}$ Of note in Wellington are the T. G. McCarthy Building (1913), Hatricks Motor Garage (later Manthel Motors, now Xero 1913) and the Hope Gibbons Building in Dixon Street mentioned earlier (1925). Dawson went on to establish an architectural partnership with Jack King, known as Dawson \& King, in 1929, which continues to this day. He was a member of the New Zealand Institute of Architects and president of its Wellington branch in 1939 and 1940, and was also on the board of the Wellington Technical College. ${ }^{24}$

Dawson completed the original plans for Hopeful Barnes Gibbons in January $1926 .{ }^{25} \mathrm{He}$ drew up more than 20 pages of plans, and Jack King worked on some of the detailing. The blueprints included not only the house, but also a garage and water tower designed in similar style and situated in the grounds. The construction of the house was initially estimated at a cost of around $£ 20,000 .{ }^{26}$ The final figure was at more than $£ 30,000 .{ }^{27}$ The press of the day avidly followed the construction in which 'only the best and most enduring of materials were used' ${ }^{28}$ The house was largely completed by 1928 and comprised 40 rooms and a total of 1,160 square metres. $^{29}$

Dawson had designed the building in the Elizabethan architectural style. Cochran describes the building thus:

[Ngaroma is] characterised particularly by the strapwork (the patterned stone and brick surfaces, most evident in the high gables); the fenestration, which comprises small-paned sashes divided by stone [actually concrete] mullions and transoms, and castellations which form the top of the parapet walls. The house is three storeys high,

\footnotetext{
${ }^{22}$ Mew and Humphris, 171.

${ }^{23}$ Mew and Humphris, 171.

${ }^{24}$ Mew and Humphris, 171.

${ }^{25}$ Wellington City Archives, [00056:9:B887]

${ }^{26}$ Wellington City Archives, [00056:9:B887]

${ }^{27}$ Neil Kemp, “King \& Dawson: An Historical Study, 1906-1981” (1982), 75.

28 "The Ursuline Sisters Come to Kilbirnie," 1.

29 "The Nunciature Closes," 4.
} 
in brick construction, although it is presumed that there is reinforced concrete forming a significant structural component. It is most imposing on its east (garden) elevation where a generous flight of curved stairs with stone balustrade flows down from the first floor loggia. The south elevation, two storeys high, has the main entrance sheltered by a porte-cochère. This opens into a generous hall with formal rooms (and the loggia) opening off it. On the first floor, the original plans show 10 bedrooms, the larger ones well supplied with wardrobes and dressing facilities, and three bathrooms; four small ones in the rear wing are presumably servant's rooms. ${ }^{30}$

The scale of the house and its architectural style are unusual in Wellington and the building continues to be one of the most magnificent residential homes in the city.

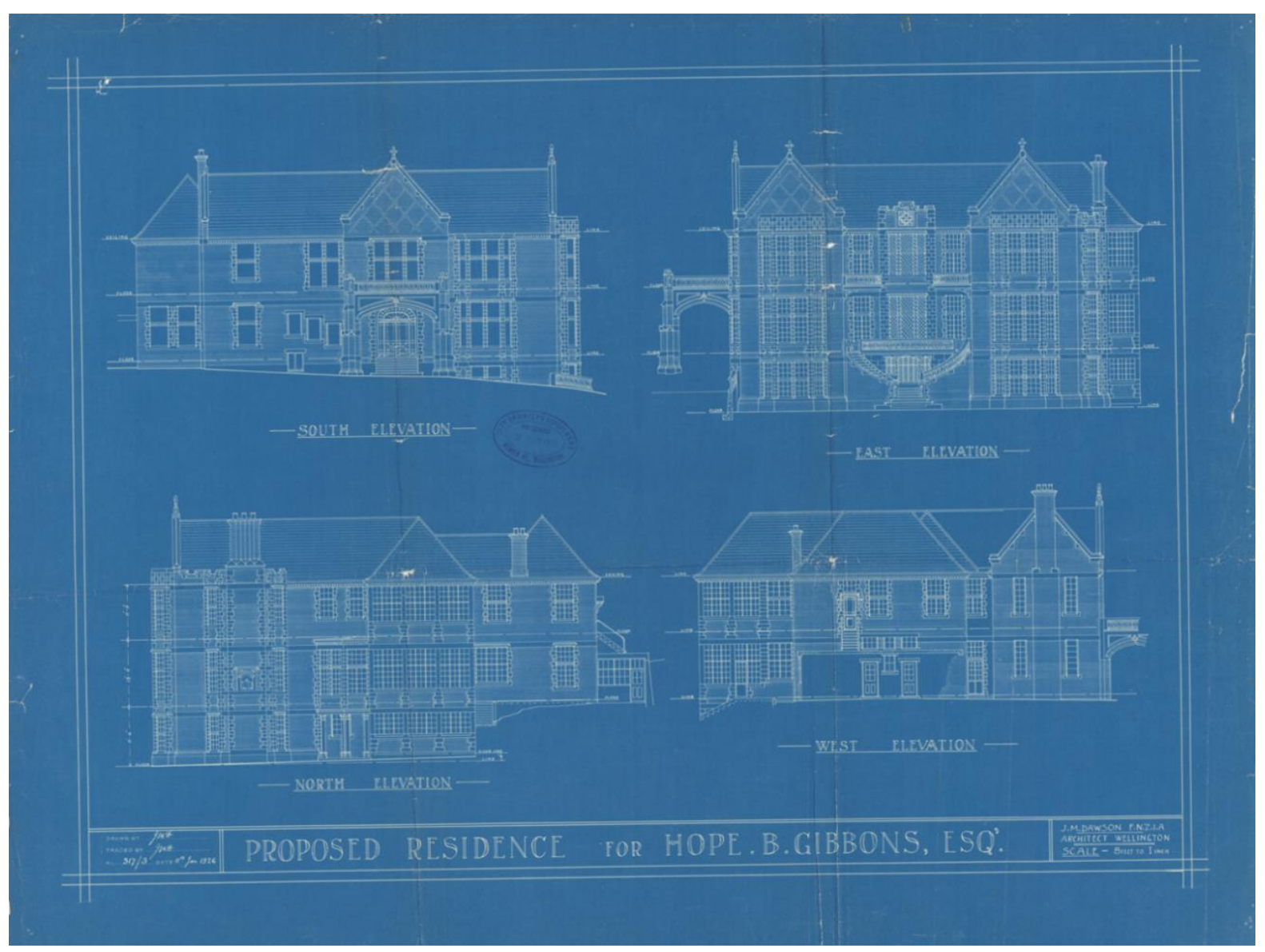

Fig. 9. Dawson's elevations of Ngaroma, 1926, Wellington City Archives, [00056:9:B887]

30 "NZ Historic Places Trust Inventory," n.d. 


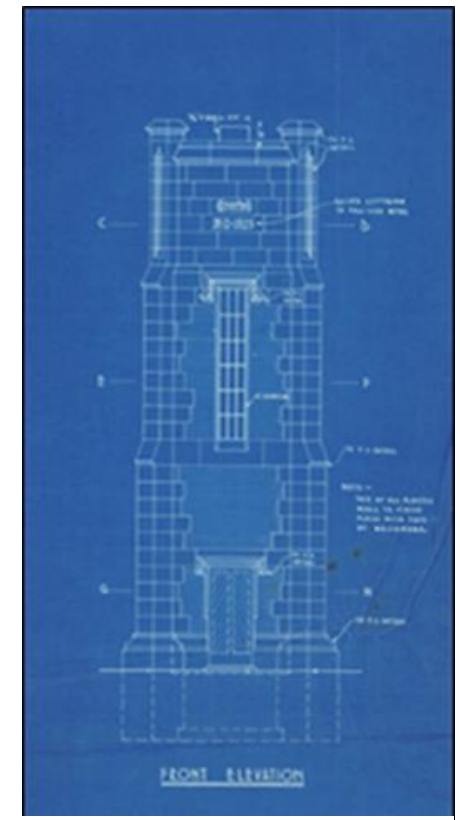

Fig. 10. Detail of Dawson's plan for the water tower, Wellington City Archives, [00056:9:B887]

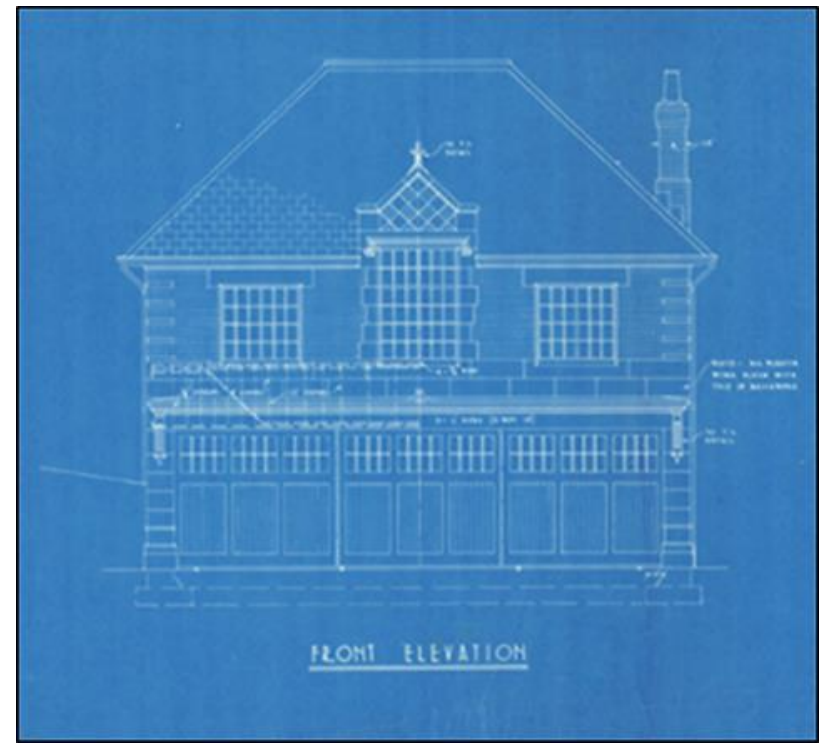

Fig. 11. Detail of Dawson's plan for the separate garage building, Wellington City Archives, [00056:9:B887]

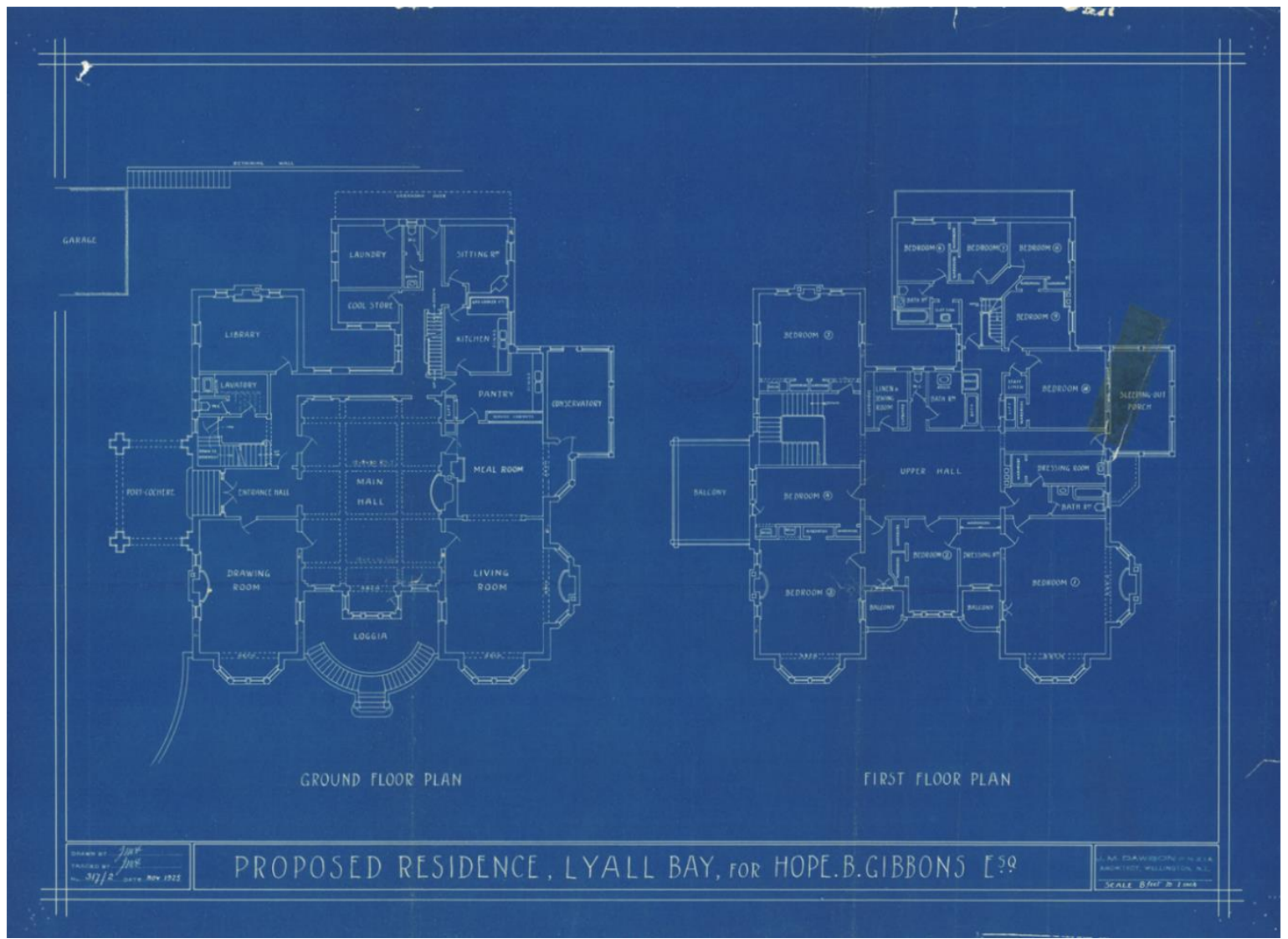

Fig. 12. Dawson's plans of ground floor and first floor of Ngaroma, Wellington City Archives, [00056:9:B887] 


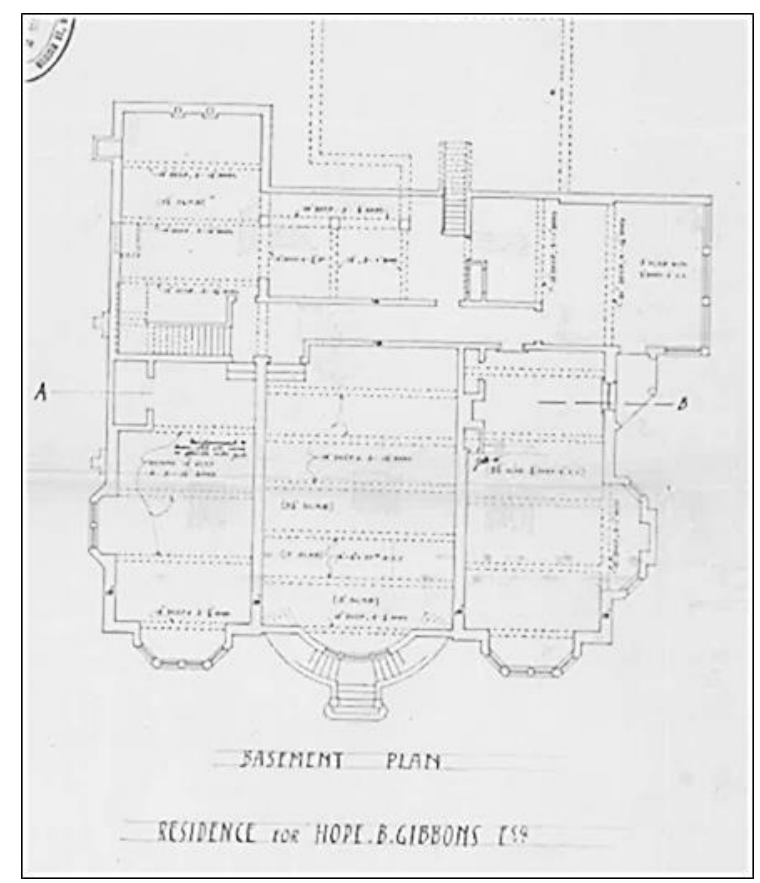

Fig. 13. Dawson's

basement plan for

Ngaroma, Wellington City

Archives, [00056:9:B887]

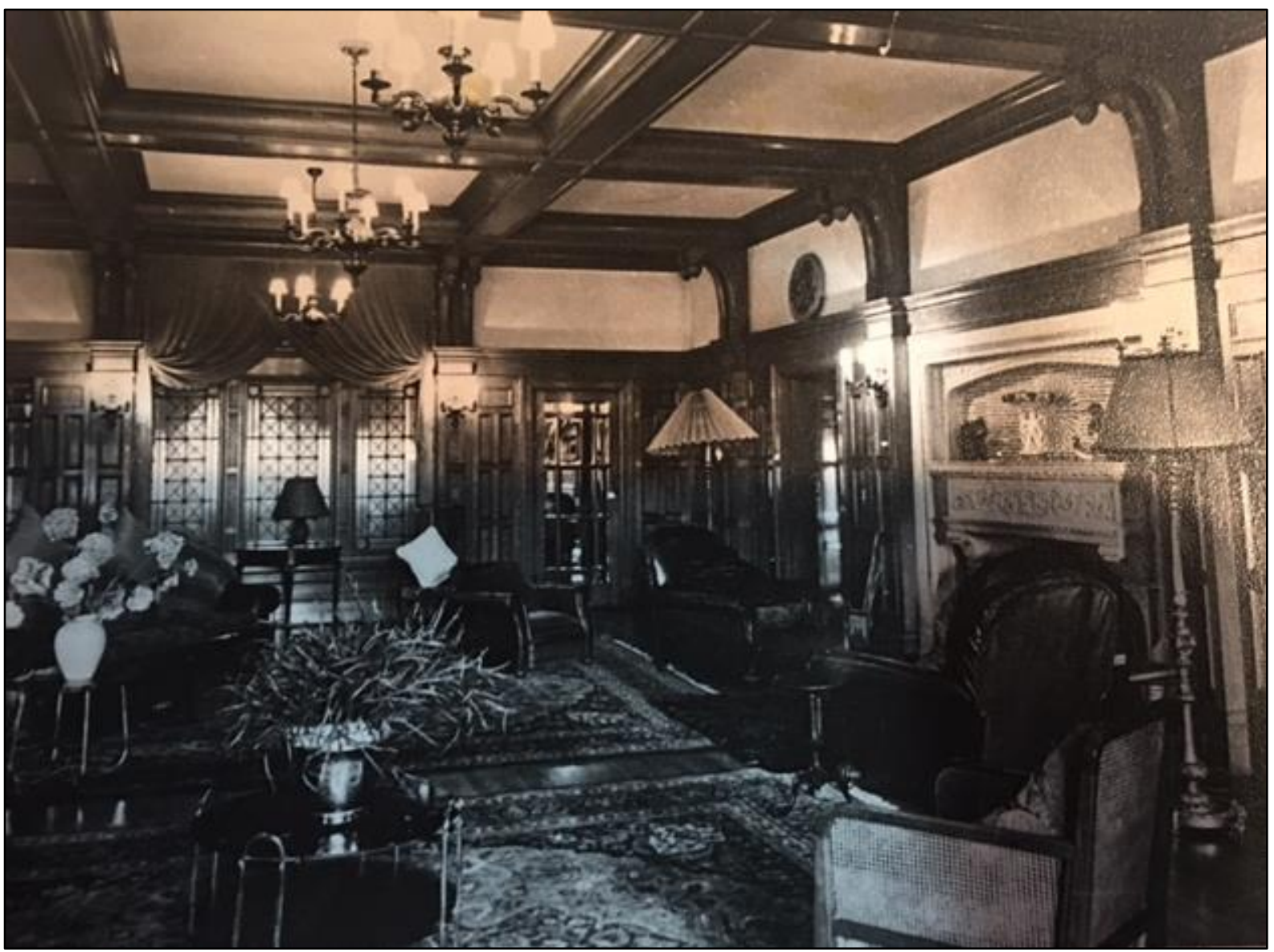

Fig. 14. The central hall at Ngaroma while Hopeful Barnes and Daisie Gibbons were in residence. Reproduced by permission from Stuart Gibbons. 


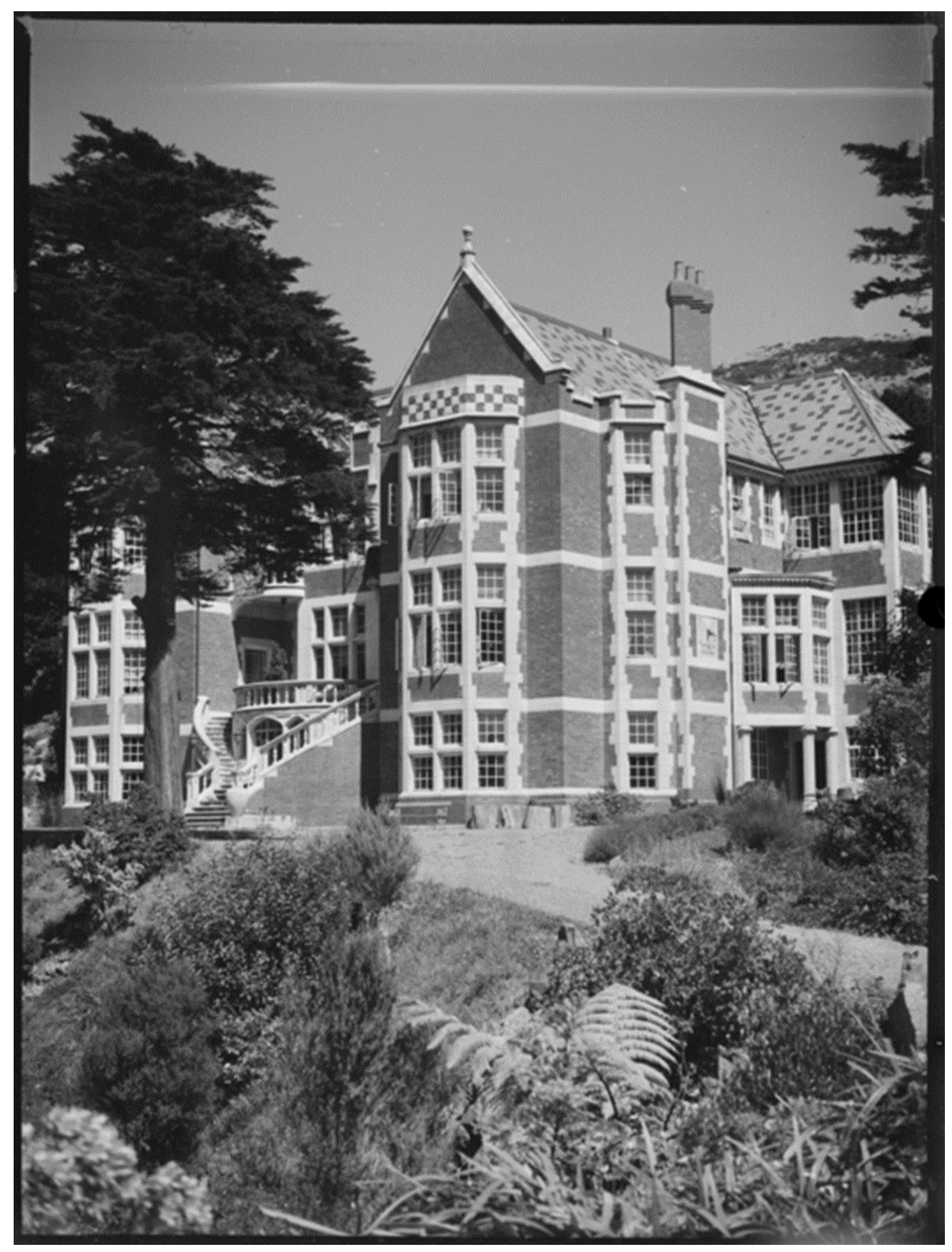

Fig. 15. Ngaroma at Lyall Bay, Wellington, c.1930, Ref: 1/4-028597-G, Alexander Turnbull Library, Wellington, New Zealand 
Hopeful Barnes, his wife Daisie, and their young children Amy (Paddy), Hopeful (Bunny), Jessie (Bobby), Gordon and Barnes Hope Gibbons moved into the spacious new home around 1928. Local newspaper The Record noted that 'on account of its spaciousness, the richness of its appointments and the distinctive lay-out of the grounds it came to be known as one of the finest residences in the Metropolitan area'. ${ }^{31}$ An Auckland paper described the interior: 'all decorated in Tiffany-style - rough cast, creamy and gold-tinted walls, and very picturesque panelled effects in rainbow hues'. ${ }^{32}$ The beauty of the house extended to the grounds.

Hopeful Barnes Gibbons was also a keen gardener and took over the cultivation of the bush and gardens that Hayward had first struggled to establish in the late 1800s. He had a plant propagation house and glasshouse built at the rear of the house and served as President of the NZ Alpine and Rock Garden Society. ${ }^{33}$

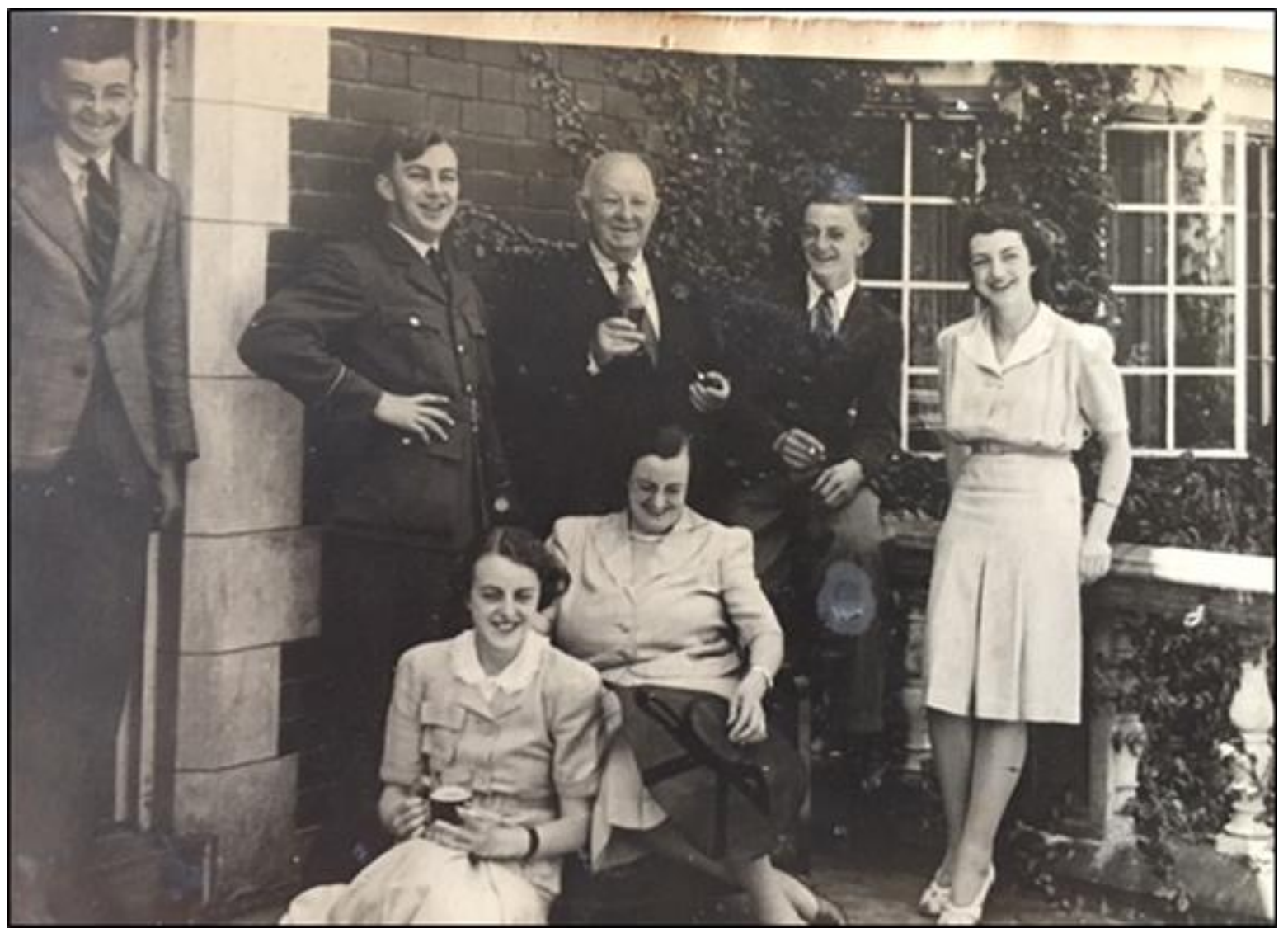

Fig. 16. All the family except for Bunny, pose outside Ngaroma. Reproduced by permission from Stuart Gibbons.

\footnotetext{
31 "The Ursuline Sisters Come to Kilbirnie," 1.

32 "The Social Sphere," The New Zealand Observer, 23 July 1931, 12.

${ }^{33}$ Wellington City Archives, [00056:208:B18008]
} 


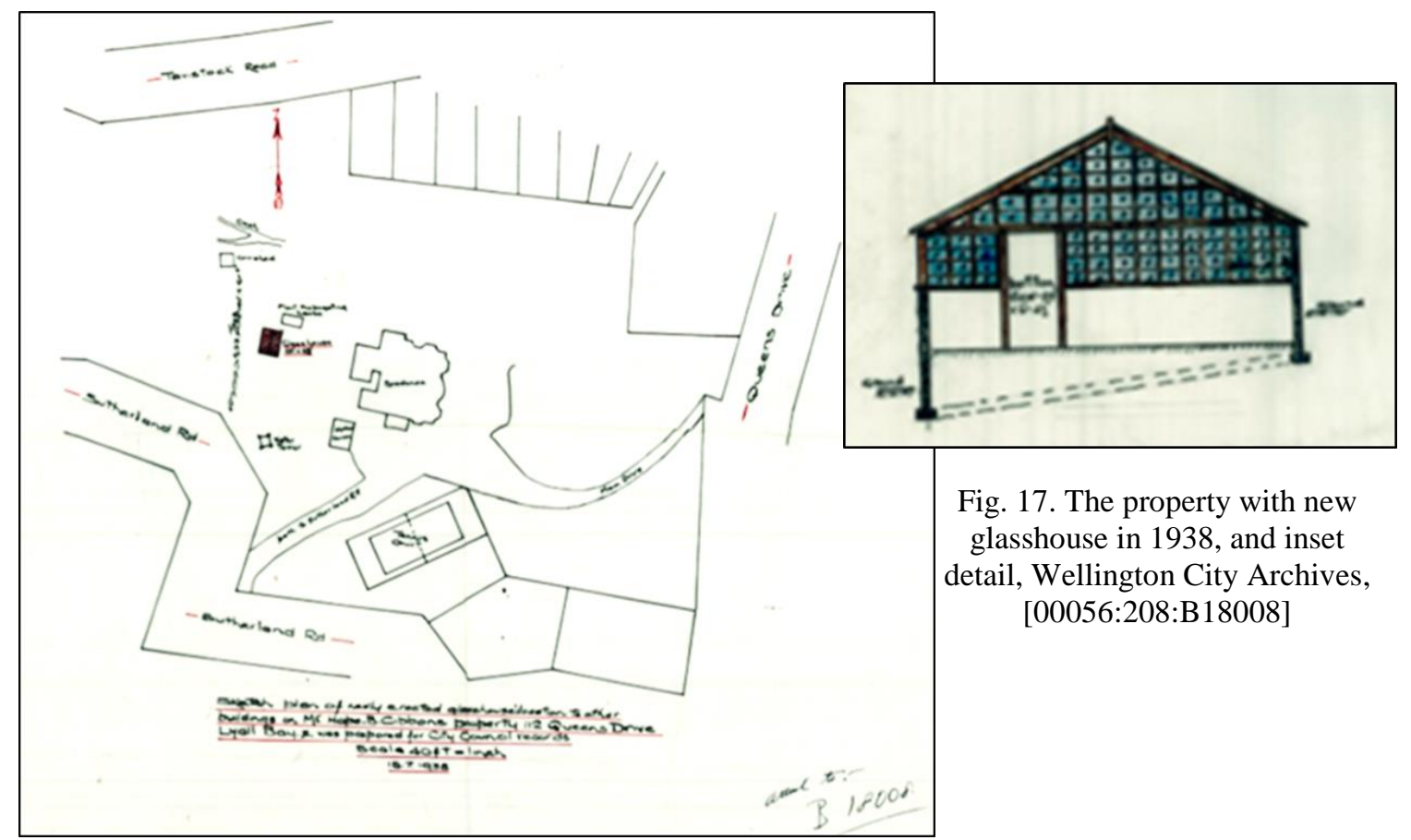

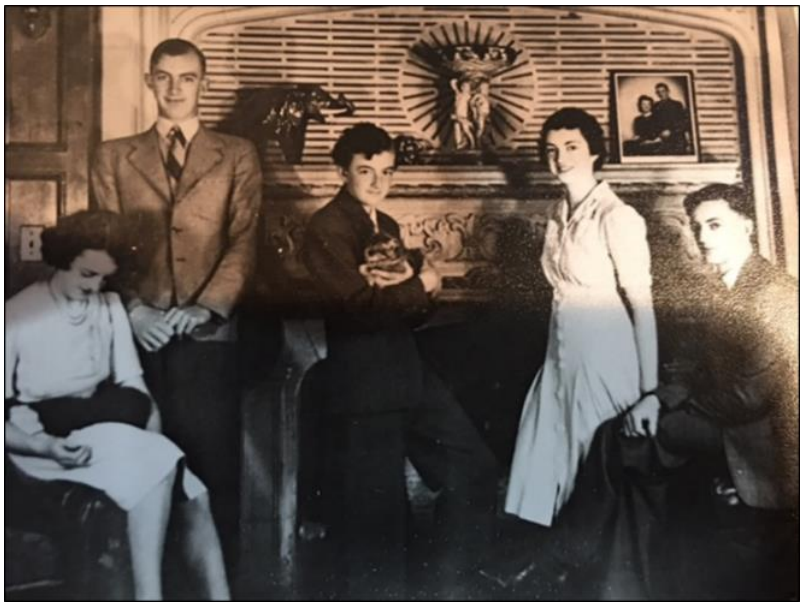

Fig. 18. The children.

Reproduced by permission from Stuart Gibbons.
The family enjoyed a Gatsbyesque existence and the frequent and extravagant parties Hopeful Barnes Gibbons and his wife Daisie hosted were detailed in the press of the day. The fêtes, balls and parties frequently made the local press, journalists noting the decorations, describing the gowns and a Who's Who of attendees. The events included fundraisers for worthy

causes including the Plunket Society, the National Council of Women, Rotary and kindergartens, and they also hosted annual balls for the boys from nearby Scots College. ${ }^{34}$

Fig. 19. Plunket Society fundraiser in the grounds of Ngaroma (Evening Post, March 6, 1933), 5.

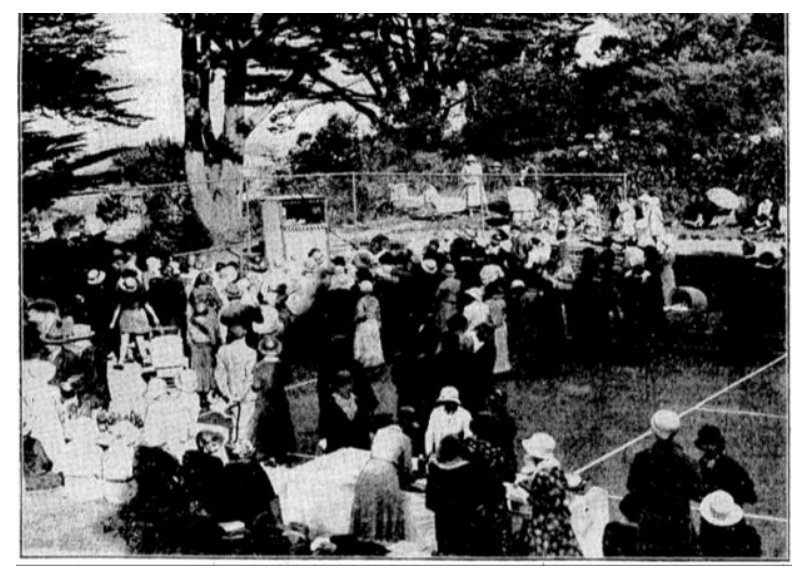

\footnotetext{
34 Terence E. R. Hodgson, The Big House: Grand \& Opulent Houses in Colonial New Zealand (Auckland: Random Century, 1991), 96.
} 


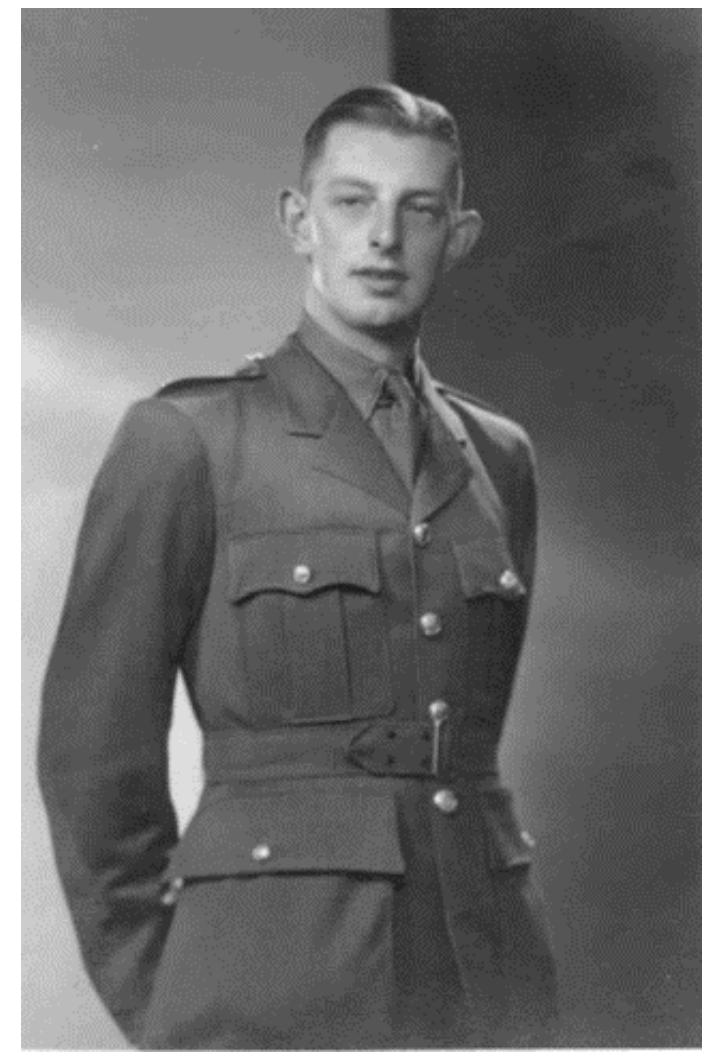

Fig. 20. Hopeful Hope Gibbons. Online Cenotaph. Reproduced by permission from Auckland War Memorial Museum Tāmaki Paenga Hira. Kindly donated by family.
This lifestyle ended with the outbreak of the

Second World War and the necessity of a more subdued and frugal existence. Their son, Hopeful Hope Gibbons (known to the family as 'Bunny', perhaps due to his prominent ears), served in the New Zealand Army Service Corps. He was killed in battle on 2 June 1941 - heroically trying to prevent allied maps falling into enemy hands at Ruin Hill in the Crete campaign. Aged just 23, he left behind his family, including a widow, Thelma. ${ }^{35}$

Happier times followed when Ngaroma hosted the celebration of daughter Paddy Gibbons' marriage to Squadron Leader Ellett Forbes Page on 10 September 1945, just days after the end of the Second World War. ${ }^{36}$ The marriage was not destined to last.

But the days of grand society occasions at Ngaroma were over and two years later, in 1947, Hopeful Barnes Gibbons sold the property and he and Daisie retired to a more modest residence across the harbour in Eastbourne. This concludes the story of the first and most opulent chapter of Ngaroma's history.

Fig. 21. Paddy marries Squadron Leader Ellett Forbes Page at St Jude's Church in Lyall Bay, (Evening Post (microfilm), 10 September 1945), 8.

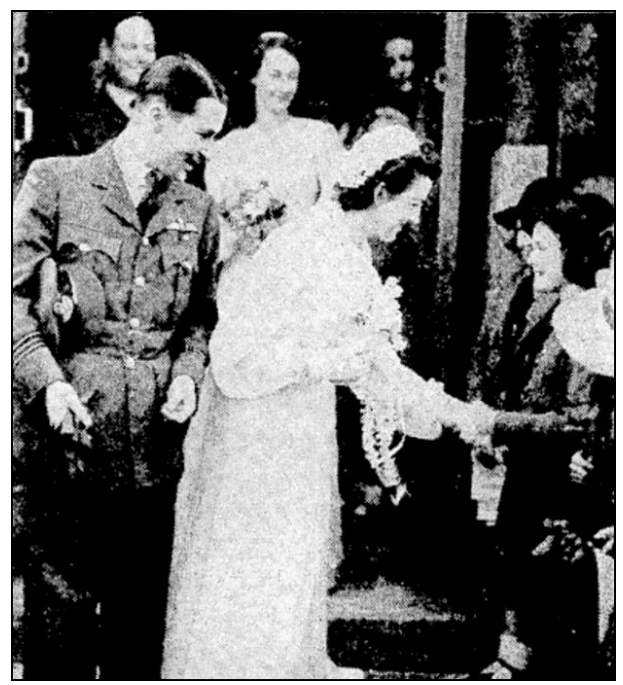

\footnotetext{
${ }^{35}$ Auckland War Memorial Museum, "Hopeful Hope Gibbons,” Auckland War Memorial Museum, accessed 3 August 2017, http://www.aucklandmuseum.com/war-memorial/online-cenotaph/record/C24295.

36 "Saturday's Bride, Miss Paddy Hope Gibbons, Elder Daughter of Mr and Mrs Hope B. Gibbons, "Ngaroma," Evening Post, 10 September 1945, 8.
} 


\section{Ursuline Sisters' Convent and Girls' Hostel (1947-1958)}

The next occupants at Ngaroma came from very different circumstances. Their story begins in the chaos of Second World War Europe. In 1939 Germany invaded Poland and the USSR occupied the eastern side of the country. Some 1.7 million Poles were systematically 'ethnically cleansed' by the Russian Secret Police; they were rounded up and deported in cattle trucks to various forced-labour camps scattered across the Soviet Union. Of these, over a million died and the fate of around 200,000 remain unaccounted for. ${ }^{37}$ In this turmoil, many

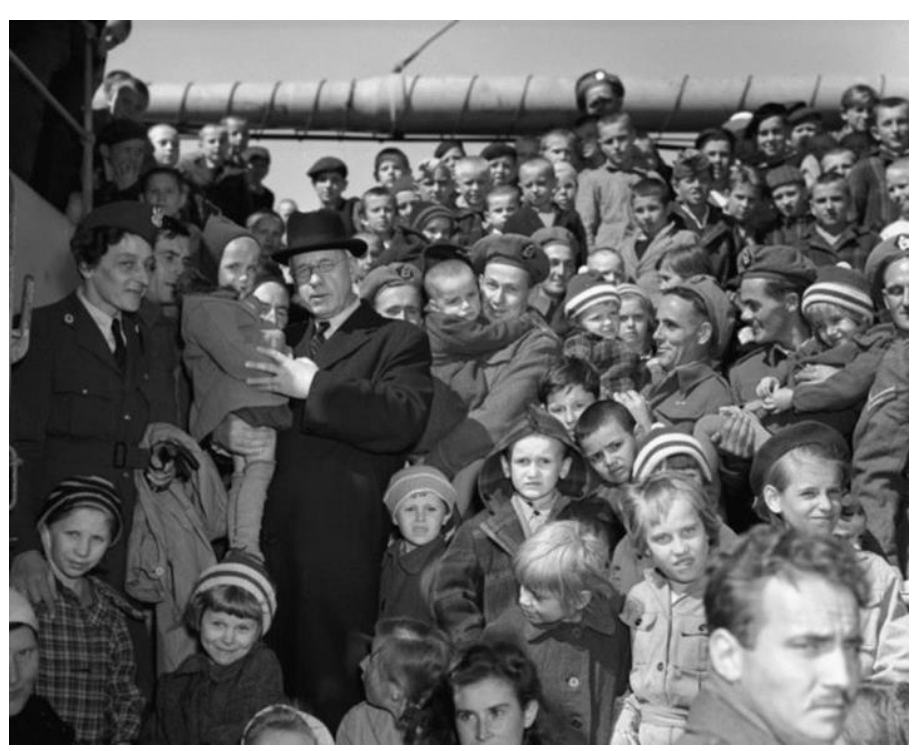
Polish children were orphaned or separated from family. In 1942, 20,000 of these children made the long journey from the Soviet Union to Iran and finally on to destinations as far afield as Mexico, India, Lebanon and Africa for safekeeping for the duration of the war, after which they were expected to return to Poland. ${ }^{38}$

Fig. 22. Countess Maria Wodzicka and Prime Minister Peter Fraser aboard the USS General Randall in Wellington Harbour, 1 November 1944, Ref: 1/2-003634-F Alexander Turnbull Library, Wellington, New Zealand.

The idea of bringing a group of these children to New Zealand came from Countess Maria Wodzicka, wife of the Polish consul General Count Kazimierz Wodzicki in 1943. She suggested the idea to Prime Minister Peter Fraser's wife Janet who soon shared it with her husband. ${ }^{39}$ The plan became a reality when the following year, on 1 November 1944, a group of 733 displaced Polish

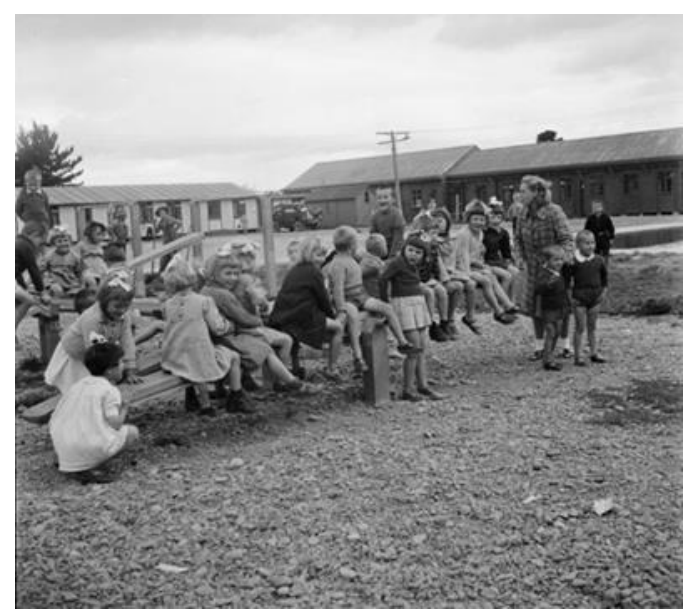

Fig. 23. Children in play area of a Polish refugee camp in Pahīatua, 1945. Pascoe, John Dobree, Ref: 1/4-001376-F. Alexander Turnbull Library, Wellington, New Zealand.

\footnotetext{
${ }^{37}$ Manterys et al., New Zealand's First Refugees, back cover.

${ }^{38}$ Manterys et al., 362.

${ }^{39}$ Manterys et al., 25.
} 
children and their 105 guardians arrived in New Zealand aboard the American troop carrier USS General Randall. ${ }^{40}$ The Prime Minister and the Wodzickas, along with many Wellingtonians, were at the harbour to greet them.

The children and their caregivers, including the Polish Ursuline sisters, were transported by train from the Wellington Railway Station to accommodation in Pahīatua. The camp had previously housed foreign internees and watchtowers and barbed wire fences still encircled the camp, but new buildings were extended and erected to accommodate the children. The camp was run with military expediency; the children lived and were educated in this miniature Poland, with lessons, language, caregivers and culture traditionally Polish. ${ }^{41}$ The plan was to prepare them to assimilate back into Poland after the cessation of hostilities. But by February 1945, Poland had not gained independence and was under communist control, and the majority of the children and their caregivers preferred to remain permanently in New Zealand. They did so at the invitation of the New Zealand Government. ${ }^{42}$

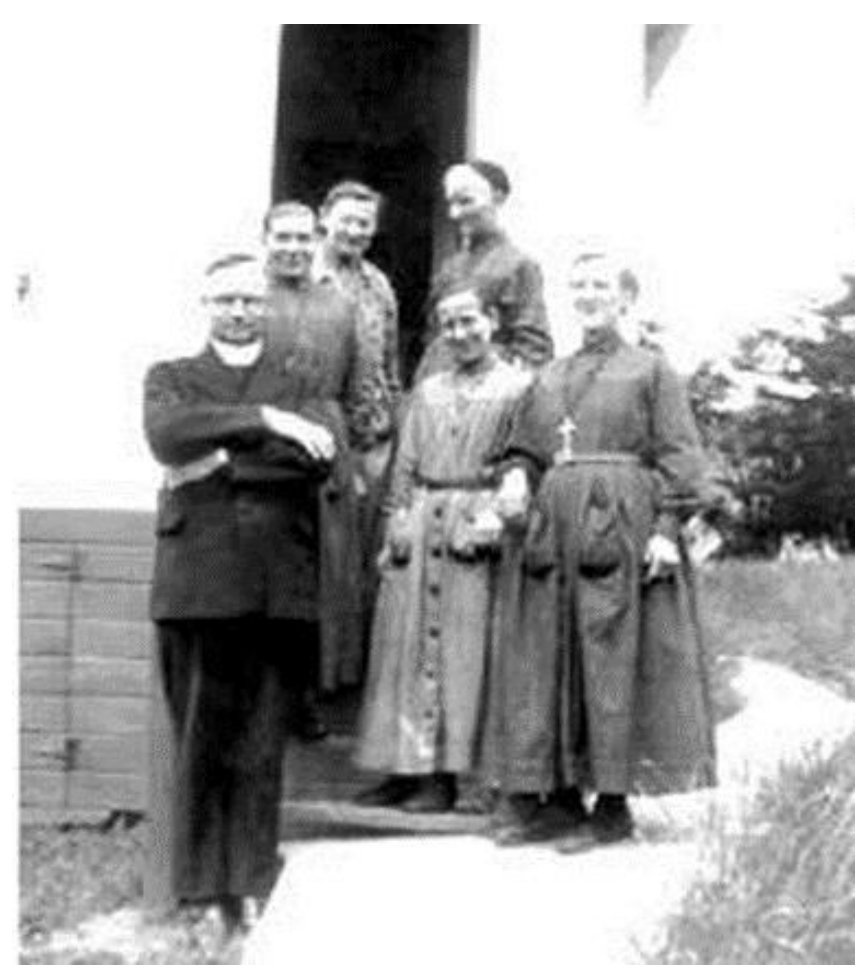

Fig. 24. Father Michal Wilniewczyc and Ursuline Sisters, At the Polish Boys Hostel in Wellington's Island Bay, Reproduced by permission from Józef and Stefania Zawada.

\footnotetext{
${ }^{40}$ Manterys et al., 7.

${ }^{41}$ Manterys et al., 25.

${ }^{42}$ Manterys et al., 26.
} 


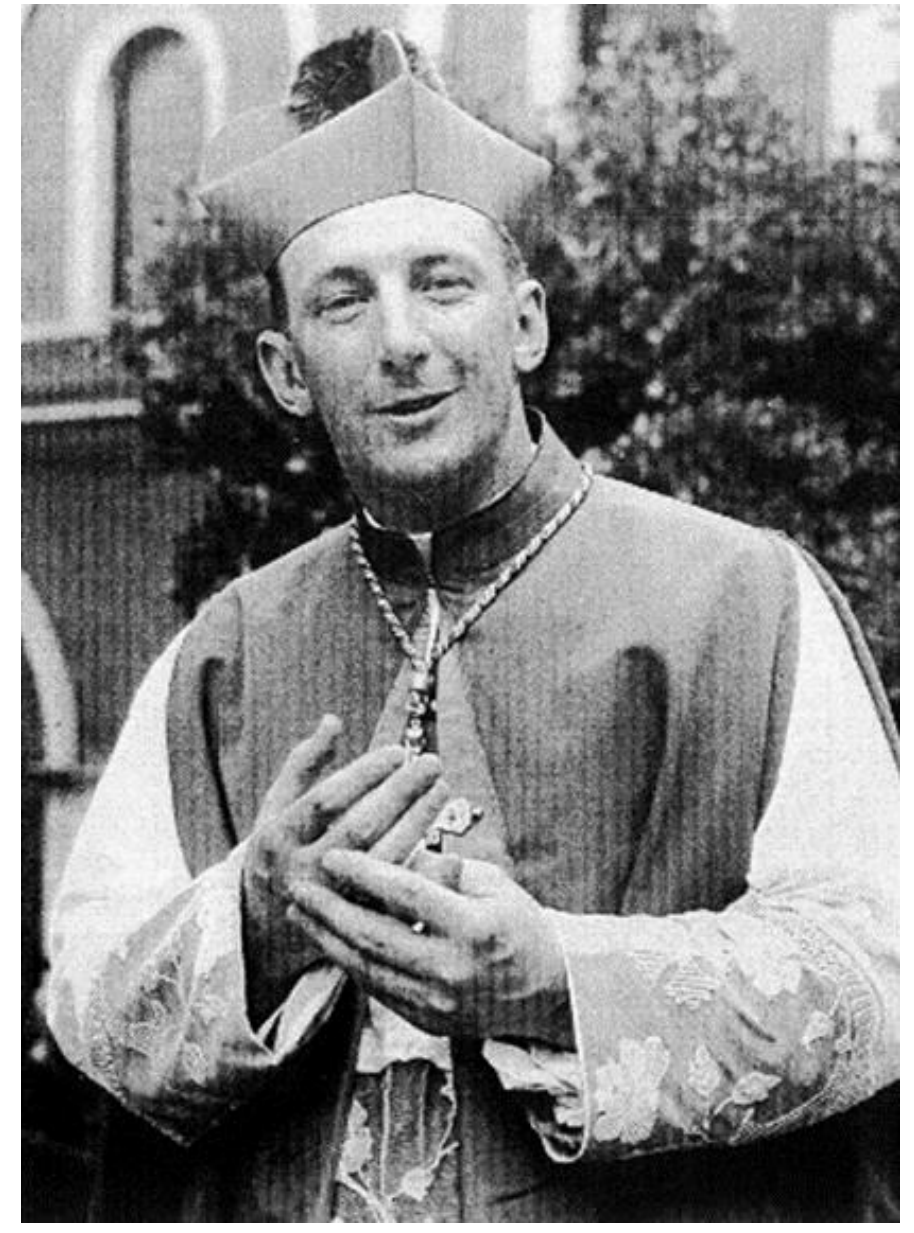

Fig. 25. Father John Kavanagh

Photograph courtesy of the Wellington Archdiocesan Catholic Archive
Permanent accommodation needed to be found for them. This task fell to Father John Kavanagh, who was appointed as the children's legal guardian. He sought to liaise between the Bishop's curia and the New Zealand Government to secure suitable accommodation. ${ }^{43}$ In 1946 Father Kavanagh made his first purchase to this end, a two-storey house in 167 Clyde Street in Wellington's Island Bay to establish a Polish boys' hostel. He installed the Ursuline Sisters (Urszulanki) Monika Alexandrowicz and Imelda Tobolska, who had cared for the boys since their exit from Poland. Forty boys from the Pahīatua Camp were placed in their care. ${ }^{44}$ Father Kavanagh then turned his attention to finding suitable accommodation for the girls.

He explored many options in the Wellington area and settled on Ngaroma. With its grand proportions, location, many spacious rooms and extensive garden, Ngaroma was in many ways ideal. There was some initial disagreement about the purpose of the hostel. Father Kavanagh wished to accommodate a mix of New Zealand and Polish girls, catering exclusively to young women working in the city. ${ }^{45}$ However, the Ursuline Sisters envisaged that the property would serve both as a hostel for the Polish girls leaving the Pahīatua camp, providing a very Polish and Roman Catholic environment for those both still at school and those in employment, but also a convent and novitiate for their order, the Polish Ursuline

\footnotetext{
${ }^{43}$ Manterys et al., 336.

${ }^{44}$ Manterys et al., 336.

${ }^{45}$ Manterys et al., 340.
} 
Sisters. ${ }^{46}$ After much discussion, including the presentation of a petition to members of parliament, the Sisters eventually prevailed. ${ }^{47}$ The Catholic Archdiocese of Wellington settled the purchase of the property, with the help of a subsidy from the New Zealand Government, on 8 December 1947- a day already auspicious to a Catholic community celebrating the Virgin Mary’s Immaculate Conception. ${ }^{48}$

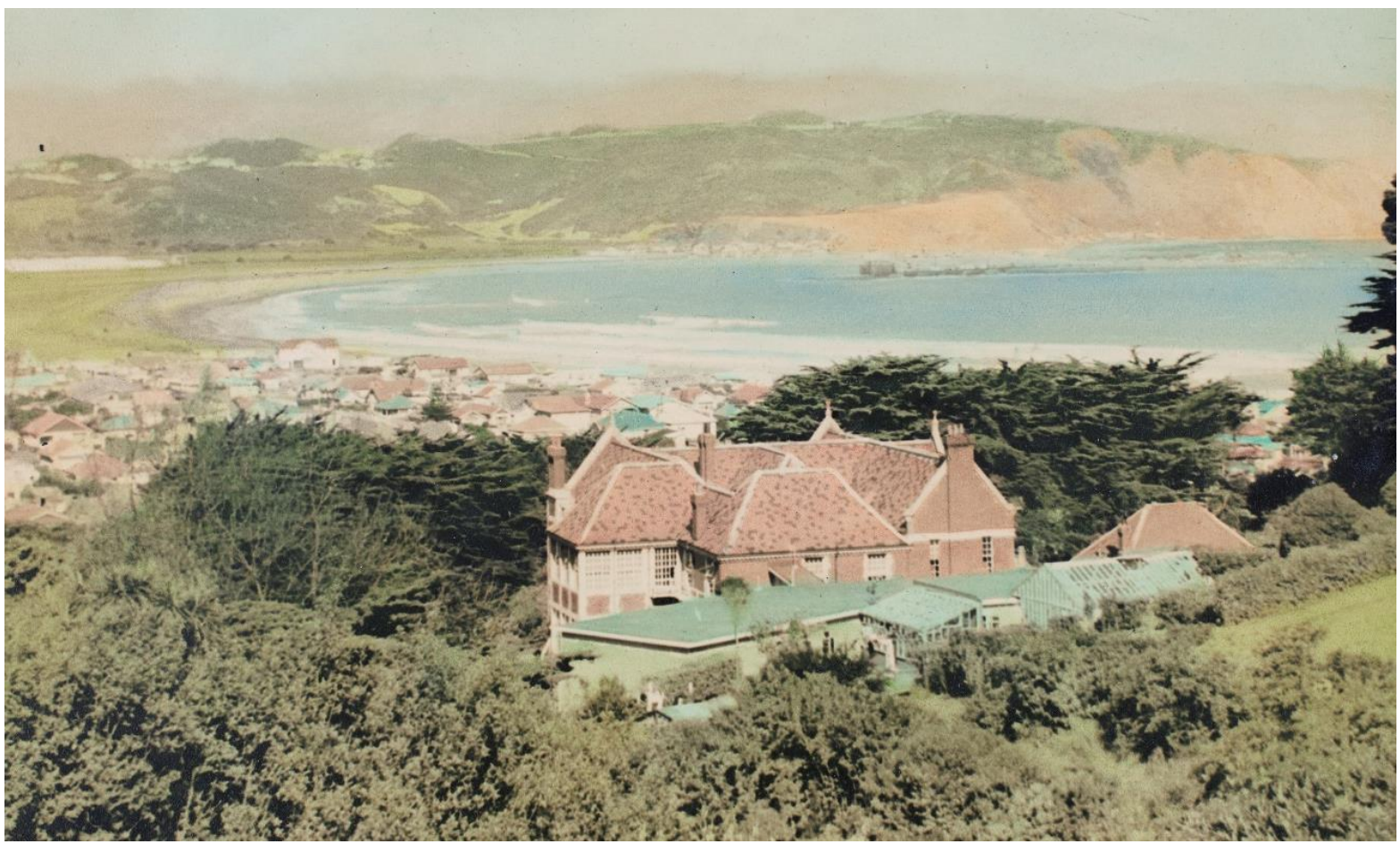

Fig. 26. Ngaroma, by then known as 'The Polish Girls' Hostel', overlooking Lyall Bay. The green annexe extension visible at the rear, c.1950s, PA1-o-1908-02-01 Album of hand-coloured photographic prints of chiefly Wellington scenes, Alexander Turnbull Library, Wellington, New Zealand.

46 "The Ursuline Sisters Come to Kilbirnie," 1.

47 "The Ursuline Sisters Come to Kilbirnie," 1.

48 "The Ursuline Sisters Come to Kilbirnie," 1. 


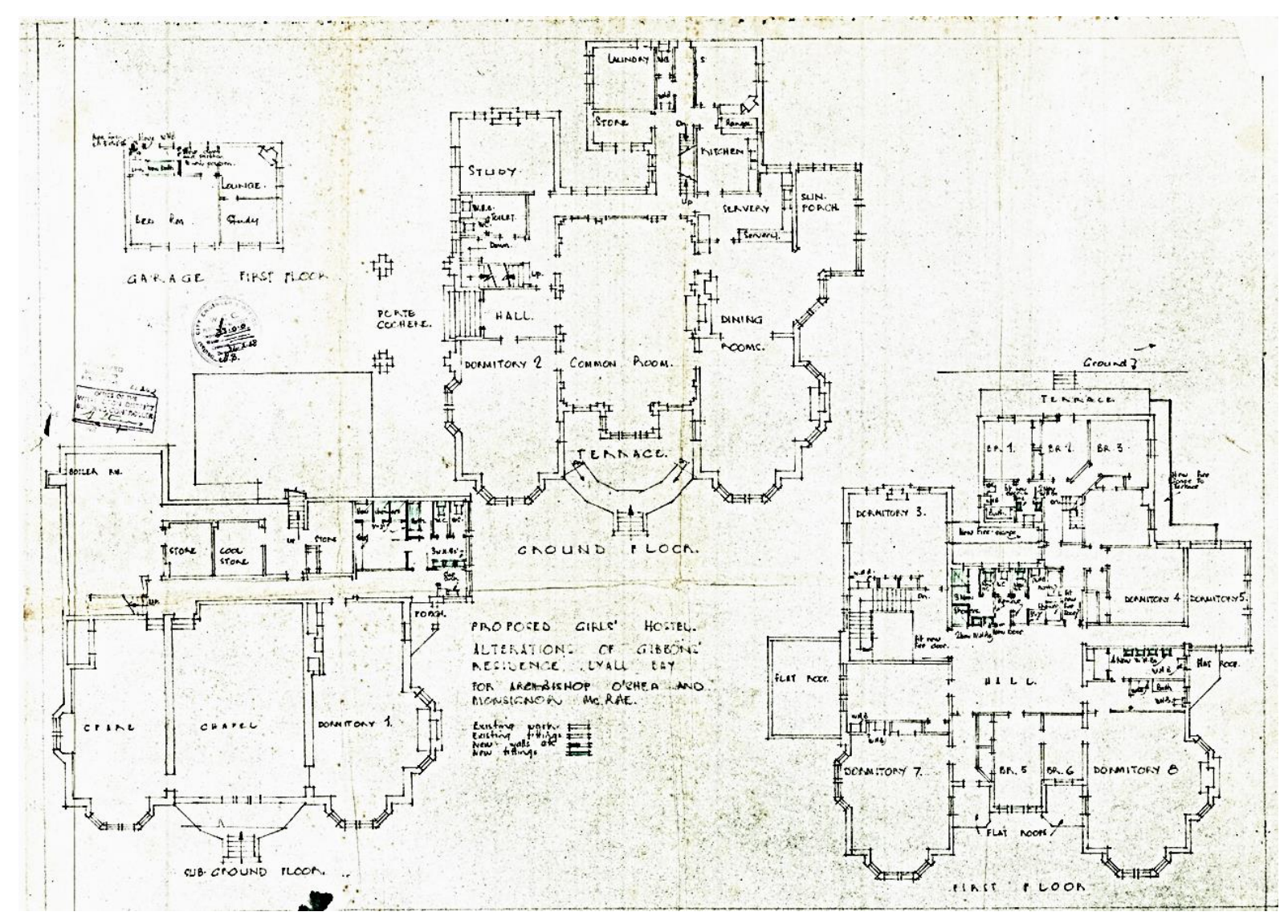

Fig. 27. The Plan of Ngaroma showing proposed alterations to the bathrooms to accommodate the girls, July 1945, Wellington City Archives, [00056:369:B28357]

Work was undertaken to adapt Ngaroma. It was initially anticipated that there would be room for 80 girls from the Pahīatua camp, who would be cared for by sisters Agustyna Sobczak, Imelda Tobolska, Marcina Maślak, Bernarda Brennan and Monika Alexandrowicz. ${ }^{49}$ The bathrooms in the main building were reconfigured and enlarged to meet the needs of the girls. ${ }^{50}$ A chapel was created in the central room of the lower level where the sisters and their charges could regularly attend mass - the first of which was celebrated by the Polish chaplain Father Leon Broel-Plater. ${ }^{51}$ In 1947 it was planned to erect an old army steel hut on the property as temporary dormitory accommodation for the novitiate. It is unknown if this became a reality. ${ }^{52}$ To provide further accommodation, in April 1948 a V-shaped single-level building on the hillside at the rear of the main building was constructed. Called 'the annexe',

\footnotetext{
49 "The Ursuline Sisters Come to Kilbirnie," 1.

${ }^{50}$ Wellington City Archives, [00056:369:B28357]

51 "The Ursuline Sisters Come to Kilbirnie," 1.

52 Wellington City Archives, [00056:345:B26649]
} 
it provided basic accommodation in 12 additional bedrooms and a single shared bathroom.

The entire structure was linked to the main building by a covered way. ${ }^{53}$

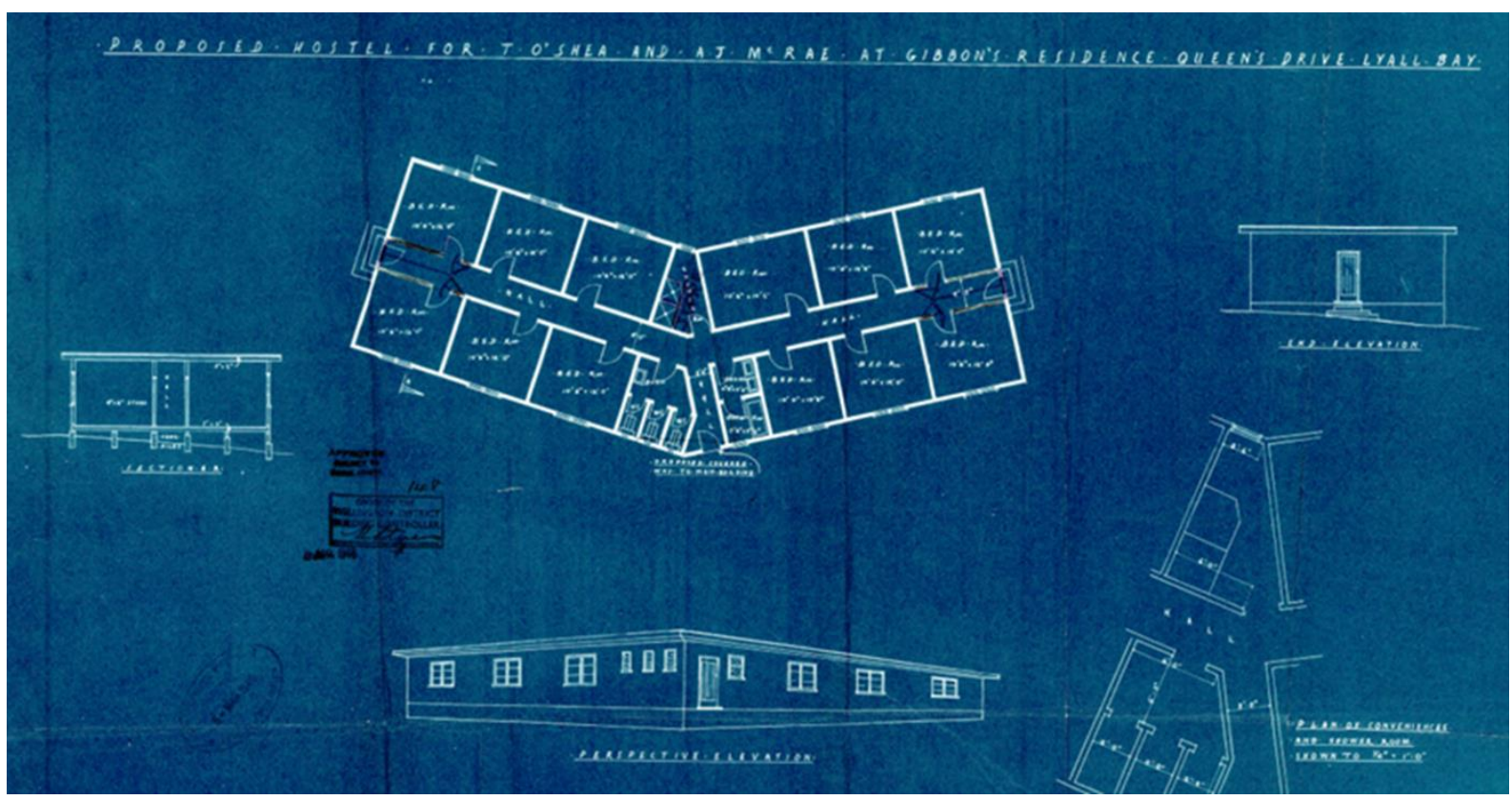

Fig. 28. The annexe at the rear was built to accommodate more girls. Wellington City Archives, [00058:789:C35485]

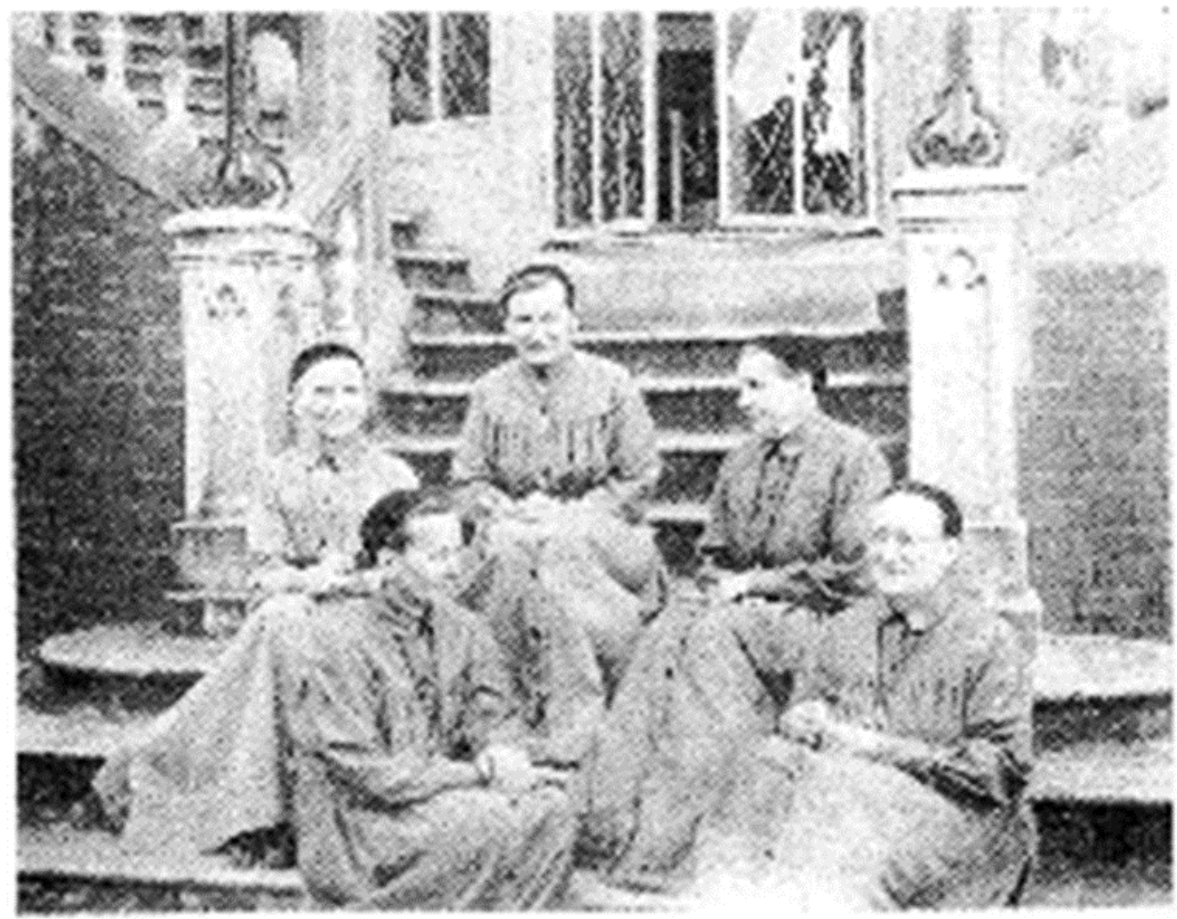

Fig. 29. The Ursuline Sisters at Ngaroma, Reproduced by permission from Holy Trinity Church, Jubilee 1919-1969. Issued by the Parish Council, St Patricks Parish, Kilbirnie, New Zealand, in commemoration of the 50th Anniversary, (Wellington: Futuna Press, 1969), 30.

${ }^{53}$ Wellington City Archives, [00058:789:C35485] 


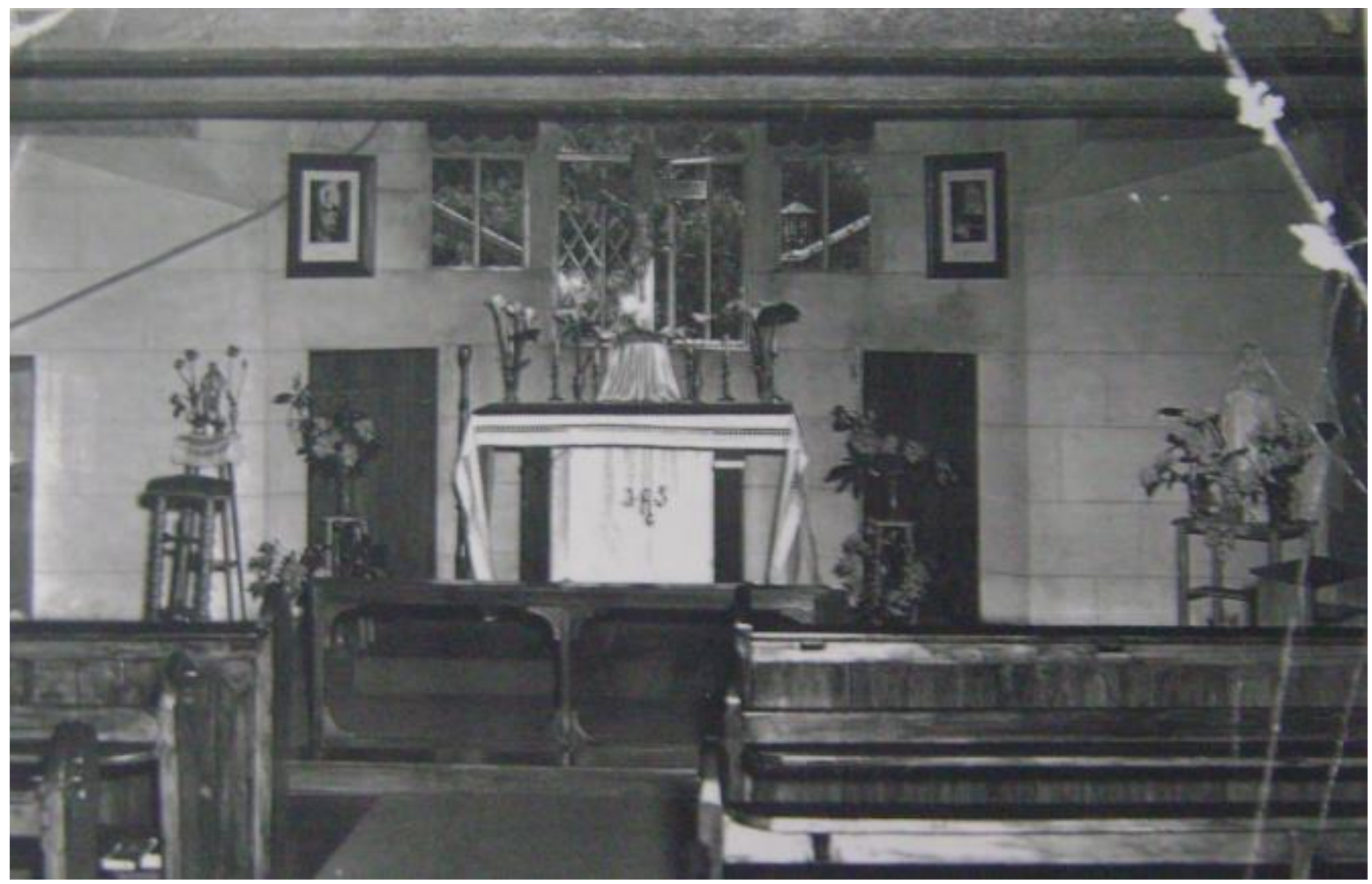

Fig. 30. The chapel in the basement where the community celebrated mass. Reproduced by permission from Józef and Stefania Zawada.

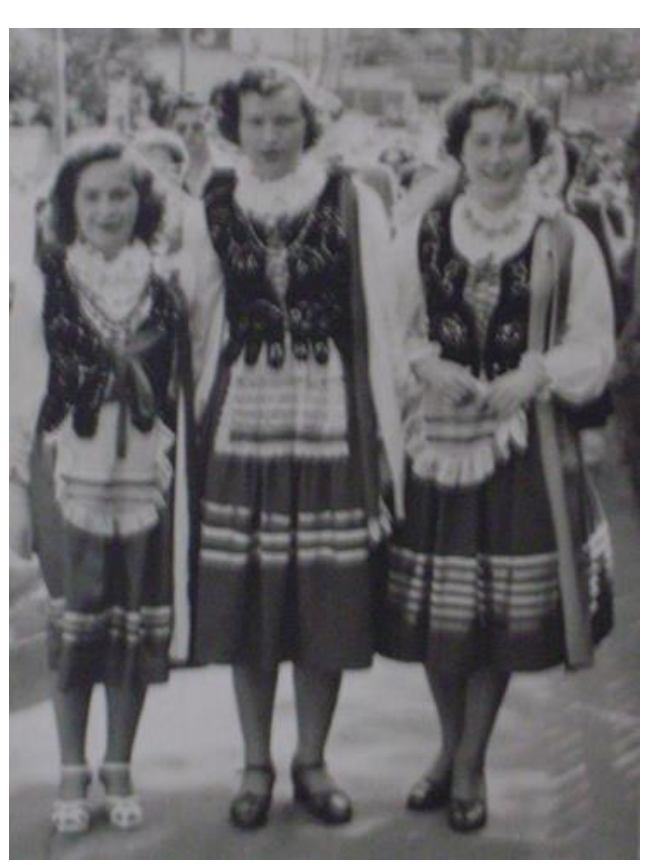

Fig. 31. Polish girls in traditional dress c. 1953 . Reproduced by permission from Józef and Stefania Zawada.
Ngaroma came to be known to the Wellington Polish community as the 'bursa' (hostel). The younger girls attended local Catholic schools in Kilbirnie and the city, and a few of the older ones attended Victoria University. Others worked in factories or undertook secretarial work in the city. On the weekends, the older girls played basketball or tennis on the court by the drive, walked down to Lyall Bay, sewed themselves dresses, put on theatrical productions or hosted dances to which the boys from the Island Bay Polish hostel and Polish ex-soldiers were invited. One of these girls later reminisced that 'often you could hear somebody singing, practising the piano or playing the records'. ${ }^{54}$

\footnotetext{
${ }^{54}$ Manterys et al., New Zealand's First Refugees, 342-43.
} 
The original Polish girls grew older; some left to marry, others to look for 'prywatki' (private quarters) in flatting situations in the city. ${ }^{55}$ There were still ex-Pahiatua girls at the hostel, which included girls coming to stay during their boarding school holidays, but also a small crèche caring for the children of former Ngaroma girls working in the city. Two elderly Polish women with no family also lived there in exchange for assistance running the hostel. ${ }^{56}$ With the permission of their superior in Poland, Sister Alexandrowicz invited her teacher sister, Jadwiga Alexandrowicz to join the group for additional help. ${ }^{57}$

Slowly the ethnic breakdown of the hostel's residents changed. By 1952 Ngaroma was home to children who were from increasingly diverse backgrounds; there were Russian, Irish, Yugoslav, Italian, Hungarian and both New Zealand European and Māori children. ${ }^{58}$

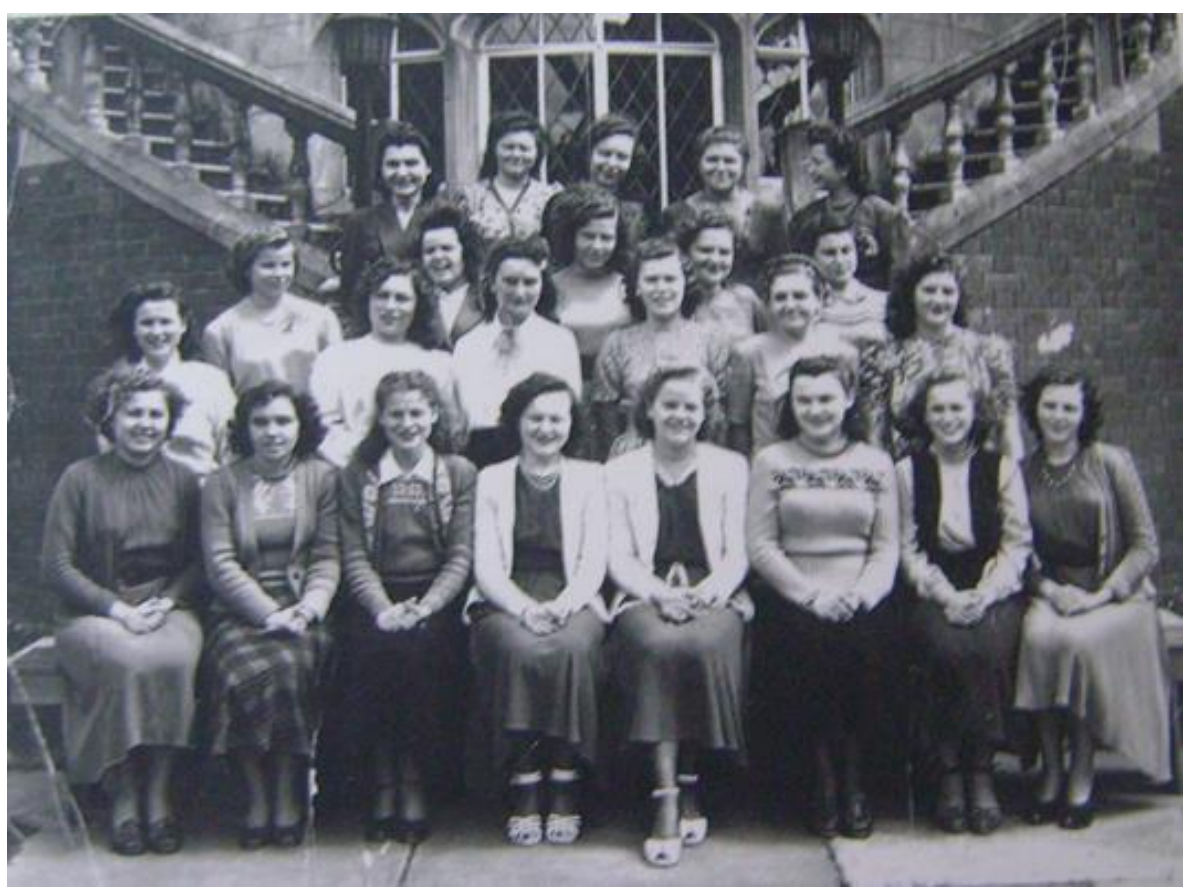

Fig. 32. The older girls who worked in the city, c. 1949. Reproduced by permission from Józef and Stefania Zawada.

Some of these

children were orphans or had unwell or overwhelmed parents, others were from broken homes. ${ }^{59}$ Despite these changes the sisters strove to maintain the Catholic values and character of the place and Polish continued to be the main language spoken by its residents.

\footnotetext{
${ }^{55}$ Manterys et al., 344.

${ }^{56}$ Julia Mary Moriarty, Jubilee 1919-1969. Issued by the Parish Council, St Patricks Parish, Kilbirnie, New Zealand, in Commemoration of the 50th Anniversary, September 14-21,1969 (Wellington: Futuna Press, 1969), 32.

${ }^{57}$ Manterys et al., New Zealand's First Refugees, 344.

${ }^{58}$ Manterys et al., 344.

${ }^{59}$ Moriarty, Jubilee 1919-1969, 32.
} 


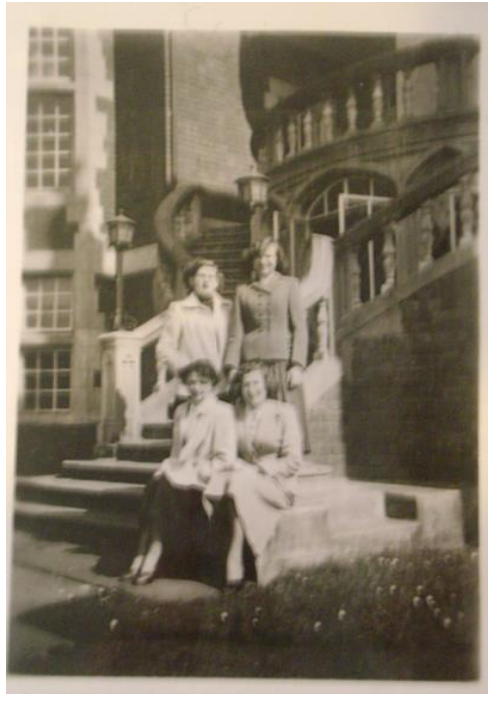

Fig. 33. Polish girls outside Ngaroma, c. 1953.

Reproduced with permission from Józef and Stefania Zawada.

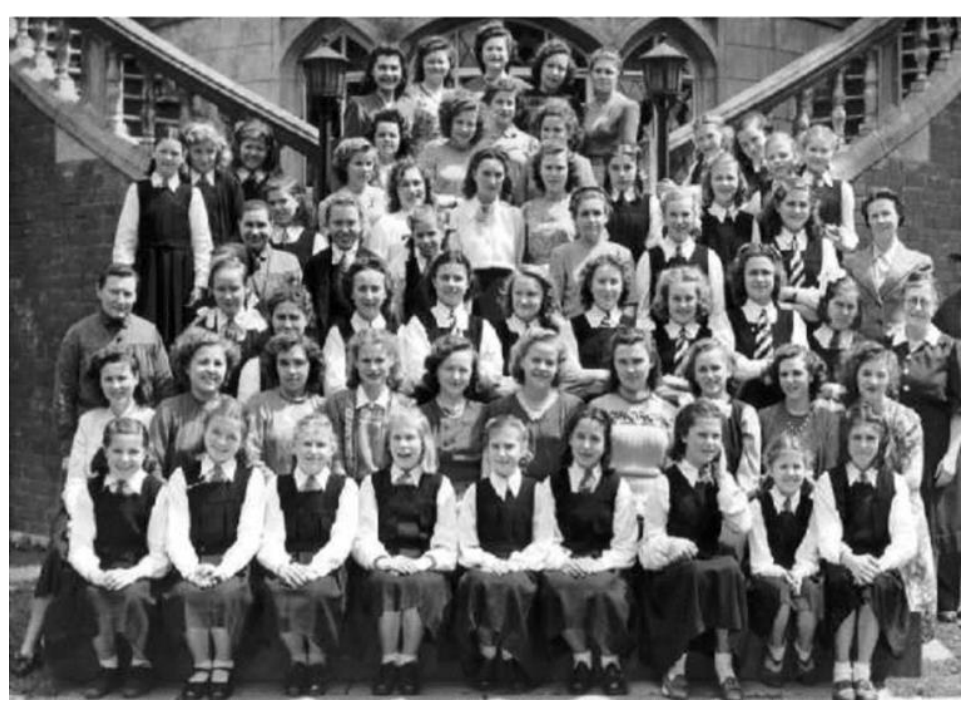

Fig. 34. The Ngaroma girls, c.1949.

Reproduced with permission from Józef and Stefania Zawada.

Eventually Sister Alexandrowicz wrote to her superior in Poland requesting more sisters to share the work of running the hostel, but the content of the letter she received back on 8 August 1957 was unexpected; the Ursuline Sisters were permanently recalled to the Mother House in Poland. ${ }^{60}$ The hostel closed its doors on 1 February $1958 .{ }^{61}$ On 9 March 1958, a

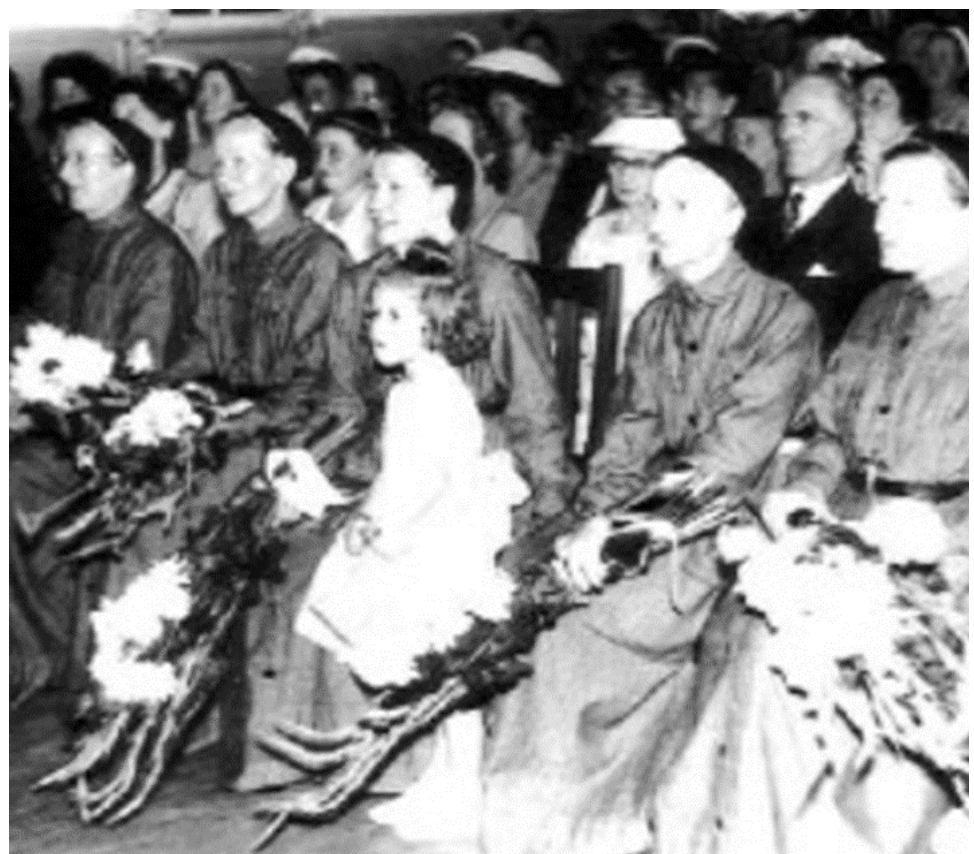

Fig. 35. The farewell at St Anne's, Newtown, Wellington, 9 March 1958. Reproduced by permission from Józef and Stefania Zawada. subdued farewell mass was celebrated at St Anne's Hall in

Newtown, where many representatives from the Catholic community and the Polish community gave speeches thanking the Ursuline Sisters for their tireless work caring for the children. ${ }^{62}$ Sister Alexandrowicz spoke eloquently, giving thanks to God, and acknowledging that the children had 'received the best' in the circumstances they found

60 “Papal Splendour,” Eastern Suburbs News, 24 April 1990, 2.

${ }^{61}$ Moriarty, Jubilee 1919-1969, 32.

${ }^{62}$ Manterys et al., "New Zealand's First Refugees," 346. 
themselves in in New Zealand. ${ }^{63}$ Sister Alexandrowicz, Sister Imelda, Sister Augustyna, Sister Marcina and Sister Brennan set sail aboard the ship Monowai several days later, on 13 March 1958, returning to uncertain times in Communist Poland. ${ }^{64}$

\section{St Vincent de Paul Displaced Persons' Emergency Emigration Hostel $(1958$ - 1967)}

In 1958 Ngaroma was established as an emergency hostel for refugees, at the request of the Immigration Division of the New Zealand Labour Department and with the support of Archbishop McKeefry, metropolitan of the Catholic Church. The Society of St. Vincent de Paul administered and ran the hostel, which was one of five in the Wellington area. Other hostels were located at Island Bay, Thorndon and Mount Victoria. Initially, the groups living there were primarily Hungarian. The influx was the result of the 1956 Hungarian uprising against communism. The New Zealand Government assisted financially with contributions eventually totalling over $£ 170,000 .{ }^{65}$ Of the 200,000 refugees seeking asylum worldwide, a total of 1,117 refugees arrived in New Zealand at the invitation of the government between 1956 and 1959. ${ }^{66}$ This was both a humanitarian response and a gesture of solidarity with the West which was entrenched in the bitter Cold War with the Russian government and its allies.

The first group of 66 Hungarians arrived at Whenuapai on 13 December 1956. They were later described as 'a weary, bewildered and white-faced group of people [who] disembarked, facing the ordeal of landing, unknown, in a new country with strange customs, different laws, and above all a foreign language' ${ }^{67}$ A welcoming speech by Minister of Immigration Ralph Hanan communicated through an interpreter, told them:

You have come to us in tragic circumstances, and many of you will have private sorrows. I hope that it will be a source of comfort and of inspiration to you to remember that you are surrounded by an enormous volume of goodwill...The

\footnotetext{
${ }^{63}$ Manterys et al., 347.

${ }^{64}$ Manterys et al., 346.

65 "Refugees From Hungary," Labour and Employment Gazette VII, no. 2 (May 1957): 15.

${ }^{66}$ Ann Beaglehole, "2. - Hungarians," Te Ara The Encyclopedia of New Zealand, accessed 3 August 2017, http://teara.govt.nz/en/hungarians/page-2.

67 "Refugees From Hungary," 15.
} 
Government and people of this country wish to share with you the good things which they enjoy. They confidently expect that you will come to love New Zealand as you have loved Hungary. ${ }^{6}$

Each was issued with $£ 5$ in cash, an English-Hungarian dictionary, and a pamphlet containing 'advice on how to enjoy their new freedom'. ${ }^{69}$ This first group, and those that followed, were a diverse assortment which included professionals, skilled and unskilled workers. Comprising single people and family groups, most of the new arrivals were processed at temporary reception centres at Mangere, Trentham and Woburn. ${ }^{70}$

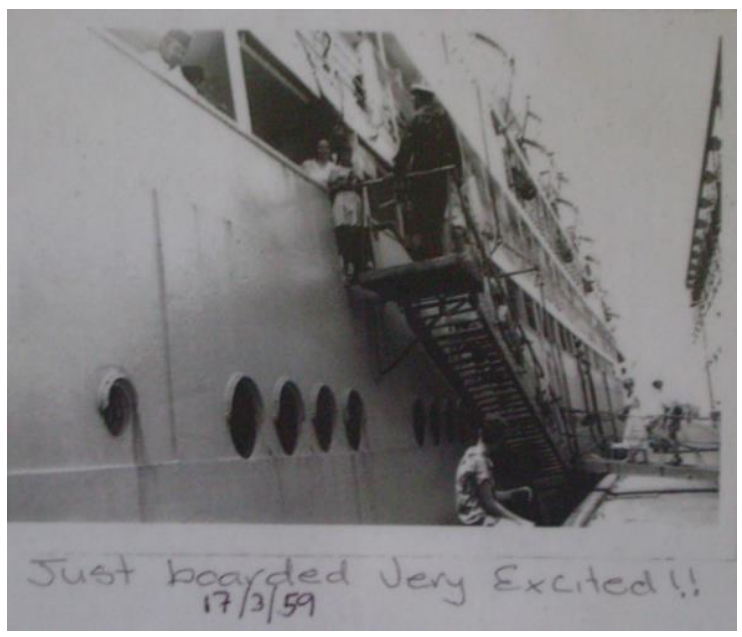

Fig. 36. Sibajak boarding for New Zealand, 1959. Reproduced with permission from Mary Papp.
A number of the refugees settled in the Wellington area and several were allocated accommodation at Ngaroma. The group that arrived on the Sibajak on 21 April 1959 was extensively reported on by the press. The group contained not only Hungarians but a minority of Yugoslavians and Ukrainians, described in the New Zealand Freelance at the time as 'unwanted', as they had been turned away by the strict migration requirements of countries like Australia and Canada because of poor health or physical handicaps; several had missing limbs or fingers, others had tuberculosis. The New Zealand Government had agreed to take 60 of these as a 'special gesture'. ${ }^{71}$ Aboard the Sibajak were 13 families and several single people, some of whom were to join the Hungarians who had emigrated earlier and were already living at Ngaroma. The press described the new arrivals as bewildered and emotional on disembarkation. 'Grown men and women burst into a flood of tears. There were emotional embraces with tears unashamedly down the faces of both welcomers and welcomed'. ${ }^{72}$

\footnotetext{
68 "Refugees From Hungary," 15.

69 "Refugees From Hungary," 16.

70 Beaglehole, "2. - Hungarians."

${ }^{71}$ Annabell Ross, "Unwanted," New Zealand Freelance, 29 April 1959, 3.

72 Ross, "Unwanted," 3.
} 


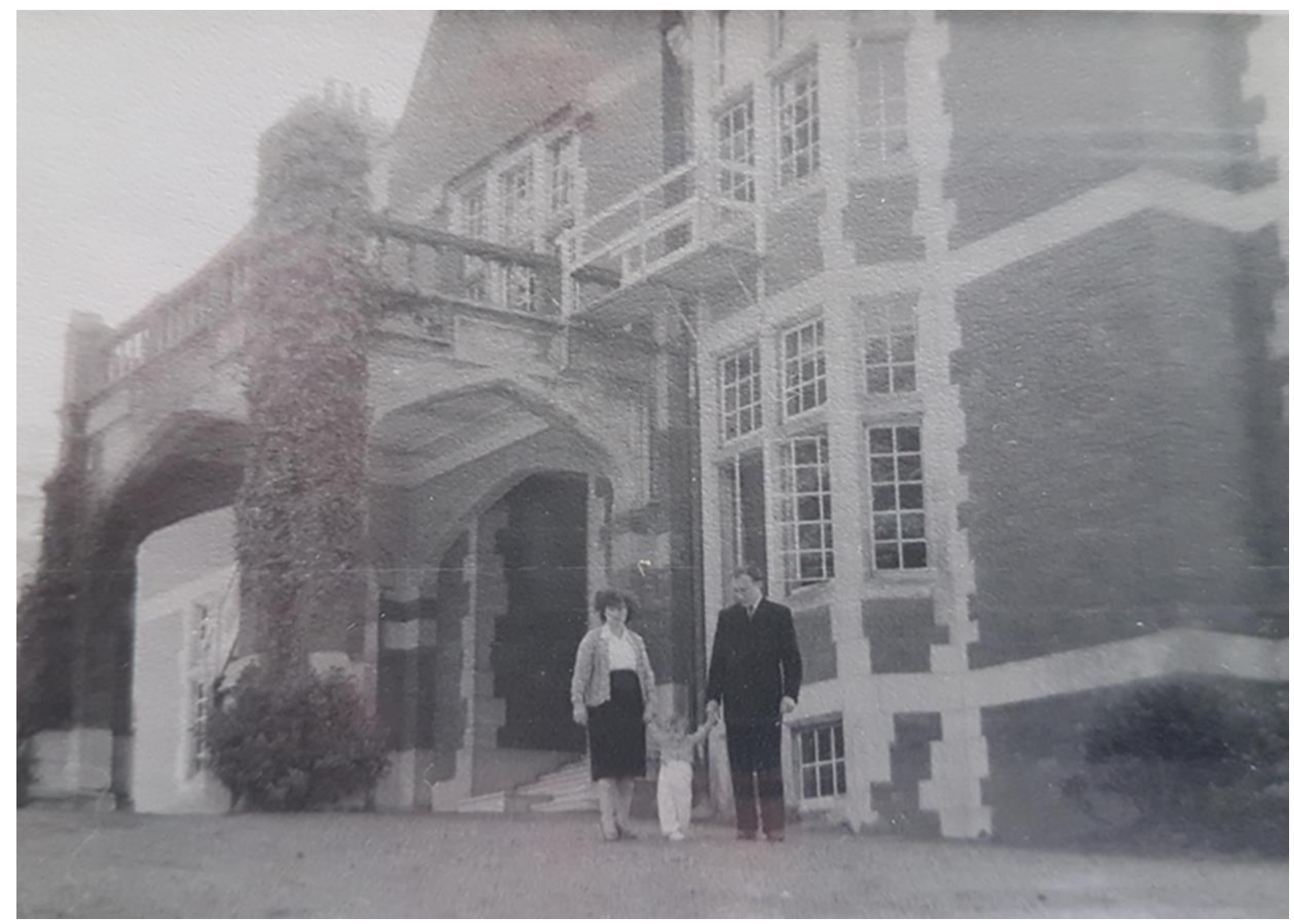

Fig. 37. Hungarian Fejos family outside Ngaroma. c. 1960. Reproduced by permission from Steve Fejos.
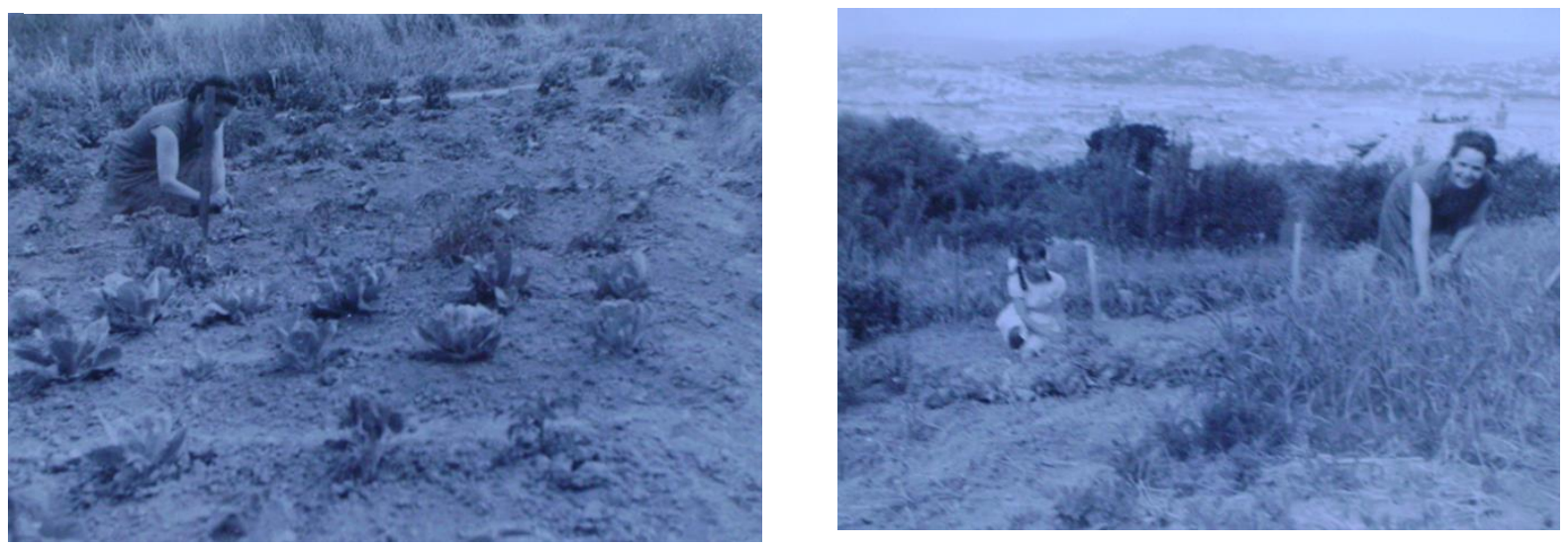

Figs. 38 and 39. Hungarian refugee Mrs Takacs and her daughter Mary tending to cabbages and garlic in their allotted plot at the rear of Ngaroma, Reproduced by permission from Mary Papp.

The refugees could stay at the hostel for a year or just over. At Ngaroma, still often referred to as the 'Polish Hostel', they shared accommodation, bathrooms, laundry and kitchensalthough each family undertook their own cooking. Many established small gardens at the 
rear of the property, cultivating vegetables and flowers. Residents began to tackle the English language and integrated into the local community. Despite their limited English, many benefited from the plentiful employment opportunities available in New Zealand in the 1950s. After a year or just over, most of the occupants moved to more permanent accommodation, many able to buy their first New Zealand home. ${ }^{73}$ By the late 1960 s most of

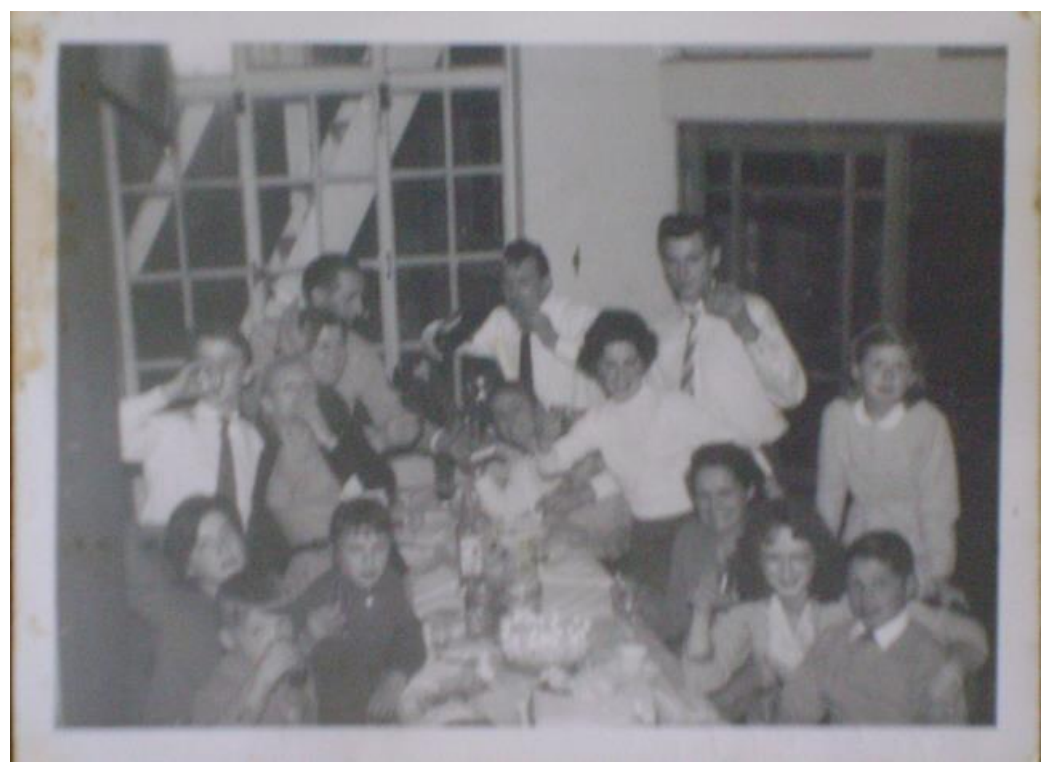

Fig. 40. Former refugees celebrating together at Ngaroma. Reproduced by permission from Mary Papp. the Hungarians, Yugoslavians and Ukrainians had moved out, but Ngaroma continued to be administered by the Society of St Vincent de Paul. Like the other Wellington properties which the Society administered, later offering accommodation to other refugee groups from a variety of backgrounds. The hostel was closed in 1967 for unknown reasons.

\section{Sisters of the Good Shepherd's Catholic Women's Hostel (1967-69)}

The next occupants at Ngaroma were the Sisters of the Good Shepherd, the New Zealand branch of a Catholic religious order founded in France in 1835 by Saint Mary Euphrasia Pelletier. Their mission and the focus of their work is to assist vulnerable women and children. They work particularly with women who are disadvantaged—striving to address the diverse issues and social repercussions of 'homelessness, unemployment, lack of education or work skills, being at risk of exploitation, lack of family support and nurture, addiction and poverty'. ${ }^{74}$ To this end, Saint Euphrasia urged her fellow sisters to 'pitch your tents on distant shores' and it was in response to this call that they first arrived in New Zealand in $1886 .{ }^{75}$

\footnotetext{
73 Beaglehole, "2. - Hungarians."

74 “Good Shepherd New Zealand," accessed 3 August 2017, http://www.goodshepherd.org.nz/about-us/ourhistory-in-new-zealand/.

${ }^{75}$ Catherine Kovesi, Pitch Your Tents on Distant Shores: A History of the Sisters of the Good Shepherd in Australia, Aotearoa/New Zealand and Tahiti (Caringbah: Playright Pub, 2006), 7.
} 


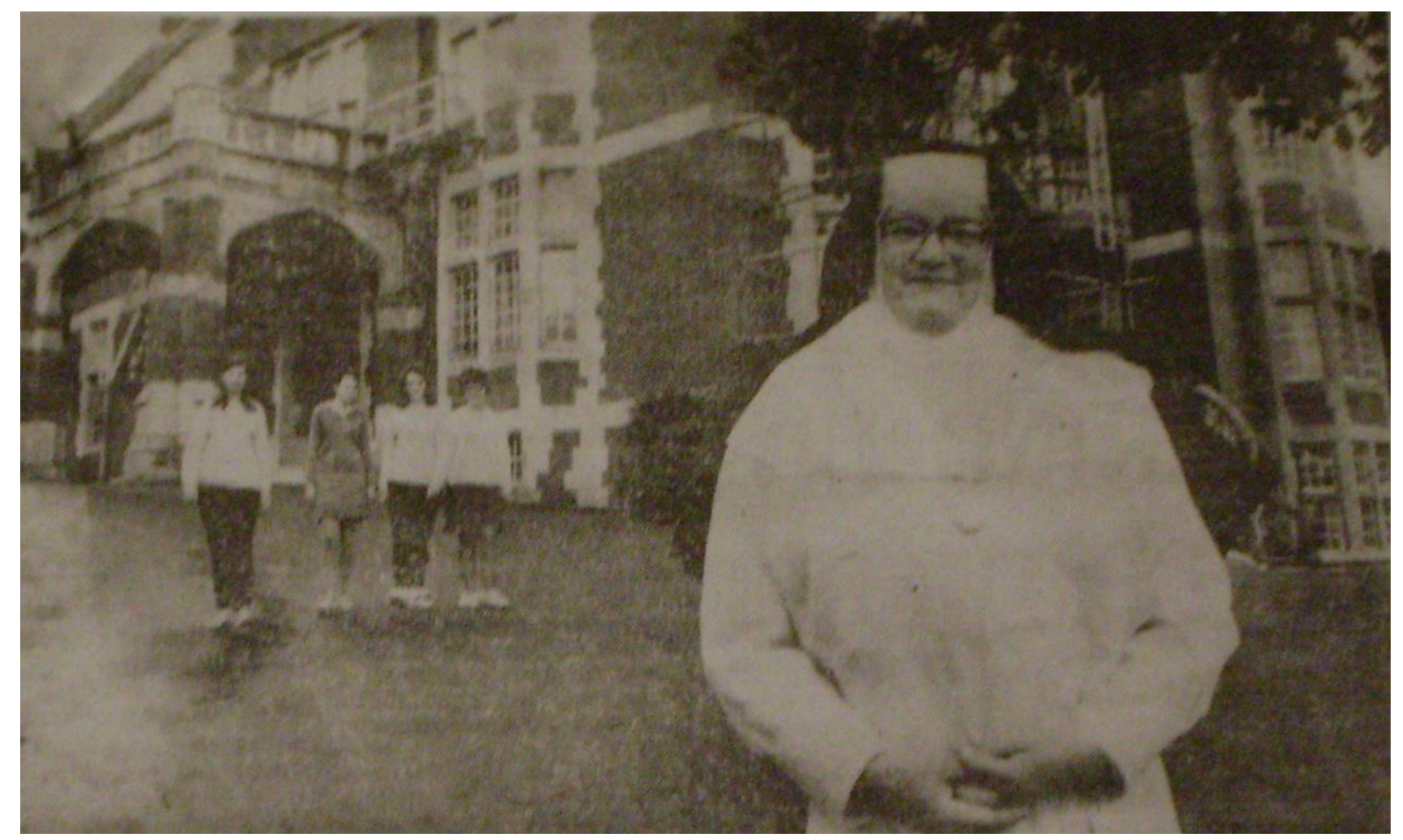

Fig. 41. Mother Euphrasia with Catholic girls boarding at Ngaroma. (Evening Post (microfilm), 11 August 1969), 13.

In Wellington they saw potential in Ngaroma. After some refurbishment they opened it in 1967 as a hostel for young Catholic women working in the city. ${ }^{76}$ The Reverend Mother M. St John Eudes led the group. ${ }^{77}$ Michael O'Meeghan writes that the women sought to create a 'spiritual centre, with the sisters available for counselling and guidance for outsiders as well as residents' ${ }^{78}$ This dream proved impractical as the modern young women chose independent flatting situations closer to the city centre, over shared dormitories in the suburbs. Soon the hostel was 'half full and running at a loss' and closed its doors in August 1969. ${ }^{79}$ The few young women remaining were forced to find other accommodation, and the Evening Post reported that they were saddened by the closure. ${ }^{80}$

\footnotetext{
76 "Papal Splendour," 2.

77 Wellington City Archives, [00009:437:9/283]

${ }^{78}$ Michael O'Meeghan, Steadfast in Hope: The Story of the Catholic Archdiocese of Wellington 1850-2000

(Palmerston North: Dunmore Press, 2003), 264.

${ }^{79}$ O'Meeghan, Steadfast in Hope, 264.

80 “Too Few Girls - Lyall Bay Hostel Closing Down,” Evening Post, 11 August 1969, 13.
} 


\section{Apostolic Delegation and Nunciature (1969-2015)}

In 1968 Pope Paul VI created a new apostolic delegation, a diplomatic mission of the Holy See, for New Zealand and the Pacific, and established its seat at Wellington. ${ }^{81}$ The first archbishop he appointed to this post was American Raymond Etteldorf, who arrived in Wellington in April 1969. ${ }^{82}$ He was given temporary accommodation at the Little Company of Mary convent beside Wellington's Athletic Park, and was formally received, with due ceremony, at St Mary of the Angels Church in Boulcott Street, where his appointment by the Vatican was officially proclaimed. ${ }^{83}$

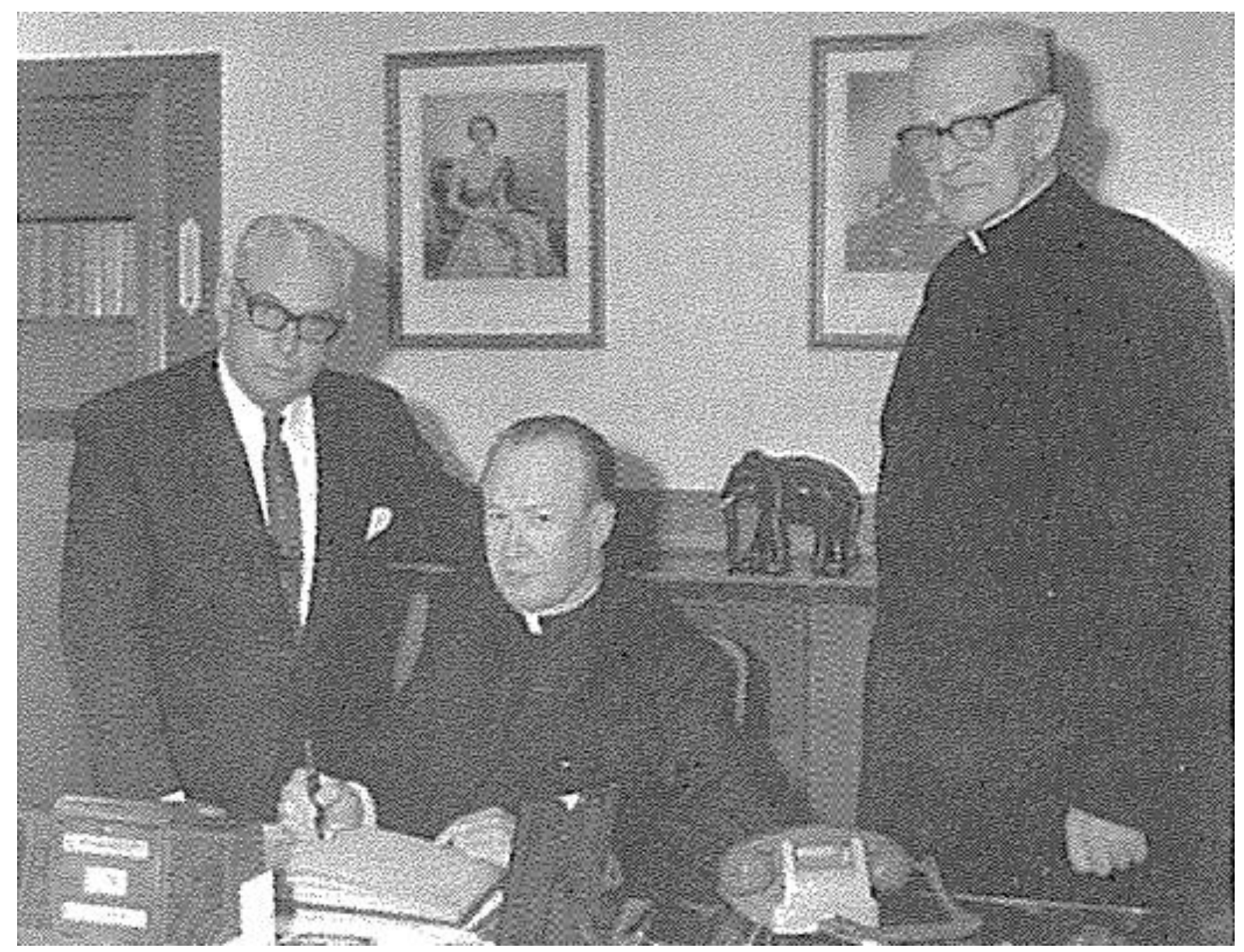

Fig. 42. Archbishop Raymond Etteldorf with Archbishop Peter McKeefry formally received by Prime Minister Keith Holyoake, 9 April 1969. Reproduced by permission of the publisher from Michael O’Meeghan, Steadfast in Hope: The Story of the Catholic Archdiocese of Wellington 1850-2000,

(Auckland: Dumore Press, 2003), 278.

\footnotetext{
81 “Apostolic Delegation For New Zealand, South Pacific,” The Catholic Weekly, 26 December 1968, 5.

82 "Apostolic Delegation For New Zealand, South Pacific," 5.

${ }^{83}$ O’Meeghan, Steadfast in Hope, 279.
} 
This new apostolic delegate required a residence, and Ngaroma was soon earmarked for this purpose. It was to be 'a small cornerstone of the Vatican empire thousands of miles from Rome' and by the following year, in 1970, it had been adapted for this new use. ${ }^{84}$ The interior was 'restored to something of its former state as the Hope Gibbons family's Wellington residence'. ${ }^{85}$ To achieve this, various unspecified 'interior rearrangements' had been undertaken and the coverings which had protected the walnut wall panelling in the downstairs reception rooms, while it was a hostel, had been removed. ${ }^{86}$ The spacious reception rooms on the ground floor proved an ideal place to host the various celebrations and gatherings stipulated by the Catholic calendar, and upstairs several of the bedrooms were repurposed as

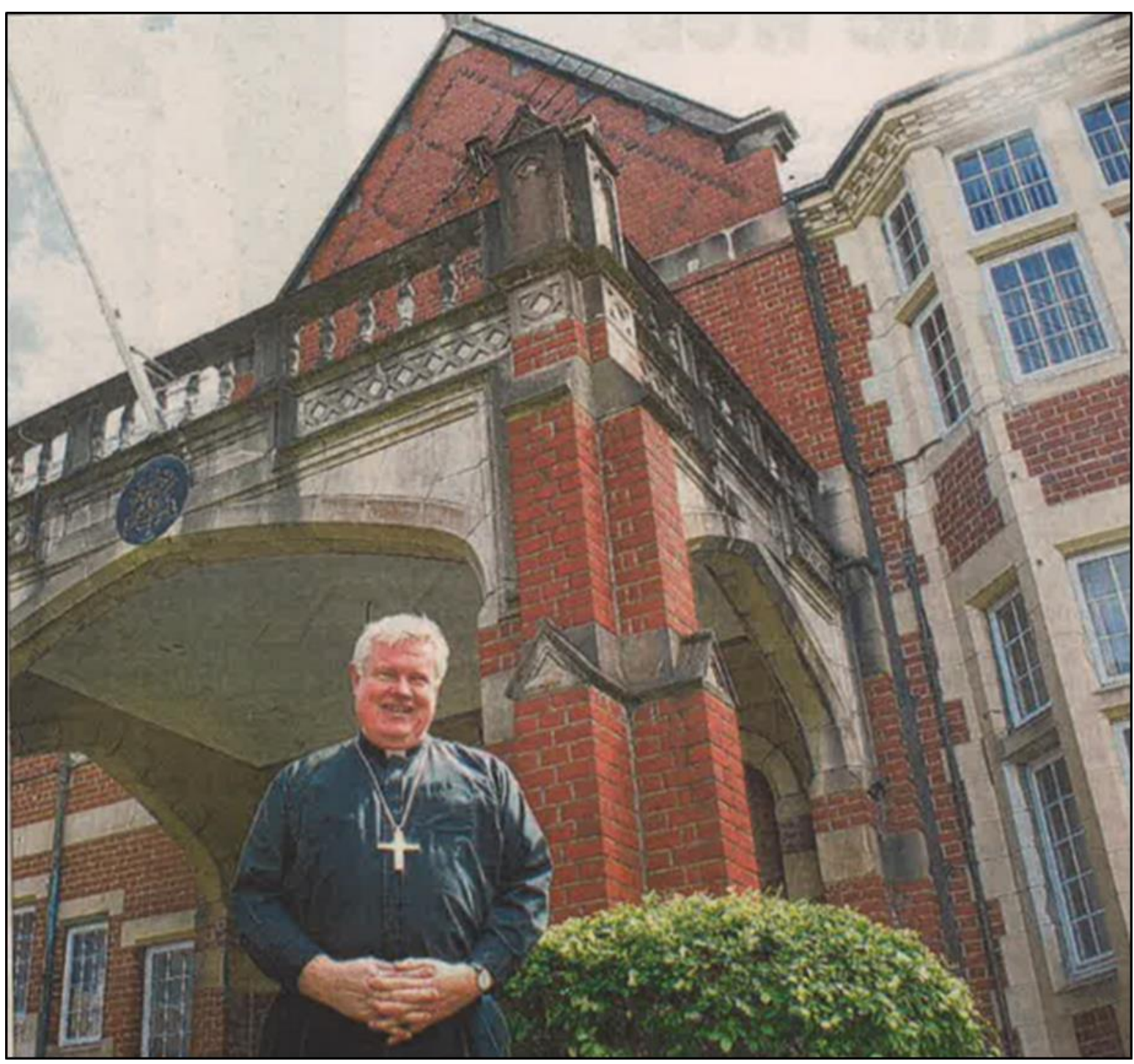

Fig. 43. American Archbishop Charles Balvo poses by the porte-cochère on the southern side of the building, (Cook Strait News, March 16, 2011), 4. Reproduced by permission from Wellington Suburban Newspapers.

\footnotetext{
84 "Papal Splendour," 2.

85 O’Meeghan, Steadfast in Hope, 279.

86 "The Nunciature Closes," 5.
} 
office space. They had no use for the rear 1948 dormitory extension and it was later demolished. ${ }^{87}$

After the apostolic delegation had been in residence at Ngaroma for just two years, the New Zealand Government moved to establish diplomatic relations with the Vatican. As part of these arrangements, in 1972, the ownership of Ngaroma was transferred from the Catholic archdiocese to The Holy See. ${ }^{88}$ By the following year the delegation was formally raised to the status of apostolic nunciature to New Zealand and the Pacific Ocean. This was a territory that, at the time, took in Cook Islands, Fiji, Western Samoa, American Samoa, Tokelau, Gilbert Islands and Ellice Islands, Republic of Nauru, Kingdom of Tonga, Tahiti, Marquesas Islands, New Caledonia, New Hebrides, Wallis and Futuna islands ${ }^{89}$ Formalities were concluded between the Vatican and then New Zealand Prime Minister Norman Kirk by 20 June $1973 .{ }^{90}$

The small community at Ngaroma soon came to be known locally as 'the Nuncio's'. Etteldorf was followed by a succession of Vatican-appointed archbishops: Angelo Acebi (from 1974); Antonio Magnoni (from 1980); Thomas White (from 1989); Patrick Coveney (from 1996), Charles Balvo (from 2005) and finally Martin Krebs (from 2013). ${ }^{91}$ The archbishops were assisted by an equally diverse succession of monsignors, and a rotation of Filipino sisters from the Binalonan-based order The Workers of Christ the Worker. The sisters cooked, cleaned and hosted various celebrations. They themselves occupied

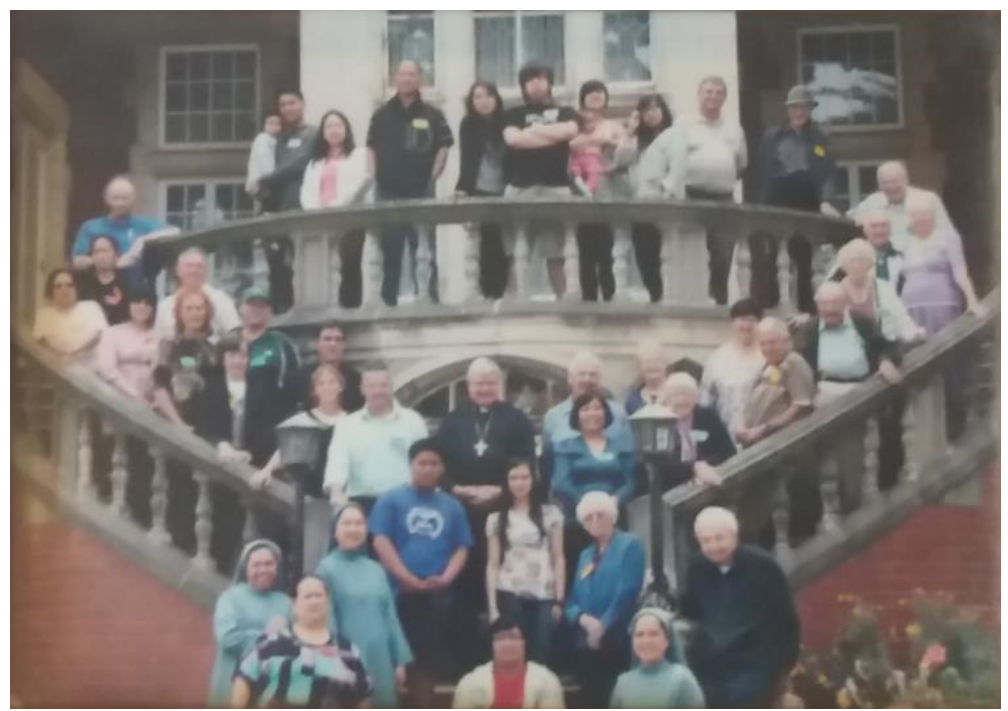

Fig. 44. Archbishop Charles Balvo with regular mass-attendees. Reproduced by permission from Carmel Fahey.

\footnotetext{
${ }^{87}$ O’Meeghan, Steadfast in Hope, 279.

${ }^{88}$ CT WN593/263

${ }^{89}$ O’Meeghan, Steadfast in Hope, 279.

${ }^{90}$ O'Meeghan, 279.

91 "The Nunciature Closes," 5.
} 
spartan quarters in the rooms above the separate garage building. In 1972 a room was added on the rear of the garage to provide them with an additional bedroom. ${ }^{92}$

Although few visitors were granted access to the main building, the basement chapel was open to the public, accessible through a door on the northern side of the building. A small but faithful number of the local Kilbirnie and Lyall Bay Catholic community met daily to attend early morning mass, often with the archbishop or the monsignor officiating, and the Filipino nuns also in attendance. Yet Ngaroma's most celebrated guest has been, without question, Pope John Paul II. He stayed at the papal nunciature during a 'whirlwind visit' on his Pacific pilgrimage in $1986 .{ }^{93} \mathrm{He}$ arrived in Wellington on 22 November and Figure 44 shows him at Ngaroma, photographed with New Zealand's Cardinal Williams and the other New Zealand bishops. He also met with Prime Minister David Lange, Leader of the Opposition Jim Bolger, and various members of the diplomatic corps the following day at the nunciature, before celebrating a public and well attended mass at Athletic Park. ${ }^{94}$

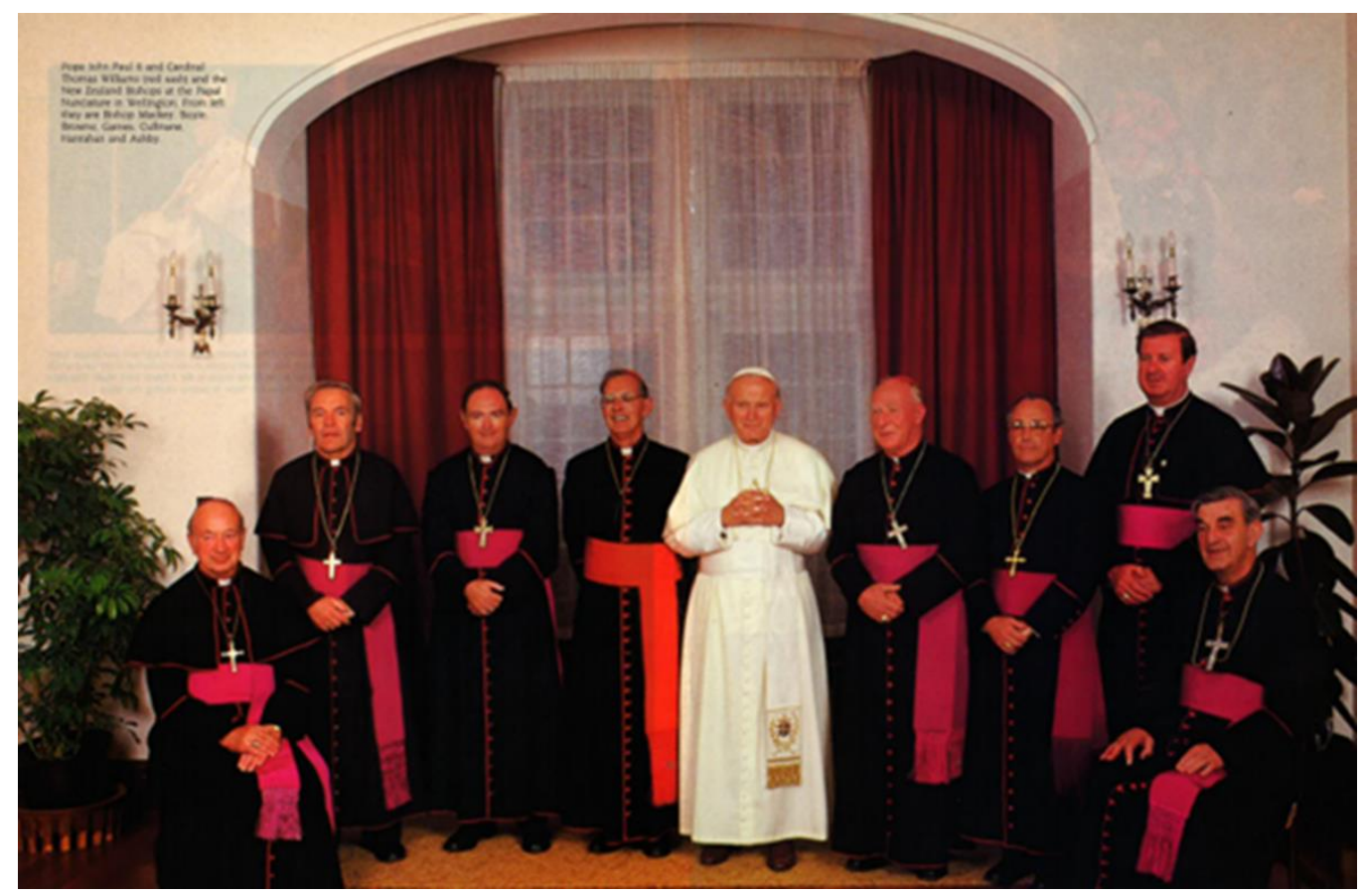

Fig. 45. Pope John Paul II and Cardinal Thomas Williams (red sash) and the New Zealand bishops at Ngaroma. From left they are Bishop Mackey, Boyle, Browne, Gaines, Cullinane, Hanrahan and Ashby. (Pacific Pilgrimage: a pictorial view of Pope John Paul II's visit Nov. 22-24, 1986, p.48-49. New Zealand Herald/NZME).

\footnotetext{
92 Wellington City Archives, [00056:348:B26808]

93 “Lyall Bay Papal Retreat during Whirlwind Tour," Western Suburbs News, 1 December 1986, 1.

94 Pacific Pilgrimage: A Pictorial View of Pope John Paul II's Visit Nov. 22-24, 1986. (New Zealand: Independent Newspapers, 1986), 48-49.
} 


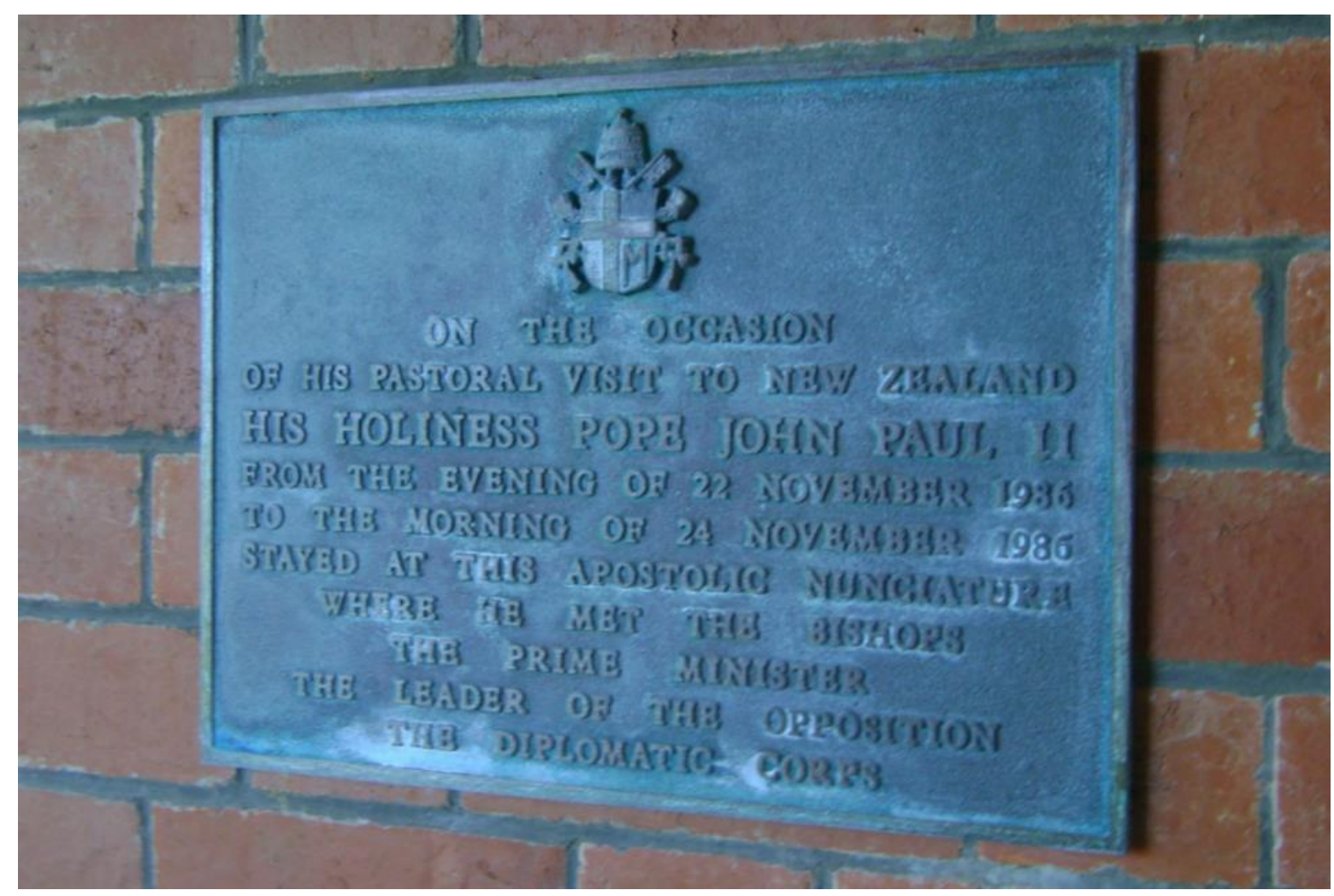

Fig. 46. Today a plaque by the entrance still commemorates Pope John Paul II's 1986 visit. (Photo by author)

By 2015 Ngaroma's future was under consideration. Rather than face the mounting expense of the maintenance and structural work required on the building, Archbishop Martin Krebs oversaw its sale and moved the papal nunciature to more modern new premises across the city in the suburb of Khandallah. With their departure, the long association between Ngaroma and the Catholic community ended, and with it, the early morning mass in the chapel.

\section{Private Ownership (2015)}

Ngaroma was purchased by a Wellington family in 2015, when it returned to use as a private residence. Renovations were undertaken throughout the house, most of which were primarily cosmetic, although the kitchen was upgraded and modernised. Rewiring, plastering and painting were also carried out, but major structural work has yet to be undertaken. It is likely that the building will eventually be listed on the New Zealand Heritage List Rārangi Kōrero. 


\section{Conclusion}

This chapter charts the history of Ngaroma and the people who have populated its story, by bringing together material drawn from a range of library and archival sources. The uses of the building have varied widely; originally a palatial family home, Ngaroma was then run as various hostels, an apostolic delegate and later as a papal nunciature before returning to private ownership. These uses are surprising in their diversity, encompassing groups from the prestige of the Vatican to refugees fleeing war-torn Europe. The narrative that the research establishes provides us with a basic understanding of the history of the house and its uses, and the surprising array of connections which make Ngaroma an unusually rich case study. In the next chapter, the building's history and significance are further explored using material gathered from nine oral interviews with people who have had a connection to the building. This will provide a context for assessing what information an oral history methodology can provide to further an understanding of this building, and in turn test how useful oral interviews are as a methodological tool in heritage studies. 


\section{Chapter Three - Analysis: The Oral Histories of Ngaroma}

We shape our buildings, and afterwards, our buildings shape us. —Winston Churchill

\section{Introduction}

The previous chapter established the history of Ngaroma drawn from library and archival sources. This chapter builds on this to look thematically at the material gathered by interviewing nine people with a connection to the house. Following Shrader's model, explicated in We Call It Home: A History of State Housing in New Zealand, I identify themes that arise from the interviews through a consideration of both the physical fabric and the social fabric of the building. ${ }^{1}$ I examine the stories told by the interviewees about their memories of the house. These memories are woven through with insight, humour, emotion and sensory recollections, which, taken together, allow us a dimension to our understanding of this unusual building that would be impossible to glean from visits to libraries and archives alone. Ngaroma was never just a house, it was a home and had an impact on the identities, aspirations and characters of those who lived there.

\section{Oral History and Physical Fabric}

When researching the history of any built heritage structure, a consideration of the fabric is standard practice, but the design and fabric of the building are an important part of what makes Ngaroma special. By applying oral history as a methodology in heritage studies we can learn about the story of Ngaroma's construction and see how people have shaped its physical fabric. To do this we can return to look at the original plans drawn up by Dawson in 1926, now housed at the Wellington City Council Archives. ${ }^{2}$ His plans for the residence give us a good understanding of the dimensions of the rooms and their original uses. But it is through oral history from Hope Gibbons' descendant, interviewee John Gibbons, that we can learn about the difficult economic times in 1930s New Zealand, and how this impacted on the procurement of imported materials for the construction of the house:

\footnotetext{
${ }^{1}$ Schrader, We Call It Home, 11.

${ }^{2}$ Wellington City Archives, [00056:9:B887]
} 
[The family] being in the car trade [...] no one could afford them anymore and prior to that the Model T boom had been going and they were building cars as fast as they could build them they were selling them and so they had done exceptionally well as the Ford distributing agent for New Zealand. And suddenly the cashflow stopped and the bank got a bit...very worried and so it is my understanding is that at that stage the Hope Gibbons Family Trust Office (which is still what I am Chairman of) was established... and the reason for its establishment was that the whole family-all the brothers - had to put all their assets in as collateral to save the building [...] because it hadn't been finished. All the fittings were imported [from the United Kingdom] ... all the doors, hinges and all the window fittings [...] hinges and automatic closers...all those things were on ships still coming [....]. They ordered them prior to the recession. Of course, ships took six, three months to get here. By the time you ordered them and got them built and shipped it could be at least that length of time and so there was a major concern and all the family had to basically put all their assets on the line for the bank and that saved the day [...]. The Trust Office was established to maintain the funding sources and it was many years later before the balances were written off. There was a sort of a ledger kept between all the families [...] to finish the house and to live in it. The rest of the family supported it for a number of years. Over the years that debt was paid off. ${ }^{3}$

This interview explains the financial conditions under which Ngaroma was planned and built and in doing so situates Ngaroma in the economic and social context of 1920s- and 1930sNew Zealand. It also gives us unique insight into Ngaroma's early history and illuminates how the Hope Gibbons descendants remember and tell their own family narrative.

Through oral history we can learn about both the physical structure of the rooms and their uses, but also gain an understanding of how the building itself is remembered today. Steve Fejos, born to Hungarian refugee parents at Ngaroma in 1959, was a small boy at the time, but recalled the expanse of the family's allocated room in the main building:

It was a lovely big room [...]. Our beds were partitioned off with some of those screens from the rest of the room. It was large enough to have a couch seating as well

\footnotetext{
${ }^{3}$ John Gibbons, interviewed by Miranda Williamson on 6 June 2017, Wellington.
} 
as a separate double bed for my parents. So, it was a large, large room. As a child, of course the memory is of it being larger as well. Each of the families had different rooms assigned to them. ${ }^{4}$

Fellow Hungarian refugee Mary Papp, who arrived at the house with her family shortly after Steve Fejos' family, also talked of the fabric of the house. To her, it was something from a storybook:

To me it was like living in a castle. It was gorgeous. [The room allocated to our family] was a huge room. There was a bathroom there that everybody shared that lived upstairs. The kitchen [...] was a communal kitchen with about three stoves in it. And dining room long tables that everybody sat at. ${ }^{5}$

There were less glamorous aspects of this romantic notion of life in 'a castle' - the downstairs rooms were very cold and Polish-born Maria Campbell described the basement dormitory as 'so cold [...] they used to call it the dungeon'. ${ }^{6}$ From Steve Fejos' visual perspective of his family's bedroom from his vantage point as a young boy; Mary Papp's comparison of the house to a child's storybook castle; to Maria Campbell's fanciful description of a castle's dungeon; all three of these interviewees make allusions to the perspectives and world-view as children — a time when the senses are critical for making sense of the world.

This thesis also seeks to establish if oral history can describe major changes to the fabric of the building and give context to any changes made. At Ngaroma the most significant alteration was the addition of an annexe at the rear of the building. This v-shaped 1948 dormitory extension was built to accommodate some of the older Polish girls studying at Victoria University of Wellington or working in the city. ${ }^{7}$ Later, the Society of St Vincent de Paul ran it as a refugee hostel between 1958 and 1967, the extension accommodated the most recent, primarily Hungarian, arrivals. They were later allocated a more comfortable room in the main building as these became available. Mary Papp described the annexe- 'they weren't flash. There was one toilet and bathroom for all those rooms $[\ldots]$. But there were only four of

\footnotetext{
${ }^{4}$ Steve Fejos interviewed by Miranda Williamson on 27 June 2017, Northland.

${ }^{5}$ Mary Papp interviewed by Miranda Williamson on 6 July 2017, Miramar.

${ }^{6}$ Maria Campbell interviewed by Miranda Williamson on 14 June 2017, Alicetown.

${ }^{7}$ Wellington City Archives, [00058:789:C35485]
} 
us sleeping in the room at that time. It was fine'. ${ }^{8}$ Mary Papp's interview shows that oral history can be useful when employed in conjunction with building plans to articulate and explain changes made to the fabric of a building.

Changes to Ngaroma's interior fabric was also recalled by the interviewees when questioned. The brevity of their responses indicates that few changes were made and that they were of minor importance. However, one memorable instance was in November 1986, when there was cause for a flurry of interior decoration at what was by then the Vatican's papal nunciature. The reason for this was Pope John Paul II's three-day visit, stopping over on his pilgrimage around the Pacific. While the local press was informed that there were no special preparations underway to prepare the nunciature, there was activity behind the scenes.

Gardener Chris Hampton recalled:

The Pope was coming so they were obviously redecorating inside with paint and all the rest and the main staircase from the main floor up to the first floor where the Pope's bedroom and the main reception area was had beautiful red carpet and one of the painters $[\ldots]$ dropped a can of white paint over the red carpet-and this was about two or three days before the Pope was due to arrive and [...] it took about two or three days until the Pope arrived to clean this paint. Because it was oil paint [...] I don't know how they did it, but they did get the paint off the carpet. You can imagine the panic that would be going on and I can just imagine the poor little Filipino nuns would have been out of their tree. ${ }^{9}$

Despite this minor setback in the preparations, the visit was considered a success and today a plaque by Ngaroma's main entrance commemorates this visit. This excerpt paints a vivid visual picture. We can imagine the contrast of the red carpet and white paint and almost hear the cacophony of the tradesmen.

The water tower, garage and tennis court are curtilage to the fabric at Ngaroma. The water tower and garage also were designed by Dawson; they are in keeping with the design and fabric of the main building, with the same red brick and grand proportions. The garden-

\footnotetext{
${ }^{8}$ Mary Papp, 6 July 2017.

${ }^{9}$ Chris Hampton, interviewed by Miranda Williamson on 27 April 2017, Miramar.
} 
though not strictly the fabric of Ngaroma-was also an important part of the setting of the structures there. The water tower, though today largely obscured by vegetation, was a feature of the property, admired by visitors and sometimes scaled for a panoramic view of the wider area. Mary Papp remembered:

[We were not allowed to climb it] but we did [anyway]. At the back, there was a huge piece of land $[\ldots]$ and anybody that wanted to could start a little garden, they had a little plot and they could grow-you know like garlic which you couldn't buy in 1960s New Zealand. They all had their little own gardens and some people grew flowers $[\ldots]$. It was a magical place, absolutely lovely. ${ }^{10}$

The smell of garlic and fresh flowers emanate from this memory. Steve Fejos also remembered the Ngaroma grounds - the contrast of the dark surrounding vegetation. He says it was:

Totally our place [...]. I remember the driveway. Remember the trees. Remember the backyard. As a young child feared a little bit: the bush — the dark bush and that sort of stuff as you can imagine but can also remember a lot of fun times on the tennis court and that area of the hostel [...]. A very secure safe space because cars weren't too common so playing on the driveway was very accepted and very safe and very common. ${ }^{11}$

This excerpt captures some of the drama and emotion of childhood adventure. These sensory memories are bound up in their description of the grounds and the sense of exploration and adventure enjoyed there by the refugee children in the late 1950s and early 1960s.

As time passed, the fabric of the building began to decline. By 2015, as the nunciature, it was in a poor state, with crumbling brick interior walls, rusting window frames and serious water damage, particularly in the basement. It needed major structural work, but the Vatican was unwilling to pay for it. The steady decline of the interior of the building was particularly noticeable to those from the local community attending daily mass. Chris Hampton said:

\footnotetext{
${ }^{10}$ Mary Papp, 6 July 2017.

${ }^{11}$ Steve Fejos, 27 June 2017.
} 
There were always the plans of the nunciature moving because the building was falling into disrepair, it was going to need megabucks spent on it. It was too big for their needs, really, for two people living there and three Filipino nuns. ${ }^{12}$

This deteriorating state eventually prompted the sale of the building in 2015 , but today the physical structure of the building has yet to be strengthened and its vulnerability to earthquake damage is still the source of some comment.

The data generated from these interviews shows that oral history can be a useful source of information describing the physical fabric of a building. When prompted, interviewees recalled both the exterior and interior fabric of Ngaroma, and also described their memories of the grounds in which the building is situated. Despite the interesting material that questions about the physical fabric generated, the interviewees responses about physical changes were only recounted if the interviewer specifically asked about them. Interviewees showed little interest when describing these changes - as they preferred to reminisce about the social fabric rather than the physical fabric of Ngaroma.

\section{Oral History and Social Fabric}

We can now turn from looking at the physical fabric of the building and its curtilage to looking at its social fabric. In doing this we can test how oral history can be utilised as a methodology in heritage studies to understand the social fabric of a building. We will explore the trove of interviews from our case study building, Ngaroma, to hear their memories of the house, how it shaped the people who lived in and visited it and what it meant to them. Oral history can give us this unique understanding and insight, and we can add it to our understanding of the physical fabric to build up a fuller picture of Ngaroma and its unique history.

A theme pervading the interviews, was that for many of its diverse residents Ngaroma was a place of sanctuary and stability. For the primarily Polish and Hungarian refugee groups fleeing war-torn Europe, this was a welcome change from the uncertainty that had

\footnotetext{
${ }^{12}$ Chris Hampton, 27 April 2017.
} 
characterised their displacement. Mary Papp remembered her family's circumstances and described her father's decision for the family to begin a new life in New Zealand and his hopes for their future:

Nobody had a bloody clue where New Zealand was. They said 'oh, you know it's a tropical island and it is always warm and you don't even need to take any winter clothes 'cause it's always warm and it's beautiful. Well, my dad looked at it on the map and he said, 'Oh well, you know, it's a long way from Europe which is good'. So he put our name down. ${ }^{13}$

Fellow refugee Steve Fejos also described his family putting the emotional stress and uncertainty of worn-torn Europe behind them.

The Hungarians very much having come with nothing. [...] All the Hungarians are extremely grateful for what was done for them [...]. Very few chose [to come to New Zealand]-you were just happy to be accepted. [After] eleven months in a refugee camp-you were just happy to go anywhere. ${ }^{14}$

All these refugees knew very little about New Zealand, but all were seeking a safe place to live far from the turmoil in their homelands. These excerpts give us insight into not just the horror they left behind them, but their relief in finding a safe place they could begin rebuilding their lives.

All the interviewees had strong memories of their first impressions of Ngaroma. They described their awe of the grandeur of the building, having anticipated something more modest. Stefania Zawada, described her first 1948 impression of Ngaroma:

We arrived by train at the Wellington Railway Station and there we were met by Sister Alexandrowicz who was in charge of the group of the nuns that were running the place. She got us into a taxi. There must have been about five of us but I can remember $[\ldots]$ the moment of arrival at the Polish Girls's Hostel [...]. We came to that main driveway and it was really magnificent - I was impressed — the trees [...] were practically touching at the top [...]. And we drove in and I just couldn't help but (I was a very quiet girl by the way) exclaim 'Oh isn't that beautiful'. And my friend

\footnotetext{
${ }^{13}$ Mary Papp, 6 July 2017.

${ }^{14}$ Steve Fejos, 27 June 2017.
} 
gave me a nudge and said 'Quiet! Quiet!'. And I remember Sister Alexandrowicz turning around and smiling in approval. And you can just imagine $[\ldots]$ on the side there you have the marble staircase, we entered there, that entrance is magnificent, at that time to me it appeared brand new, marble, and huge door [...]. We just took it all in. ${ }^{15}$

Mary Papp also recalled her arrival in Wellington harbour over a decade later in 1959. They disembarked from the ship Sibajak after a long and uncomfortable journey from Europe to the safety of Ngaroma:

The bus took us up to Mt Victoria lookout. Oh my God it was absolutely... [lost for words] - it was magic. It was like you were on the top of the world and it was magic. Then we got back on the bus and they took us to the Polish Hostel. When you go up there and you drive up that drive and this building - when you have come from a one bedroom flat, and you have lived with hundreds of people and you've slept 20 to a room and there was only one toilet and whatever and then the bus stops up here and you think, 'Oh my God what is that, that's from a storybook!' Obviously, the people in there had been told that a new lot of Hungarians were coming, and they all came down. They had been through exactly what we had. And they came down and there were hugs and kisses and tears everywhere-it was just wonderful. ${ }^{16}$

The visual impact of the magnificence of the house and its impression on the young girls is still recalled today. It has become a part of their narration of their life stories, shot through with emotion about the safety and security they found there, and the sense of adventure that their first glimpse that their new home afforded them.

As time passed the various groups at Ngaroma became tight-knit and there was a strong sense of community, particularly amongst the refugees who were resident there. They had shared origins and faced the same challenges adjusting to New Zealand culture.

[The kitchen] was the only place that I ever heard anybody argue - the women in the kitchen, over the stove or over this or over that. Apart from that nobody, nobody argued, everybody was really friendly [...]. Hungarians talked Hungarian, because

\footnotetext{
${ }^{15}$ Stefania Zawada interviewed by Miranda Williamson on 11 May 2017, Alicetown.

${ }^{16}$ Mary Papp, 27 April 2017.
} 
you know nobody could speak English, the Polish spoke Polish and the Yugoslavs spoke Yugoslav and we just intermingled. It was absolutely beautiful. ${ }^{17}$

They shared not only common languages and accommodation, but they also sometimes ate meals together. This all contributed to their sense of solidarity and togetherness, and the adults and older children took pride in self-sufficiency, keeping the house clean and orderly and tending to plots in the garden. The children also had a strong sense of cohesion, recalling communal life and the adventures and high jinks that they enjoyed in the grounds and local area. Maria Campbell recalled muddy childhood mischief, sometimes thwarted by the Ursuline Sisters who cared for her.

Well we [younger girls] weren't allowed to go to the beach, so we used to go out of the boundary, play in the mud and come back. So we wouldn't get told off so we brought [back] some flowers for the chapel—-the white lilies. And the nuns said 'Where did you get the white lilies from?' 'Oh, the creek just down below here'. And they said, 'Oh you've been on the boundary?' I said, 'no they were growing just above the boundary'-so we wouldn't get told off! ${ }^{18}$

The adults also supported each other and there was a collective sense of attachment to the place and a shared determination to make a success of life in New Zealand.

Solidarity existed within Ngaroma, but there were also important links established between Ngaroma's residents and the local Kilbirnie and Lyall Bay communities. To the refugees, learning English was a priority and they were grateful for the conversation practice with locals. Shortly after the arrival of a new group of Hungarians to Ngaroma, a local Catholic priest encouraged his parishioners to visit them.

At the Holy Cross church the priest said, in one of his sermons, that if anybody has any spare time would they go up to the Polish Hostel because there are a whole lot of refugees and they don't speak any English, and you know just to have a chat with them. ${ }^{19}$

\footnotetext{
${ }^{17}$ Mary Papp, 6 July 2017.

${ }^{18}$ Maria Campbell, 14 June 2017.

${ }^{19}$ Mary Papp, 6 July 2017.
} 
English classes were held in the basement area of Ngaroma and the sound of broken English must have pervaded the hostel. Despite the language barrier, there was curiosity on both sides and many lasting friendships were established this way.

Catholicism also united many of the house's varied occupants. From 1947 the central space in the basement was set up as chapel, complete with altar and pews and for many years daily morning mass was a part of life at Ngaroma. Those who attended included the Polish girls and the Ursuline nuns who cared for them, the Sisters of Good Shepherd, the rotating roster of papal nuncio, monsignor and nuns from the Filipino Workers of Christ the Worker order and Catholics from the local Kilbirnie and Lyall Bay community. The nunciature gardener Chris Hampton described 'a real community spirit' amongst mass-goers there. ${ }^{20}$ He recalled:

They used to have mass in the chapel every morning at half past seven and on Saturdays and Sundays it was at eight o'clock. There was always quite a community of local people who would come on a daily basis for mass. It became quite a nice little group of people that you would get to know. ${ }^{21}$

Carmel Fahey, a long-time Kilbirnie resident, also recalled the importance of daily mass to her and her husband's everyday life.

We found out that they had mass there on the weekend [...]. [My late husband] John was an early riser and he always liked to go to mass if he could before he went to work [...]. There was a few of us that went up, and more people came as the time went on $[\ldots]$. There were people from the local community, the nuns from the Home of Compassion often came over, and the nuns from Island Bay [... It was] lovely having the archbishop coming to say mass with us. [...] [The papal nuncios were all] very nice, [although] some of them hard to understand. [The Filipino nuns were also] all very nice $[\ldots]$ They were there doing all the work at the nunciature... housework, all the meals, washing... Mainly three, four if a changeover. [...] We'd go upstairs, fill time in with the nuns and quite often they would cook us breakfast'.22

\footnotetext{
${ }^{20}$ Chris Hampton, 27 April 2017.

${ }^{21}$ Chris Hampton, 27 April 2017.

${ }^{22}$ Carmel Fahey interviewed by Miranda Williamson on 30 June 2017, Kilbirnie.
} 
These connections developed relationships between the local community and those at Ngaroma-friendships and relationships that drew Ngaroma in to become part of the local Kilbirnie and Lyall Bay communities.

The succession of Workers of Christ the Worker Filipino nuns, cooking and cleaning for the nunciature, also became part of the local community. Living in spartan quarters in the separate garage building, they were tasked with cooking and cleaning for the papal nuncio, monsignor and any visitors. Their quiet industry impressed nunciature gardener Chris Hampton, and he recalled teaching several of them to drive around the winding roads in the vicinity:

They would arrive in New Zealand and they couldn't drive, so one of the things I did, I taught about four of the nuns how to drive. So we would go out for driving lessons. We used to go 'round and down to Island Bay and back and all round there. One of the nuns who was getting ready for her licence [drove off the road ... she] rang me bawling her eyes out in a real panic ... [and] a crowd of about six or seven [went up to help]. ${ }^{23}$

In addition to its importance to the local community, Ngaroma has also had a surprising array of international connections. The stories of the Polish and Hungarian refugees link back to events in war-torn Europe. Stefania Sondej, one of the Polish girls who came to Ngaroma via the Pahīatua Camp, recalled their earlier arrival in New Zealand from Iran. She described not just factual information, but a sensory explanation of how she felt about her experience:

Persia $[\ldots]$ is a desert, there are hills and so on but they are mostly covered with sand [...] General picture: Iran desert. Then the ocean, water-water everywhere. Then we saw little islands so green and lovely [...]. Green...Honestly, I just remember green [...]. After Iran, then ocean, then these little green islands...I can feel the thrill now.... ${ }^{24}$

This description is particularly insightful because it describes both the event of arriving, how she felt about it at the time and how it still affects her today. As such, it is a good example of

\footnotetext{
${ }^{23}$ Chris Hampton, 27 April 2017.

${ }^{24}$ Stefania Sondej interviewed by Miranda Williamson on 26 July 2017, Korokoro.
} 
how emotion and the senses can be conveyed through oral history to enhance our understanding of these memories.

The primarily Hungarian refugee groups, who arrived subsequently, were also fleeing wartorn Europe and the chaos and turmoil of the 1956 Hungarian Revolution. Steve Fejos recalled:

Like many of the Hungarians we were of the ' 56 era - we call them the '56ers'. They were the Hungarians that left after the uprising. Most of them had to leave because of either a part involvement in the uprising or just simply a need to move away from the situation that was there. ${ }^{25}$

But as time went on these connections to Europe became less important, particularly for the children. Stefania Sondej recalled that as time passed, 'Poland was something somewhere above the clouds - not quite real' ${ }^{26}$ Although she can still recall the event of her arrival in Wellington harbour in detail, her refugee experience and Polish identity before that had faded.

When acquired by the Holy See in 1947, Ngaroma also established an international connection to the Vatican - the house often described as the Vatican's 'farthest outpost'. They experienced the international spotlight when they hosted Pope John Paul II in November 1986 - a visit of huge importance to New Zealand's Catholic community-Chris Hampton recalling that it 'was a thrill for Lyall Bay, and Wellington and the area' ${ }^{27}$ During her interview Stefania Zawada was astonished and rather pleased to learn that it was her old dormitory bedroom that accommodated the Pope during this visit. Ngaroma, as the apostolic delegate, then papal nunciature, was the base for the Vatican's area of responsibility - around not just New Zealand but throughout the Pacific. Neighbour Jacqui Bisley recalled Archbishop Charles Balvo's frequent travel:

'Cause he had an enormous area too, so he was right over the South Pacific. He would go over to Polynesia and I think Micronesia. He had a very, very large geographical

\footnotetext{
${ }^{25}$ Steve Fejos, 27 June 2017.

${ }^{26}$ Stefania Sondej, 26 July 2017.

${ }^{27}$ Chris Hampton, 27 April 2017.
} 
area to go in and $[\ldots]$ he would dart around the place. And he liked that, he enjoyed travelling in all those different cultures and he made great enjoyment out of it. ${ }^{28}$

The interviews show that Ngaroma's apparent seclusion is misleading - the building has been central to a wide range of international connections that have shaped its history, from Poland to the Vatican, these links criss-cross Europe.

Despite housing successive institutions, Ngaroma was never just a building, it was a homeparticularly for the Polish and Hungarian refugee children and later for the boarding Catholic girls. All describe an emotional attachment to the place. To them Ngaroma had its own rhythms and routines and was a close-knit community. Steve Fejos recalled 'I remember the kitchen was a very large kitchen. It was a very communal environment and we often all ate there as different families we would eat at the same time'. ${ }^{29}$ He also said that 'those Hungarians that are still living, they are like aunts and uncles and sisters to me'. ${ }^{30}$ Maria Campbell also told of 'going in the hall wearing our nighties to say the prayers. And after the prayers we used to go in our dormitory and the girls used to take their mattresses on the ground and do a lot of gymnastics and tell stories'. ${ }^{31}$ The interviews indicate that that the comfort of the spacious rooms and the kindness of those who ran the institutions made the building a real home, though regulated by the routine of bells, rules and mealtimes.

To Steve Fejos' family Ngaroma was part of their family success story of integrating into a new culture and prospering.

[My parents] saw the opportunities here, so they saw that as a wonderful gift and a wonderful opportunity, possibly comparing it to say the other workers that just took that for granted. The Hungarians very much having come with nothing. My parents arrived literally with a suitcase that had half a dozen nappies and a couple of shirts and ultimately the clothes they were wearing. So, they took advantage of this

\footnotetext{
${ }^{28}$ Jacqui Bisley interviewed by Miranda Williamson on 16 August 2017, Lyall Bay.

${ }^{29}$ Steve Fejos, 27 June 2017.

${ }^{30}$ Steve Fejos, 27 June 2017.

${ }^{31}$ Maria Campbell, 14 June 2017.
} 
wonderful gift and opportunity and all the Hungarians are extremely grateful for what was done for them. ${ }^{32}$

He goes on to describe the strong work ethic his parents instilled in him.

What they saw here was opportunities that they just did not have in a Communist Eastern Bloc area. And the one thing my parents taught us - both my brother and myself - that in New Zealand there are a hundred opportunities every single day. Yes, they were harder working, because they had so much more to gain and they saw the opportunities here so they saw that as a wonderful gift and a wonderful opportunity. ${ }^{33}$

With the benefit of maturity and hindsight, the interviewees were all able to step back and consider how their experiences at Ngaroma shaped their character and expectations in life. In our Ngaroma case study, these memories are uniformly positive.

Oral history can also give us unique insight into the personalities and character of the individuals who populate a building's history. Several said that their time at Ngaroma had shaped their character in a positive way-encouraging them to make the most of the opportunities available to them. They had good role models in the people around them-from the entrepreneurship of fellow refugees to the kindness of the various Catholic nuns and the interactions with curious locals. Stefania Zawada talked of her childhood and time at Ngaroma teaching her that 'you have to be adaptable to new situations' ${ }^{34}$ After her interview, her husband Józef Zawada commented that he thought it was this resilience that had made Stefania Zawada a wonderful mother. At Ngaroma, from the Polish Ursuline nuns, to individual refugees and the various archbishops and monsignors - all are described by the interviewees with candour. Their personalities can be understood by descriptions of their character and memories of their conduct. Stefania Sondej and Stefania Zawada both talked of the Polish Ursuline sisters who ran Ngaroma as the Polish Girls' Hostel:

The nuns-I knew them from the [Pahīatua] Camp. The one in charge of the hostel, Sister Alexandrowicz-you don't find women like that anymore. She never shouted at us, for example. She knew all about each one of us. If it was your name day or

\footnotetext{
${ }^{32}$ Steve Fejos, 27 June 2017.

${ }^{33}$ Steve Fejos, 27 June 2017.

34 Stefania Zawada, 11 May 2017.
} 
something she would come up and kiss you on the forehead and give you a hug and so on. She brought us up — she really educated us as far as living was concerned. ${ }^{35}$

Her friend Stefania Zawada remembered that:

[In the central hall was the recreation area and] there was a radio over there and Sister Brennan [...] used to listen to all the news [...] just what is going on in the world-if you came and sat next to her sometimes she would tell you all about it which was rather nice. She was highly knowledgeable and a very nice person. ${ }^{36}$

The warmth of the sisters and the emotional security they provided for the children shines through in these excerpts. Some of the people who are remembered in these stories, like Sister Alexandrowicz and Sister Brennan, have now passed away so this information is now best accessed through the oral histories of the children they cared for.

Other descriptions of personalities emerge from the interviews. Entrepreneurial spirit was alive and well within the mainly Hungarian, but also Yugoslavian and Ukrainian, refugee group that arrived later in the 1950s. Mary Papp admired the resourcefulness of one of the residents and talked of adventures with her father:

He was a very, very clever man $[\ldots]$. He used to go to the Owhiro Bay dump [...]. In those days, the dump was like a treasure chest - although it was stinky — and he would bring things back and he would sell it for peanuts to all the other refugees. Then my dad and I found out where the dump was and my father had an old push bike and we would go, him and me, on this bloody pushbike. And we would have to push it up the hill [...] we would fossick around and all our treasures that him and I found [...] tie on the bike and take it back to the hostel [...]. It was like going into a junk shop-it was lots of fun. ${ }^{37}$

This description conjures up not just the emotions of exploration and adventure, but the 'stinky' smell of the dump that gives a vivid olfactory aspect to the telling of this story.

\footnotetext{
${ }^{35}$ Stefania Sondej, 26 July 2017.

${ }^{36}$ Stefania Zawada, 11 May 2017.

${ }^{37}$ Mary Papp, 6 July 2017.
} 
Interviewee, and nunciature neighbour, Jacqui Bisley talked warmly of her friendship with the American archbishop Charles Balvo, her neighbour and friend, during his time as the archbishop at the papal nuncio at Ngaroma, from 2005 to 2013.

He was a very intelligent, warm, kind of humorous sort of person, really. He could preach a very good sermon. He was an intellectual. His great interest was in history [...]. But he loved children. [...] The archbishop loved living in New Zealand. He really enjoyed the attitude of the New Zealand people and he had a lot of friends-I never heard anyone speak ill of him. He was a very generous man. He loved meeting people. He was interested in people. To him people all had their interesting points. It didn't matter if you were the gardener or a fellow archbishop he would have a really interested conversation with you. He was a great man for hearing about people's lives and thoughts. And he would hold the floor. [...] He used to go swimming down at Lyall Bay, he used to enjoy the sea. He used to be a great walker-you would see him out there striding along every day. ${ }^{38}$

Although all buildings might have an interesting assortment of potential interviewees, Ngaroma proved to have a particularly rich trove because of the unusual diversity of people who have had a connection to it.

Oral history can also bring surprising and sometimes insightful material to light that would not be accessible from any other source. At Ngaroma there are two stories that illustrate unexpected insight. Firstly, Ngaroma still occupies a nostalgic cornerstone of the Gibbons family's history and Paddy Hope Gibbons returned with her godson John Gibbons in the 1990s. He described their visit to her childhood home.

We walked up the main stairwell and Paddy said, 'I wonder if they knew about Dad's secret locker?' [...] She said, 'just a minute' and she tapped on some panels on the wall...on the side of the stairwell [backstairs by the kitchen]. [...] The doors went 'eeerch' and opened up and there was a cupboard and in the cupboard were some bottles of brandy and whiskey all covered in dust and had been there God knows how long. And she said, 'obviously the Pope's representative didn't know this was here'. And he was there and he said, 'how do we get into this?' [...] She had actually just

\footnotetext{
${ }^{38}$ Jacqui Bisley, 16 August 2017.
} 
tapped on the wall. I did ask her 'how did you know about it?' 'Oh' she said, 'Well Dad used to keep his hidden supplies here and wonder why they regularly disappeared because we all knew where it was.' [Laughter]. ${ }^{39}$

A story, that further illustrates insight, is the escape plan of Archbishop Charles Balvo. Ngaroma's current structural integrity is dubious and in response Archbishop Balvo devised his personal earthquake escape plan. Neighbour Jacqui Bisley recalled it with humour:

[The nunciature] had a dreadful earthquake rating after the earthquakes. [...] I always remember the archbishop having his exit plan - if the worst came to the worst, he was going to be out that back door'. ${ }^{40}$

This gives us intriguing insight to the archbishop's concern about the safety of the building and his pragmatic response, which would not have come to light through any methodology other than oral history.

It is evident from all nine interviewees that Ngaroma is remembered fondly. Stefania Sondej talked of Ngaroma as 'the happiest place in my life, for me. Yes, it really was'. ${ }^{41}$ Stefania Zawada also recalled is as 'a great experience. There was security. Quite different [from the] military fashion at the [Pahīatua] camp, then at the hostel everything just became a little bit nicer- the food, the way we ate...' ${ }^{42}$ To Steve Fejos:

Ngaroma represented to the Hungarians a lot of security, it represented a new beginning, and it represented a normal life from where they have come from. So, there is nothing but praise, nothing but fond memories, nothing but great love of the building and the community that lived there through the late fifties and early to midsixties. $^{43}$

Mary Papp concluded that it was 'a privilege to live there'. ${ }^{44}$ The sense of security pervades the interviews, is not always articulated, but always implied. Ngaroma was a safe place and a genuine home which is still remembered and talked about today with nostalgia.

\footnotetext{
${ }^{39}$ John Gibbons, 6 June 2017.

${ }^{40}$ Jacqui Bisley, 16 August 2017.

${ }^{41}$ Stefania Sondej, 26 July 2017.

${ }^{42}$ Stefania Zawada, 11 May 2017.

${ }^{43}$ Steve Fejos, 27 June 2017.

${ }^{44}$ Mary Papp, 6 July 2017.
} 
The senses, particularly descriptions of smell, sight, touch and sound, are woven through these excerpts and are an indelible part of the memories that the interviewees recall. They are particularly important to those remembering their perspectives of childhood-a time when the senses were critical to making sense of the world around them. Through these sensory descriptions our understanding of the house is rounded out and given real vivacity and depth. The senses also identify the contrasts, verbatim and descriptions that make these interviewees real storytellers through recounting an assortment of vivid sensory information-from the white paint spilled on the red carpet; the 'stinky' smell of the dump; the chaotic games of the children playing in the mud to the order and ritual of the Catholic mass. The sensory information that laces through these interviews gives us insight into the dynamics of life at the house. From the childish fear of the darkness of the bush, the warmth of the nuns kissing the children on the forehead on their birthdays, and the memories of security provide insight that might surprise outsiders. They give us another dimension to the case study examining how we can use oral history to learn about and present the stories of built heritage.

\section{Conclusion}

The information gathered through the nine interviews builds on our basic library- and archive-based understanding of the history of Ngaroma which was established in Chapter Two. In this third chapter oral history opens up an understanding of both the social and physical fabric of Ngaroma as established through oral history interviews. Of particular interest are the changing fortunes of the building's fabric and an indication of what the building has meant to different groups of people. This type of information would be difficult to glean in depth from any other source. Memory, emotions and senses, are all central concepts to this thesis that we need to investigate further. The next chapter will discuss the use of oral history to generate information about built heritage and strive to give us a clearer picture of the considerations of undertaking oral history as a methodology in this context, and its implications for heritage management. 


\section{Chapter Four - Discussion}

You see that is why I talk to many. That is why I interview many and have them tell their story. So

from the little that I get from everyone, the mosaic, a total picture can be assembled. Now you understand my purpose. Why I want to collect two-hundred spools of these interviews because nobody can tell the whole story. —David Boder ${ }^{1}$

\section{Introduction}

This thesis considers the potential for the methodology of oral history to improve and extend both academic and professional practice in the heritage field, by exploring how we can use interviews as a methodology to build on material sourced from archives and libraries to understand and tell the stories of built heritage. As Chapter Three showed, oral interviews can tell us about the social fabric and physical fabric of a building, giving us insight into the stories and memories of the people who populated it. This fourth chapter further builds on data from the Ngaroma case study. It weighs the limitations and advantages of using oral history when researching built heritage and considers the part that memory, senses and emotion play in this context. Finally, it introduces the concept of numinous fabric as a practical approach to help scholars and practitioners undertake oral history when they research built heritage.

\section{Limitations: Considerations of oral history in heritage practice}

The limitations to using oral history as a research tool in the built heritage context can be understood through the prism of the Ngaroma case study. In the past, oral history has been criticised as 'a highly problematic strand of data', due to its 'partial, subjective, reflexive, ambiguous, sometimes contradictory and often tensioned' nature. ${ }^{2}$ This thesis acknowledges these shortcomings, but argues that, used thoughtfully, we can find ways to counter, or mitigate, these limitations.

\footnotetext{
${ }^{1}$ Alan Rosen, The Wonder of Their Voices: The 1946 Holocaust Interviews of David Boder (Oxford and New York: Oxford University Press, 2010), 78.

${ }^{2}$ Riley and Harvey, "Landscape Archaeology, Heritage and the Community in Devon," 272.
} 
The greatest, and most obvious, limitation of using oral history is that interviews are only appropriate as a methodology to generate material for a time period which is limited to the lifetime memories of an interviewee. (However, this thesis takes the approach of including stories that may have been passed down to them-more often called 'oral tradition', evident in the John Gibbons interview). This gives oral history a very specific application within heritage studies. To overcome this limitation, we can use oral history in conjunction with other methods as we seek to tell the wider stories of built heritage. As Trower writes, 'places are not fixed, static, preservable entities' with only one recent story to tell. ${ }^{3}$ It is practical to use oral history to mine information about the recent epochs of a building's history, but still consult other sources for information that inform us about earlier periods of a structure's history.

When an oral history approach is considered by heritage practitioners outside of academia, its practicality is often questioned. From the heritage practitioners who shared their perspectives and experiences in Chapter One, we can understand some of the reasons why practitioners choose not to undertake oral history. As Elizabeth Cox notes, oral interviews are 'very time consuming to collect, and very time consuming to use' and often clients are reluctant to spend money on something they may see as unnecessary. ${ }^{4}$ Under pressure to rapidly produce conservation plans, reports or heritage inventories, it is understandable, although disappointing, that practitioners may stop short of using oral history and choose to use sources of information closer to hand from archives and libraries, an approach which they perceived to be more streamlined. However, this thesis seeks to champion using oral history when researching built heritage and in doing so challenges these practitioners to extend their research process.

Limitations are evident in the practicalities of using the snowball sampling method in the built heritage context. Establishing contacts and potential interviewees by tapping into one group can lead to a limitation in the diversity of perspective. This can happen when family members, friends, neighbours or others who lived in a building at the same time provide each other's contact details as suggestions for future interviewees. Despite the best of intentions, in

\footnotetext{
3 Trower, "Introduction," 13.

${ }^{4}$ Elizabeth Cox, Heritage Consultant, email to author, 14 August 2017.
} 
doing so they inadvertently limit the sample pool to their immediate cohort. In the Ngaroma case study, sisters-in-law Stefania Zawada and Stefania Sondej were both interviewed, and provided stories that interlinked in perspective. But it was helpful when others, like Kilbirnie resident and regular mass-goer Carmel Fahey, provided diversity to the pool of interviewees. Different perspectives provided a richer mix of data and explicated a wider understanding of other epochs of the building's history. Both heritage professionals and heritage studies academics need to be aware of this potential pitfall when they are using this method of sampling to identify potential interviewees.

In the past the reliability and validity of material accrued through interviews have been questioned. Often material gleaned from interviews does not line up perfectly with other interviews or different sources and is impossible to verify elsewhere. Abrams writes that academics have criticised the use of oral history, arguing that oral history 'did not produce data which could be verified or counted' and was thus an unreliable method. ${ }^{5}$ This is mainly because oral history 'rested upon memory' and memory was regarded as 'unreliable'. ${ }^{6}$ In this case study conflicting information has been evident, as interviewees disagreed over room usage and allocation, key dates were contested, an entire kitchen appeared and disappeared from the upper level and the names of people forgotten. It is helpful to be able to confirm key information from more than one source for peace of mind, but it is the nature of oral history that a significant bulk of material will be impossible to verify elsewhere, but scholars like Portelli and Passerini argue that that doesn't make the information any less valuable.

'Unverifiable' material evident in the interviews extended to dates-in general the interviewees didn't remember dates or the specifics of changes or modifications made to Ngaroma. They preferred to talk about the social fabric of a building - to recount stories, describe personalities and reminisce about the escapades of a bygone era. When pressed, some hazarded guesses about the dates of changes to the physical fabric or modifications to the building. Others chose not to. In this case study this limitation was mitigated by the consultation of plans and maps from the Wellington City Council Archives, which provided information about dates and structural changes that was missing from material provided by

\footnotetext{
${ }^{5}$ Abrams, Oral History Theory, 5.

${ }^{6}$ Abrams, 5.
} 
the interviewees. In this way I balanced the material with other sources to build up a picture from multiple sources and, in doing so, sought to overcome this limitation.

Another common criticism of oral history is that it is too subjective. The interviewer brings their subjectivity to the process, and so does the interviewee. Recent oral history literature across the disciplines now advocates for a better understanding of subjectivity and how, in our response, we can strive to be reflexive in the interview and writing process. Today, acknowledging one's own motivations, experience and impact on the interview process has become both 'inescapable and crucial'. ${ }^{7}$ The background, interests and personalities of my interviewees inevitably coloured their perspectives. Interviewee Jacqui Bisley variously described herself as a friend, neighbour, part of the Lyall Bay community, periodic mass-goer at the nunciature, and Anglican. ${ }^{8}$ These labels interlink, ebbing and flowing through her interview describing her relationship as a neighbour to the community at Ngaroma. Again, this 'limitation' has been famously reworked by Passerini and Portelli as an advantage, as we will see in the next section.

\section{Advantages: What oral history can bring to heritage practice}

There are a number of advantages to using oral history as a tool when researching built heritage. It can provide a window allowing us access to unique material, and as Yow comments, oral interviews can 'offer answers to questions that no other methodology can provide'. ${ }^{9}$ Sørensen advises us that through oral history we can learn about 'complex and abstract relations, thoughts and feelings' ${ }^{10}$ At Ngaroma, the interviews had a number of advantages, clearly able to offer what Riley and Harvey describe as 'a more nuanced, dynamic and rich account' than archive or library-based research would provide. ${ }^{11}$

\footnotetext{
${ }^{7}$ Yow, Recording Oral History, 26.

${ }^{8}$ Jacqui Bisley, 16 August 2017.

${ }^{9}$ Yow, Recording Oral History, 9.

${ }^{10}$ Sørensen, "Between the Lines and in the Margins: Interviewing People about Attitudes to Heritage and Identity," 164.

${ }^{11}$ Riley and Harvey, "Landscape Archaeology, Heritage and the Community in Devon," 270.
} 
The data generated by interviews can unearth material that breathes 'color and life' into the stories we are trying to tell about built heritage, infusing a structure's history with vivacity and insight that would be impossible to find from any other source, and in doing so, livens up the presentation of the material. ${ }^{12}$ At Ngaroma, Stefania Zawada recounted the ghost stories the children told of the 'Black Lady' who traversed the halls of Ngaroma during the middle of the night—-just to make life more interesting'—which adds interest to our understanding of life there. ${ }^{13}$

As I established in the literature review, it is the very subjectivity of oral interviews that make them a rich source of material. They can tell us not just what people did, but what they thought about it. Subjectivity allows us to 'reveal the meanings of lived experience' and its attendant variety of perspective and opinion. ${ }^{14}$ The Ngaroma interviewees had definite opinions about politics and personalities and brought their own diverse perspectives to not just remembering the building but talking about their memories of daily life at Ngaroma and the people who had populated it. They sometimes disagreed, and at other times concurred, but all seemed to relish the opportunity to reminisce about a bygone era.

Oral history has been criticised for mining information that is incorrect and impossible to verify elsewhere. But today scholarship acknowledges that this information is still valuable as it can tell us about 'underlying meaning', and in doing so becomes a unique advantage of the approach. ${ }^{15}$ As Portelli notes, 'the importance of oral testimony may lie not in its adherence to fact, but rather in its departure from it'. ${ }^{16}$ At Ngaroma, the basement chapel was described by Chris Hampton as a 'cosy' focal point for the area's Catholic community, replete with 'community spirit'. ${ }^{17}$ In reality, the room is dark and gloomy, with crumbling brick walls and a pervading sense of cold and damp. Perhaps what he was remembering was the warmth, friendliness and sense of community with the other mass-goers, the clergy and the nuns. $\mathrm{He}$ was remembering the experience of attending mass there, what it felt like, rather than the state of the physical fabric of the room. But this information is still valuable as it tells us

\footnotetext{
${ }^{12}$ Hamilton and Shopes, "Introduction: Building Partnerships Between Oral History and Memory Studies," xii.

${ }^{13}$ Stefania Sondej, 26 July 2017.

${ }^{14}$ Yow, Recording Oral History, 26.

${ }^{15}$ Marcus, "Oral History and the Documentation of Historic Sites: Recording Sense of Place," 3.

${ }^{16}$ Portelli, The Death of Luigi Trastulli, and Other Stories, 51.

${ }^{17}$ Chris Hampton, 27 April 2017.
} 
about his perspective and memories of Ngaroma - a description of what the experience meant to him.

The literature has begun to recognise the place that orality plays in the interview process, and its, often overlooked, unique contribution to the data. Both Portelli and Passerini explore this quality, considering not only what is said but how it is said, what is and what isn't there. Green suggests that this careful listening can lead to a more 'nuanced' understanding of the past. ${ }^{18}$ She writes that the adept oral historian is 'keenly attuned to the many layers of meaning, because they not only read the words but also hear the voices' ${ }^{19}$ This orality includes 'poetic style and vernacular forms of speech'. ${ }^{20}$ Trower notes the richness of the 'different volumes, rhythms, intonations, and inflections' of the voice. ${ }^{21}$ Orality was particularly significant in the interview with Stefania Sondej. Her thick Polish accent, little tempered by her transition to life in New Zealand, lent a shade of authenticity and colour that brought a special quality to our interview.

Oral history can help us understand not only what happened, but how people felt about it, looking at not just what happened, but how it was 'understood and experienced' by the interviewee. ${ }^{22}$ In this way oral history can offer 'emotional content' missing from material generated by other research methodologies. ${ }^{23}$ In the Ngaroma case study from library and archive sources we can see the numbers and statistics of the arriving Hungarians, but it is by talking to the former refugees that we can understand what the decision to emigrate to New Zealand meant to them. Mary Papp remembered the confusion of her father, forced to decide if he would consider New Zealand as a permanent home for his young family. She recalled: 'Nobody had a bloody clue where New Zealand was. [...] Well, my dad looked at it on the map and he said "Well, you know, it's a long way from Europe, which is good". So he put our name down'. ${ }^{24}$ Oral history extends our comprehension of this turning point for the Papp

\footnotetext{
${ }^{18}$ Green, “'Unpacking' the Stories,” 12.

${ }^{19}$ Green, 11.

${ }^{20}$ Riley and Harvey, "Landscape Archaeology, Heritage and the Community in Devon," 282.

${ }^{21}$ Trower, "Introduction," 7.

${ }^{22}$ Green, “"Unpacking' the Stories,” 12.

${ }^{23}$ Abrams, Oral History Theory, 81.

${ }^{24}$ Mary Papp, 6 July 2017.
} 
family, more widely reflecting the Hungarian refugee experience, beyond the dry statistics of the historical record.

It is a significant strength of the method that oral history can allow researchers to include interviewees from disadvantaged, minority or disempowered groups, who may not otherwise make it into any more traditional, written historical record. ${ }^{25}$ Including these groups can provide what is known in heritage studies as a 'bottom up' perspective of history. The Ngaroma case study illustrates this idea as it includes the stories representing several minority groups - including the Polish children, Hungarian refugees and the local Catholic community. However, the concept is best represented by Maria Campbell. She had learning difficulties and a life-long struggle with illiteracy as she missed out on a lot of schooling due to the upheavals of her childhood and long stays in hospital because of polio. Despite her limitations with reading and writing, through oral history she could participate in the project and contribute her own memories with the same validity and level of input as the other interviewees. This is a real strength of the oral history approach.

Oral history can also provide a more reasoned interpretation of the historical record that helps us understand daily life in a building. Yow describes this as 'the very stuff that rarely makes it into any kind of public record'. ${ }^{26}$ It provides an understanding of 'the dimensions of life within a community'. ${ }^{27}$ Green writes that oral history can provide us with 'a more balanced record of the past'. ${ }^{28}$ While stories like Pope John Paul II's visit to Ngaroma appear in the historical record in numerous places, the stories of the Filipino nuns cooking breakfast for the early morning mass-goers from the local community don't. When nunciature gardener Chris Hampton recounted this simple morning ritual he allowed us a glimpse of the daily life 'downstairs' at Ngaroma - a sense of the daily rhythms and routine of the house not recorded elsewhere.

\footnotetext{
${ }^{25}$ Yow, Recording Oral History, xi.

${ }^{26}$ Yow, 12.

27 Yow, 13.

${ }^{28}$ Green, “'Unpacking' the Stories,” 12.
} 
Another unique strength of using oral history to tell the stories of buildings is that it allows for a multiplicity of narratives. This confluence of interviewees' perspectives, taken together, give us a fuller understanding of the history of a structure. There is no one correct version, but by interviewing a range of interviewees we can build up a picture of a place which means 'different things to different people'. ${ }^{29}$ At Ngaroma this is particularly true, as the house was occupied by different groups at different times for different purposes. By focusing on identifying potential interviewees from different periods I attempted to find people who were able to contribute their stories from different epochs of the history of Ngaroma. Considered individually, the interviews gave me useful information, but taken together as an interlinking set, with some overlap, they gave depth to my understanding of the house and its history. I found it surprising that many of the interviewees were disinterested in hearing about other periods of the house's history, preferring to talk about Ngaroma during the time of their particular connection to the building and what it meant to them.

Oral history can help us understand the background and feeling of a locality. This is material about the landscape that 'documents themselves, however closely pressed, fail to yield'. ${ }^{30}$ Riley and Harvey argue that interviews 'help us co-construct the landscape through people's contextualised recollection of that particular place', something they call 'linguistically appropriating the landscape'. ${ }^{31}$ Some of the most interesting material about Ngaroma would not be generated by any other method. In this case study the building's links with the local Lyall Bay community are explicated in various directions through the discursive nature of the interviews. The connections with the priest at the local Catholic Church who encouraged his flock to visit the refugees for English language practice, the Vatican's Archbishop Balvo swimming at the Lyall Bay beach, the stories of the Filipino nuns learning to drive on the winding roads around the vicinity, the huge trees surrounding the property brought down in foul weather; these stories all contribute to build up a visual picture of the local area and those who populated it that is entirely missing from library and archival sources.

\footnotetext{
${ }^{29}$ Riley and Harvey, "Landscape Archaeology, Heritage and the Community in Devon," 276.

${ }^{30}$ Samuel, "Local History and Oral History," 200.

${ }^{31}$ Riley and Harvey, "Landscape Archaeology, Heritage and the Community in Devon," 273.
} 
Another advantage of using oral history as a methodology in heritage studies is that it can situate the story of a structure within the context of New Zealand's wider national history. This provides material that seeks 'to link remembered individual experience with the broader economic and political currents of history'. ${ }^{32}$ This was evident in the narrative of Ngaroma which encompasses the story of the Hope Gibbons family's successful strive for economic prosperity built around a burgeoning Ford car dealership, the stories of refugees fleeing political events half a world away in war-torn Europe, the impact of tough economic times, and the diplomatic relationship with the Vatican culminating in Pope John Paul II's visit to Ngaroma during his 1986 Pacific pilgrimage. Described through oral history, knitting the history of the house into a wider story, our comprehension of Ngaroma is informed by these wider historical events and developments.

The data generated by the interviews also confirm Yow's assertion that oral interviews have the advantage of illustrating 'values embedded in the culture'. ${ }^{33}$ This is evident within the refugee stories of the community at Ngaroma. Steve Fejos describes a widespread hardworking ethic within these groups, using the example of the Hungarian women sewing together pre-cut trousers and the example of the work ethic within his own family. Steve recalled that 'on a really busy week, mum would sew up to a hundred men's trousers', earning money to supplement the family income. ${ }^{34} \mathrm{He}$ talks of these values being part of his family's identity and attitude to work, influencing him even today in his occupation as a real estate agent in the Wellington area.

Another advantage of encouraging heritage professionals and academics to undertake oral history is that as oral collections in libraries around New Zealand are built up, we have repositories of material that can be accessed across the disciplines for consultation by other researchers, who may be exploring other themes or ideas. In this case study, these nine recordings, to be offered to the National Library's oral history collection, may be of use to heritage professionals or other scholars or enthusiasts writing about a wide assortment of topics. Topics not only about Ngaroma, but perhaps the history of the Catholic Church, the

\footnotetext{
${ }^{32}$ Anna Green, "Oral History and History," in Remembering: Writing Oral History, eds. Anna Green and Megan Hutching, (Auckland: Auckland University Press, 2004), 3.

${ }^{33}$ Yow, Recording Oral History, 15.

${ }^{34}$ Steve Fejos, 27 June 2017.
} 
Elizabethan architectural style, the experiences of refugees in New Zealand or Lyall Bay's local history. As these repositories are built up over time and more utilised by researchers, these collections could become a more routinely consulted source of information with intersecting projects and shared data.

In addition to this, oral history can also have a role to play in educating the public. Trower notes that it has the power to 'change perceptions and understandings of places' and the people associated with it. ${ }^{35}$ Steven High, writing from the perspective of survival and displacement, argues that oral history has 'a pivotal role to play' in educating the wider community about minority ethnic or cultural groups. ${ }^{36}$ In the Ngaroma case study, understanding the history of the refugees who fled Europe to make a new life here in New Zealand, can foster greater respect for, and appreciation of, the Hungarian and Polish communities which are still a vibrant part of Wellington today and even the wider contribution of all refugees to New Zealand culture and society.

\section{Memory, senses and emotion}

Memory is central to oral history. As Abrams writes, 'memory, with all its imperfections, mutability and transience is at the heart of our practice and analysis' ${ }^{37}$ There already exists an expansive body of literature around memory studies, but it is not the primary focus of this thesis. However, the Ngaroma case study interviewees can be described as what Benton and Cecil call a 'memory group', this is 'a group of people who have shared some experience', in this case a connection to Ngaroma. ${ }^{38}$ Using oral history to understand a variety of perspectives of Ngaroma confirms that, as Benton and Cecil argue, 'the evocation of the past is de-centred: many voices are encouraged to contribute, rather than the single authoritative voice of the architectural historian. No one meaning is attributed to the buildings'. ${ }^{39}$ By drawing from the memories of a wide range of interviewees, we can build up the history of a

\footnotetext{
35 Trower, "Introduction," 2.

${ }^{36}$ Steven High, Oral History at the Crossroads: Sharing Life Stories of Survival and Displacement (Vancouver: UBC Press, 2014), 7.

${ }^{37}$ Abrams, Oral History Theory, 23.

${ }^{38}$ Benton and Cecil, "Heritage and Public Memory," 13.

${ }^{39}$ Benton and Cecil, 40.
} 
heritage structure that gives us important information about both the social and physical fabric of a building, but we need to be aware that it is subject to the vagaries of memory.

Some of the oral history interviews undertaken here showed up interesting contrasts in information between memory and written sources. In one instance, the papal nunciature's spokesman told a local news reporter writing for the Eastern Suburb News, in an article entitled 'Lyall Bay Papal retreat during whirlwind tour', that no special preparations were undertaken for Pope John Paul II's visit. ${ }^{40}$ This is a striking contrast to the memories of the gardener, Chris Hampton, who tells us that renovations were carried out and the interior was repainted. This gives us different perspectives on the history of the house, from both inside the community and how they wished to present themselves to outsiders.

It was evident that memory also impacted upon the perspective of the interviewees. At the beginning of each interview, it proved important to identify the point in their lives the interviewees were recalling. This consideration was particularly evident in the interviews with the Polish interviewees who had been children at the time. Those who had been older at the time they lived at Ngaroma, like Stefania Sondej, talked of responsibilities, jobs in the workplace and caring for the younger children. In contrast, Maria Campbell, who had been one of the youngest of the girls, talked of games and imposing figures of authority, recalling the nuns as figures of authority intent on ruining her opportunities for fun and adventures in the mud. Stefania Zawada and Stefania Sondej had a more mature perspective and described the nuns as very hardworking in their efforts to make a real home for the children at Ngaroma.

The senses, descriptions of which are woven through the interviews, emerged as part of the valuable and unique contribution that oral history can give to our understanding of built heritage. Joy Damousi and Paula Hamilton challenge us to 'examine afresh a partly known past' through the 'different lens' of the senses. ${ }^{41}$ In this case study sensory descriptions weave through the interviews and spark our imagination. At Ngaroma there are memories of

\footnotetext{
40 "Lyall Bay Papal Retreat during Whirlwind Tour."

${ }^{41}$ Joy Damousi and Paula Hamilton, eds., A Cultural History of Sound, Memory and the Senses (New York and Oxon: Routledge, 2017), 1.
} 
colour, smells, sounds, tastes and touch; the sound of the bells that called the girls to mealtimes, the scent incense in the thurible used in the Catholic mass officiated by the papal nuncio in the chapel, the squelch of children playing in the mud in the creek, the sound of Hungarians practising English phrases in the schoolroom, Sister Brennan listening to the news of the world on the recreation room wireless, the hum of sewing machines as the girls ran up dresses for an upcoming dance, the giggles as children played at boiling each other alive in the whale blubber pot in the garden, the smell of treasures reclaimed during bicycle expeditions to the Owhiro Bay dump, the sound of popular music playing on the gramophone pervading the house on weekends, the coldness of the basement dormitory known as 'the dungeon', the warmth and ritual of the nuns kissing the children on the forehead on birthdays and the darkness and mystery of the bush that encircled the property. These are sensory memories that are brought to light by oral history which in turn give us insight into not just life at Ngaroma but 'the mood of another era'. ${ }^{42}$

Emotion emerged as another valuable aspect of what oral histories can contribute to our understanding of the stories of built heritage. It weaves through the case study interviews, echoing literature on the topic, adding a richness to the Ngaroma data. Despite recalling events decades past, the stories that the interviewees told me were central to their own personal narrative; these were stories about where they came from and the events and places that shaped who they had become. Stefania Sondej recalled the story of her arrival in New Zealand as a Polish refugee child: 'Honestly I just remember green ... After Iran, then ocean, then these little green [islands] ... I can feel the thrill now..... ${ }^{43}$ The interviewees talked of people who had played a significant role in their lives, who had since disappeared from their lives or passed away. Several of the Polish interviewees recalled with sadness having to farewell the Polish Ursuline nuns who had cared for them for more than a decade, when the sisters were required by their order to return permanently to Poland in 1958. Emotion is integral to these interviews and oral history is well-placed to capture it.

\footnotetext{
${ }^{42}$ Hamilton, "Oral History and the Senses," 104.

${ }^{43}$ Stefania Sondej, 26 July 2017.
} 
This same emotion can also be evident in the absence of words. Sørensen describes this as 'a glimpse of something so special that normal use of language could not express it'. ${ }^{44}$ The usually opinionated and unsentimental Mary Papp struggled to find the words to describe her emotions and the view from Mt Victoria after she first disembarked in Wellington from the ship Sibajak in 1959. Her recorded interview does reflect this, and it was noted in the field notes, but this emotion was largely lost from the record during the process of transcription. This indicates that it is still important to retain the original audio recording, rather than abandoning it entirely in favour of a fully transcribed interview.

Emotion is also linked to humour, which has its own implications within the interview. Although there is little literature on the topic, oral historian Ned R. Norrick explores this. He suggests that humour 'reflects the narrator's self-image and attitudes towards the past' and is also a way of mitigating nostalgia. ${ }^{45}$ A quirky sense of humour is evident in Stefania Sondej's interview. She remembered living at Ngaroma as the happiest time in her life and she cheerfully remarked that the Polish girls were well-cared for at the hostel—commenting that 'none of us landed in psychiatric hospital [giggles]. We were really happy at the hostel' ${ }^{46}$

\section{Numinous Fabric in Heritage Studies: A new approach for oral interviews}

This thesis brings 'numinous objects', as a concept from public history and museum collection policy, into the heritage studies context, building on Maines and Glynn's article in The Public Historian. ${ }^{47}$ As explored in the literature review, fabric (or 'objects'), can be used to link extant fabric with its attendant stories. This develops ideas from Schrader who conceptualised his understanding of the fabric of a building to be either physical or social. ${ }^{48} \mathrm{I}$ build on his binary model and identify an overlap between these ideas. I call this overlap 'numinous fabric' and suggest we use it to extend our understanding of how best to undertake oral history interviews when researching the history of built heritage.

\footnotetext{
${ }^{44}$ Sørensen, "Between the Lines and in the Margins: Interviewing People about Attitudes to Heritage and Identity," 173.

${ }^{45}$ Ned R. Norrick, "Humour in Oral History Interviews," Oral History: The Journal of the Oral History Society 34, no. 2 (2006): 86.

${ }^{46}$ Stefania Sondej, 26 July 2017.

${ }^{47}$ Maines and Glynn, "Numinous Objects," 10.

${ }^{48}$ Schrader, We Call It Home, 11.
} 


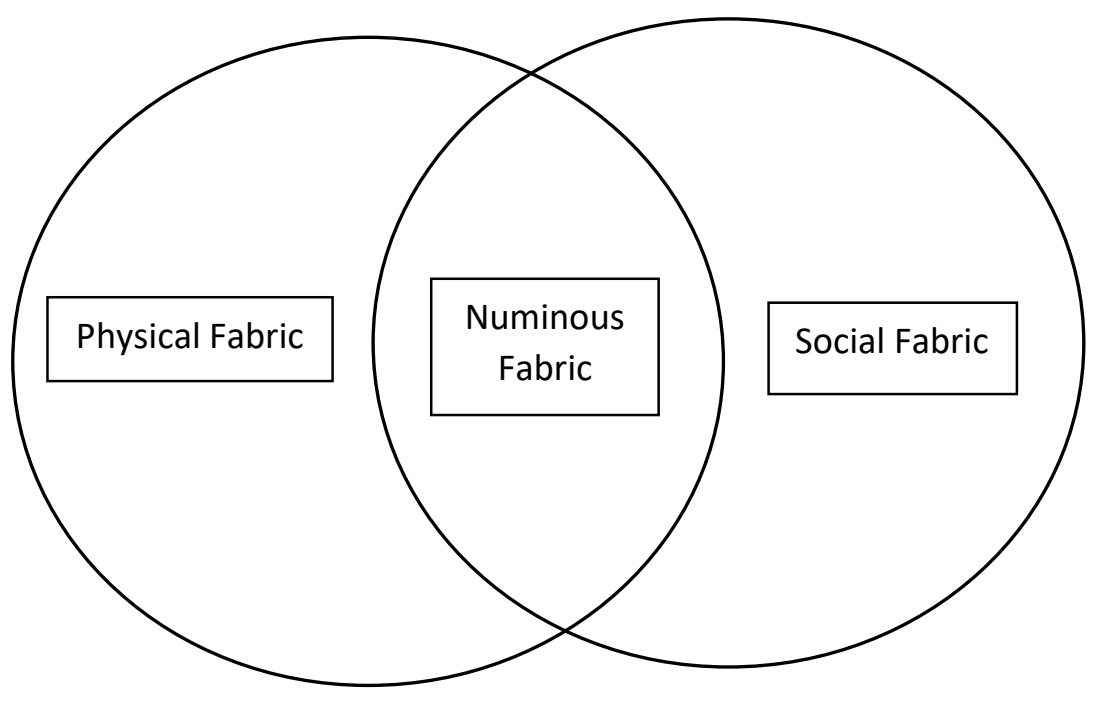

Figure 47: Proposed approach for interviews in heritage studies, identifying 'numinous fabric'-using the overlap between physical fabric and social fabric to guide oral interviews.

I think that this is an exciting new idea which has the potential to challenge us to think more inventively and thoughtfully about what constitutes the physical fabric of a built structure and how it might connect to social fabric and the overlap between. Oral history is uniquely placed as a tool to enable this more sophisticated understanding of a building and all its constituent parts. The phenomenological aspect of this approach is in keeping with the argument and approach of this thesis, engaging with the senses, memories and emotions of the interviewee. Numinous fabric has the power to open up the stories of built heritage and be employed as a practical approach to enable heritage practitioners and academics to undertake oral history in heritage studies. Heritage professionals are well advised to consider what extant objects or fabric in the building's interior, exterior or grounds may provoke or encourage stories that the interviewee may share. A sensitivity to identify and consider what might open up a discussion of value to the project, could increase the sense of value of objects still there today by linking numinous fabric with its attendant stories.

A site visit is key to this approach, so that interesting fabric can be identified and photographed. At Ngaroma some examples of potentially pertinent physical fabric were the staircase with its hidden cupboard, the handsome timber dumb waiter, the beautiful mosaic 
floor at the entrance way, the ornate porte-cochère and the conservatory. We can also consider fabric in the grounds - the water tower, garage and the whale blubber pot.

An example of this approach was evident in the interview with Chris Hampton. He identified the carpet as having a special story attached to it. In the interview he recalled the white paint accidentally spilt on the red carpet prior to Pope John Paul II's arrival at the nunciature. ${ }^{49}$ The carpet is a physical fabric, the memory of the spilling of the paint and the resulting uproar is social fabric. But it can also be conceptualised as numinous fabric as it can sit within the overlap between. The carpet still exists as an object within the house, and people like Chris Hampton still recount the incident with nostalgia and humour. Oral history is well placed to spark and capture these stories and preserve them for posterity.

Further to this, numinous fabric in the Ngaroma case study included artefacts, extant building plans and photographs. As Sørensen writes, artefacts 'are not just any objects but objects that have stories and in particular distinct memories attached to them' and suggests that the touching of an object can be part of the act of recalling memories ${ }^{50}$ For an example of this use of artefacts we can return to Mary Papp's little blue box, the story of which featured in the introduction. It was a real family treasure that inspired her to talk, not just what the object meant to her, but it also led to further discussion about all the other things the family were forced to leave behind when they fled Hungary. The artefact had become a numinous object and a symbol of a particular period of the Papp family story.

Building plans are also a kind of fabric, prompting discussion about the various usage of rooms at Ngaroma. Sourced from the Wellington City Council Archives, Dawson's original 1926 plans show us the dimension of the rooms and their original uses by the Hope Gibbons family, including rooms designated as the main hall, pantry, drawing room, library, sitting room and conservatory. ${ }^{51}$ This gives us a real sense of the spaces in the house and how they worked together. Although room usage changed markedly as successive groups reorganised and reallocated the rooms for different purposes, with these blueprints in front of them the

\footnotetext{
${ }^{49}$ Chris Hampton, 27 April 2017.

${ }^{50}$ Sørensen, "Between the Lines and in the Margins," 174.

${ }^{51}$ Wellington City Archives, [00056:9:B887]
} 
interviewees talked with greater confidence and authority. They felt confident about the information they were providing, and the plans seemed to add legitimacy to the interviews as part of a 'proper history' project.

Photos are also useful to trigger stories and provide another dimension to the interview material. Oral historians call this development the 'photographic turn' ${ }^{52}$ The literature generally acknowledges the usefulness of photographs to the oral history toolbox and Abrams sums up general opinion when she writes that photos are useful because they have the power to 'unlock a series of memory stories'. ${ }^{53}$ Alexander Freund and Alistair Thomson describe the relationship and similarities between photographs and oral history-that they 'intersect at important epistemic points: evidence, memory, and storytelling' and that 'both are used as forms of evidence; both require 'memory work'; and both are forms of storytelling'. ${ }^{54} \mathrm{My}$ data confirms this. After the conclusion of my interview with Stefania Zawada, she and her husband Józef Zawada produced several boxes of black and white Brownie box photos and Stefania Zawada described the stories behind these images with nostalgia and an unusually exacting mind for names and dates. There were images of the girls in traditional Polish dress posing with a Catholic religious icon and other informal snapshots of Stefania Zawada and her friends. These photographs contributed to my understanding of the cultural identity of the children and the importance of the Catholic faith to their community. The informality of some of the 'snaps' echoes the way oral history can capture for posterity insight into aspects of daily life in a place.

This thesis does not seek to supersede archival- and library-based research in heritage practice with oral interviews. The former are still essential parts of the research process to establish a basic history of a building before any oral history interviews are instigated. A thorough understanding of a structure's basic history enables the interviewer to know what questions to ask, what the interviewees potential strengths are, and where the interview might fill gaps in the history. More than anything, this background knowledge gives the interviewer the ability to steer the interview in a useful direction. There is still a place for the traditional

\footnotetext{
52 Abrams, Oral History Theory, x.

53 Abrams, 84.

${ }^{54}$ Alexander Freund and Alistair Thomson, "Introduction: Oral History and Photography," in Oral History and Photography, ed. Alexander Freund and Alistair Thomson (New York: Palgrave Macmillan, 2012), 2.
} 
way heritage professionals have undertaken history by 'checking other sources and comparing accounts'. ${ }^{55}$ But the richness of material generated by oral history can only give depth to our understanding of built heritage and how we choose to research and tell its stories.

\section{Conclusion}

Undertaking interviews with people who have some association with a heritage structure can allow us to tap into a rich resource of material that provides depth and dimension in our understanding of it. There are both limitations and advantages to using oral history as a methodological tool. Memory, senses and emotion are important considerations of oral history in relation to built heritage. This thesis argues that heritage practitioners and academics can focus on numinous fabric to bring together physical fabric with its attendant stories before they slip from memory and record. In the future, the approach to heritage studies and practice should still include archival and library research as a foundation, but also incorporate oral history to help us understand the buildings around us. In the next section I consider the implications of this for heritage management and heritage studies.

${ }^{55}$ Yow, Recording Oral History, 23. 


\section{Conclusion}

This thesis has asked if heritage practitioners and academics working in the heritage field should use oral history as a methodology when researching the stories of built heritage structures. In particular, it has sought to fill the gap in material that is problematic for research that spans the period from the end of the Second World War to today. I have utilised a case study, Ngaroma, to examine how we can use oral history and how we can bring ideas and theory from oral history into heritage studies. I have found that it can be a tool that enables us to extend established methodologies in the field and lead to a richer understanding of built heritage.

This research employed a multi-method, inductive, qualitative approach. The methods used in this research were library-based research, archive-based research and oral history. These methods generated data that included newspaper articles, books, pamphlets, photos, artefacts, conversations and stories which, taken together, have provided a case study that has enabled me to consider the strengths, weaknesses and special considerations of using oral history when researching built heritage in heritage studies.

Oral history is a well-established methodology which has been employed across a range of disciplines. This thesis has sought to bring the methodology into the field of heritage studies. To do this I have engaged with a range of ideas from oral history theory, which were explored most helpfully by scholarship from oral history academics Abrams and Yow. I have looked at the relationship between interviewer and interviewee, noted what interview aids can offer as tools when undertaking oral interviews, weighed the advantages and limitations of using oral history in this context, and engaged with a consideration of memory, senses and emotion. I finish by assessing the potential for a reconsideration of the fabric of a building. To do this I build on Schrader's work, by extending his theories about looking at a building's physical and social fabric. I argue that numinous fabric can guide our interviews to establish stories and anecdotes from the past that link memories with extant fabric and, in doing so, inspire and guide the interview process. In doing this, I make an original contribution to the heritage studies field. 
The building I chose as a case study was Ngaroma. It was built in 1926 by the Hope Gibbons family and has since housed an assortment of groups. I first undertook the established way of researching built heritage by investigation at libraries and archives in Wellington, and so established the basic history of the building. I then went one step further to undertake nine interviews with people who had some connection to the building. These people were identified through snowball sampling. The material I unearthed gave my understanding of the building a depth and richness that would be impossible to find from any other approach. I found out not just about the fabric of the building, but also how people felt about it and what it meant to them. Through this case study I have established that oral history does have the potential to reshape both theory and practice in this field.

There were limitations to this thesis. I carried out nine interviews, but further interviews would have given additional depth to the thesis. It might not always be necessary or even an option, but in this case study it was important to get a wide spread or representative sample of interviewees associated with different epochs of a building's history to build up a picture of its history over time. Unfortunately for this project, the Vatican's representatives were unwilling to be interviewed and this left a gap in the history of the house that I was unable to fill. Because Ngaroma is constructed in an architectural style rare in New Zealand, has palatial proportions and has an unusual history housing a variety of different groups, it isn't representative of most built heritage in New Zealand. A more pedestrian building, like a state house or a commercial shop, may have made for a more representative case study. However, the process of snowball sampling, conducting interviews and analysing the data would be the same and the process described in this thesis is applicable for the research process for any heritage structure.

Work can be undertaken to further address the considerations of bringing oral history into heritage studies and its impact on both the theory and practice in this field. Further research could investigate applying oral history interviews to a wider range of structures, to establish if interviews are equally effective when applied to other kinds of built heritage, like sea walls, lighthouses or bridges. Research could also investigate other ways of finding interviewees apart from snowball sampling. Work could also look at different age groups and how their perspectives impact on their memories of a place. 
This thesis hopes to make an impact on professional practice. If we can persuade heritage practitioners and academics to use oral history as a methodological tool, heritage management practice and academic scholarship will be developed and extended. By interviewing people with a connection to the built heritage under investigation, they can tap into a rich trove of material that leads to a fuller understanding of the social, physical and numinous fabric of built heritage. Oral history is well placed to help us 'catch' numinous fabric stories before they fade from memory and the historical record. I make a number of recommendations for how we can do this. They are as follows:

- In New Zealand oral history training should be a part of the course for heritage students who undertake postgraduate study at places like Victoria University of Wellington and Massey University. Giving these students practical skills, an understanding of the underpinning theory and the confidence to undertake oral history and then take these skills into the workforce would lift the standard of oral interviews undertaken by heritage professionals in New Zealand.

- Academics who teach these heritage students at New Zealand universities should also be encouraged to upskill to use oral interviews for built heritage research too or bring in experts to do so. They are well placed to encourage changes to how oral history is perceived in both academics' and practitioners' circles.

- Established heritage practitioners, including heritage consultants, conservation architects, researchers and other professionals working within heritage fields should be encouraged to broaden their research process to include oral history when appropriate. They should be challenged to rethink their processes and encouraged to consider the richness that oral history can bring to their work.

- Stakeholders like Heritage New Zealand, the Wellington City Council or the Ministry for Culture and Heritage should consider the additional benefit that oral history can 
bring to their projects and build time and funding for oral history into their contractual agreements when they employ researchers for built heritage projects.

These groups could all benefit from completing specialist training in oral history through attendance of courses like the one run by the National Library of New Zealand, or their skills could be honed by experimenting independently. This data can then flow through to better and more informed conservation plans, heritage inventory entries, histories, reports and other published and unpublished heritage documents.

This thesis argues that if we use oral history as a methodology in heritage studies we can engage with material that is impossible to glean from any other source to produce work that is enhanced by the richness of the data generated by this approach. Although this thesis acknowledges some limitations of this methodology, they are outweighed by the advantages. The most effective approach to oral history interviews is through identification of, and conversations around, numinous fabric. This enables us to engage with the stories that deepen our understanding of a building, which will in turn flow through to bolster the depth and quality of the material produced by heritage academics and heritage management practitioners. By doing this, we meet the challenge issued by Sørensen and Carman in their book Heritage Studies: Methods and Approaches, which challenges us to use oral history in a heritage context and inspired this thesis. 


\title{
Appendix 1 - Consent to Interview Form
}

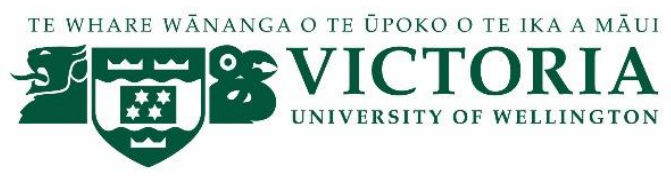

\section{Building Stories: Oral History and Built Heritage}

\author{
CONSENT TO INTERVIEW
}

This consent form will be held for 3 years.

Researcher: Miranda Williamson, School of Art History, Classics and Religious Studies, Victoria University of Wellington

- I have read the Information Sheet and the project has been explained to me. My questions have been answered to my satisfaction. I understand that I can ask further questions at any time.

- I agree to take part in an audio recorded interview.

I understand that:

- I may withdraw from this study at any point before 31 January 2018, without giving any reason, and any information that I have provided will be returned to me or destroyed.

- The information I have provided will be destroyed 3 years after the research is finished.

- $\quad$ Any information I provide will be kept confidential to the researcher and the supervisor. I understand that the results will be used for a Masters thesis and a summary of the results may be used in academic reports and/or presented at conferences.

- $\quad$ EITHER I consent to information or opinions which I have given being attributed to me in any reports on this research:

Yes

OR I would like a pseudonym rather than my real name:

Yes

- I would like an audio copy of my interview:

Yes

No 
- I would like a copy of my interview offered to the Alexander Turnbull Library:

Signature of participant:

Name of participant:

Date:

Contact details: 


\title{
Appendix 2 - NOHANZ Oral History Recording Agreement
}

\section{Oral History Recording Agreement}

\author{
Name of Project: \\ Full Name of Person Interviewed: \\ Date of Interview: \\ Commissioner: \\ Interviewer:
}

1. Placement: I, the person interviewed, agree that the recording of my interview and accompanying material, prepared for archival purposes, will be deposited in.

And copies may also be held by

Notes:

2. Access: I agree that the recording of my interview and accompanying material may be made freely available for research at the above location, or a location approved by the commissioner.

\section{YES $\square$ OR NO}

If NO: I require that there be NO access to the recording of my interview and accompanying material without my prior written permission until:

Release Date: OR Review Date: (select one only)

Notes:

3. Publication: I agree that the recording of my interview and accompanying material may be quoted or shown in full or in part; this includes broadcast, published work, use in public performances, and electronic publication on the internet.

YES $\square$ OR NO

If NO: I require there be NO publication of the recording of my interview and accompanying material without my prior written permission until:

Release Date:

OR Review Date: (select one only)

Notes:

Go to page 2 to complete form and sign at end 


\section{Copyright}

\section{Choose one:}

4a) Any copyright I own in the interview is retained by me, the interviewee

AND

(Complete if required) Any copyright owned by me at my death is assigned to [INSERT NAME]

OR

4b) Any copyright I own in the interview is assigned by me the interviewee to [INSERT NAME]

Notes:

5 Privacy Act: As interviewee I acknowledge that this agreement does not modify my rights and responsibilities under the Privacy Act 1993

\section{Additional Information:}

\section{Signatures:}

Person Interviewed Date:

Interviewer: Date:

For Commissioner: Date:

\section{Alternative contact (Optional):}

If I am incapable of exercising any of my rights under the Agreement please contact [INSERT NAME].

\section{Notes:}

1. All signatories to this Oral History Recording Agreement must comply with any restrictions on access/publication. This obligation applies to all copies of the recording and accompanying material, wherever they are held.

2. The terms agreed to in this Oral History Recording Agreement may be amended only with the authority of the person interviewed. Any change must be registered with all holders of the interview and accompanying material.

3. Commissioners, Interviewers and Repositories have responsibilities under the Privacy Act 1993.

4. The Interviewee should be credited as the speaker in any use of the recording.

Approved by the National Oral History Association of New Zealand

Te Kete Körero-a-Waha o Te Motu 


\section{Appendix 3 - Interview Questions}

What is your full name and when and where were you born?

Please tell me a little bit about yourself and your background.

What is your connection to the building Ngaroma?

Can you tell me about your first impressions of Ngaroma?

Can you describe the house and grounds to me?

Can you tell about daily life there?

Can you tell me about some of the personalities that you remember from Ngaroma?

Can you look at these original 1926 building plans and tell me what these rooms were used for when you were there?

Are there any stories you can tell me about Ngaroma and life there?

Do you remember your time at Ngaroma as a positive experience?

When and why did your connection with Ngaroma end? 


\section{Bibliography}

\section{Primary Sources}

\section{Wellington City Council Archives}

00009:437:9/283, Boarding House, Queens Drive, City Engineer's Files, 1949-1973.

00009:1684:45/62/66, Premises, 112 Queens Drive, City Engineer's File, 1890-2008.

00056:208:B18008, 112 Queens Drive, reinstatement of dwelling, Owner: Hope Gibbons. Builder: A H Collin, 1938.

00056:345:B26649, 112 Queens Drive, steel huts and alterations, Owner: T O'Shea and A Jackman, Builder: Lloyds McKenzie, 25 February 1948.

00056:369:B28357, 112 Queens Drive, convent, Owner: T O’Shea and AJ McRae. Builder: Lloyds McKenzie, 13 July 1949.

00056:384:B26808, 112 Queens Drive, hostel, Owner: T O’Shea and J McRae. Builder: Lloyds McKenzie, 26 April 1948.

00056:467:B35393, 112 Queens Drive, fowl-house, Owner: Ursuline Hostel. Builder: DP O’Neill, 13 November 1953.

00056:9:B887, 112 Queens Drive, dwelling, Owner: Hope B Gibbons. Builder: JM Dawson, 18 March 1926.

00058:789:C35485, 112 Queens Drive, dwelling additions - one bedroom, Legal description: Lots 32, 33, 65 and 9 DP 1889, Lot 65 DP 1889, Owner: Apostolic Church Delegation. Builder: J Ehrlich and Co. Application value: \$2400. Floor area: 135 square feet, 31 May 1972.

00138:0:8703, Group photograph outside the Adelaide Road tram barns on the occasion of the municipalisation of the tramways, 1900.

00138:0:11593, Elevated view of a wooden dwelling overlooking Lyall Bay [112 Queens Drive], c 1896. 
00432:431:36247, 112 Queens Drive, Private drainage connection application plans 18921992, Applicant: Archbishop O'Shea, 1940.

\section{Certificates of Title from Land Information New Zealand}

CT WN12D/819

CT WN19A/696

CT WN175/225

CT WN593/263

\section{Interviews}

Bisley, Jacqui, 16 August 2017, Lyall Bay, Wellington.

Campbell, Maria, 14 June 2017, Alicetown, Wellington.

Fahey, Carmel, 30 June 2017, Kilbirnie, Wellington.

Fejos, Steve, 27 June 2017, Northland, Wellington.

Gibbons, John, 6 June 2017, Wellington City.

Hampton, Chris, 27 April 2017, Miramar, Wellington.

Papp, Mary (née Takacs), 6 July 2017, Miramar, Wellington.

Sondej, Stefania (née Manterys), 26 July 2017, Korokoro, Wellington.

Zawada, Stefania (née Sondej) 11 May 2017, Alicetown, Wellington. 


\section{Secondary Sources}

\section{Newspapers and Magazines}

“Apostolic Delegation for New Zealand, South Pacific.” The Catholic Weekly, 26 December 1968.

Dasler, Yvonne. "The Hope Gibbons.” Wellington City Magazine, August 1985.

"Death of Prominent Personality in The Motor Industry." The Dominion, 10 December 1955.

“Early Days of City Recalled by Mr Hayward.” The Dominion, 27 October 1948.

“Golden Wedding.” Evening Post, 3 June 1936.

“Golden Wedding.” Hutt News, 10 June 1936.

“Lyall Bay Papal Retreat during Whirlwind Tour.” Western Suburbs News, 1 December 1986.

“Marriage.” New Zealand Times, 8 June 1886.

Pacific Pilgrimage: A Pictorial View of Pope John Paul II's Visit Nov. 22-24, 1986. New Zealand: Independent Newspapers, 1986.

"Papal Splendour.” Eastern Suburbs News, 24 April 1990.

"Refugees from Hungary.” Labour and Employment Gazette VII, no. 2 (May 1957): 14-18. 
Ross, Annabell. “Unwanted.” New Zealand Freelance, 29 April 1959.

“Saturday's Bride, Miss Paddy Hope Gibbons, Elder Daughter of Mr and Mrs Hope B. Gibbons, "Ngaroma,...[Truncated]." Evening Post, 10 September 1945.

“The Nunciature Closes.” St Patricks Church News \& Views, April 2015.

“The Social Sphere.” The New Zealand Observer, 23 July 1931.

"The Ursuline Sisters Come to Kilbirnie." The Record: The Monthly Journal of St Patrick's Parish, Kilbirnie, February 1948.

“Too Few Girls—Lyall Bay Hostel Closing Down.” Evening Post, 11 August 1969.

\section{Books}

Abrams, Lynn. Oral History Theory. London and New York: Routledge, second edition, 2016.

Benton, Tim. Understanding Heritage and Memory. Manchester and New York: Manchester University Press, 2010.

Cauvin, Thomas. Public History: A Textbook of Practice. New York and Oxon: Routledge, 2016.

Classen, Constance. Worlds of Sense: Exploring the Senses in History and Across Cultures. London and New York: Routledge, 1993. 
The Cyclopedia of New Zealand: Industrial, Descriptive, Historical, Biographical Facts, Figures, Illustrations. Wellington: The Cyclopedia Company, 1897.

Dalley, Bronwyn, and Jock Phillips, eds. Going Public: The Changing Face of New Zealand History. Auckland: Auckland University Press, 2001.

Damousi, Joy, and Paula Hamilton, eds. A Cultural History of Sound, Memory and the Senses. New York and Oxon: Routledge, 2017.

Denscombe, Martyn. The Good Research Guide: For Small-Scale Social Research Projects. Maidenhead: McGraw-Hill/Open University Press, fourth edition, 2010.

Evans, George Ewart. Ask the Fellows Who Cut the Hay. London: Faber, second edition, 1962.

Fairclough, Graham, Rodney Harrison, John H. Jameson Jnr., and John Schofield, eds. The Heritage Reader. London and New York: Routledge, 2008.

Frisch, Michael. A Shared Authority: Essays on the Craft and Meaning of Oral and Public History. Albany: State University of New York Press, 1990.

Gray, David E. Doing Research in the Real World. Los Angeles: SAGE, second edition, 2009.

Green, Anna, and Megan Hutching, eds. Remembering: Writing Oral History. Auckland: Auckland University Press, 2004.

Green, Anna, and Kathleen Troup. The Houses of History: A Critical Reader in Twentieth-Century History and Theory. Manchester: Manchester University Press, 1999. 
Hamilton, Paula, and Linda Shopes. Oral History and Public Memories. Philadelphia: Temple University Press, 2008.

High, Steven C. Oral History at the Crossroads: Sharing Life Stories of Survival and Displacement. Vancouver: UBC Press, 2014.

Hodgson, Terence E. R. The Big House: Grand \& Opulent Houses in Colonial New Zealand. Auckland: Random Century, 1991.

Humphris, Adrian, and Geoff Mew. Ring around the City: Wellington's New Suburbs, 1900-1930. Wellington: Steele Roberts, 2009.

Irvine-Smith, F. L. The Streets of My City; Wellington, New Zealand. Wellington and Auckland: Reed, second edition, 1967.

Kean, Hilda, and Paul Martin, eds. The Public History Reader. Oxford and New York: Routledge, 2013.

Kovesi, Catherine. Pitch Your Tents on Distant Shores: A History of the Sisters of the Good Shepherd in Australia, Aotearoa/New Zealand and Tahiti. Caringbah: Playright Publishing, 2006.

Lawlor, Pat. Old Wellington Days. Wellington: Whitcombe \& Tombs Limited, 1959.

Manterys, Adam, Stanislaw Manterys, Józef Zawada, Stefania Zawada, and Polish Children's Reunion Committee. New Zealand's First Refugees: Pahiatua's Polish Children. Wellington: Polish Children's Reunion Committee, fourth edition, 2016.

Mew, Geoff, and Adrian Humphris. Raupo to Deco: Wellington Styles and Architects, 1840-1940. Wellington: Steele Roberts Aotearoa, 2014. 
Moriarty, Julia Mary. Jubilee 1919-1969. Issued by the Parish Council, St Patricks Parish, Kilbirnie, New Zealand, in Commemoration of the 50th Anniversary, September 14-21,1969. Wellington: Futuna Press, 1969.

Munro, Jessie. The Story of Suzanne Aubert. Auckland: Auckland University Press and Bridget Williams Books, 1996.

O'Meeghan, Michael. Steadfast in Hope: The Story of the Catholic Archdiocese of Wellington 1850 2000. Palmerston North: Dunmore Press, 2003.

Portelli, Alessandro. The Death of Luigi Trastulli, and Other Stories: Form and Meaning in Oral History. Albany, N.Y.: State University of New York Press, 1991.

Rosen, Alan. The Wonder of Their Voices: The 1946 Holocaust Interviews of David Boder. Oxford; New York: Oxford University Press, 2010.

Schrader, Ben. The Big Smoke: New Zealand Cities, 1840-1920. Wellington: Bridget Williams Books, 2016.

We Call It Home: A History of State Housing in New Zealand. Auckland: Reed, 2005.

Smith, Mark M. Sensing the Past: Seeing, Hearing, Smelling, Tasting, and Touching in History. California: University of California Press, 2007.

Sørensen, Marie Louise Stig, and John Carman, eds. Heritage Studies: Methods and Approaches. London and New York: Routledge, 2009. 
Thompson, Paul. The Voice of the Past: Oral History. New York: Oxford University Press, third edition, 2000.

Wises New Zealand Post Office Directory. New Zealand: H Wise \& Co Ltd, 1918.

Yow, Valerie Raleigh. Recording Oral History: A Guide for the Humanities and Social Sciences. Third edition. Lanham: Rowman \& Littlefield, 2015.

\section{Chapters in Edited Collections}

Benton, Tim, and Clementine Cecil. "Heritage and Public Memory." In Understanding Heritage and Memory, edited by Tim Benton, 7-43. Manchester and New York, 2010.

Butler, Toby. “"Memoryscape': Integrating Oral History, Memory and Landscape on the River Thames." In Public History and Heritage Today: People and Their Pasts, edited by Paul Ashton and Hilda Kean, 223-239. Basingstoke and New York: Palgrave Macmillan, 2008.

— . "The Historical Hearing Aid: Located Oral History from the Listener's Perspective.” In Place, Writing, and Voice in Oral History, edited by Shelley Trower, 193-215. New York: Palgrave Macmillan, 2011.

Carman, John, and Marie Louise Stig Sørensen. "Heritage Studies: An Outline.” In Heritage Studies: Methods and Approaches, edited by Marie Louise Stig Sørensen and John Carman, 11-28. London and New York: Routledge, 2009.

Cenker, Iş1 Cerem and Lucienne Thys-Şenocak. "Moving Beyond the Walls: The Oral History of the Ottoman Fortress Villages of Seddulbahir and Kumkale." In Oral History and Public Memories, edited by Paula Hamilton and Linda Shopes, 65-86. Philadelphia: Temple University Press, 2008. 
Davison, Graeme. "Heritage: From Patrimony to Pastiche.” In The Heritage Reader, edited by Graham Fairclough, Rodney Harrison, John H. Jameson Jnr, and John Schofield, 31-41. London and New York: Routledge, 2008.

Freund, Alexander, and Alistair Thomson. "Introduction: Oral History and Photography." In Oral History and Photography, edited by Alexander Freund and Alistair Thomson, 1-23. New York: Palgrave Macmillan, 2012.

Green, Anna. "Oral History and History." In Remembering: Writing Oral History, edited by Anna Green and Megan Hutching, 1-8. Auckland: Auckland University Press, 2004.

_ . “Unpacking' the Stories." In Remembering: Writing Oral History, edited by Anna Green and Megan Hutching, 9-24. Auckland: Auckland University Press, 2004.

Haley, Alex. "Black History, Oral History and Genealogy." In The Oral History Reader, edited by Robert Perks and Alistair Thomson, 22-32. London and New York: Routledge/Taylor \& Francis Group, 2016.

Hamilton, Paula. "Oral History and the Senses." In The Oral History Reader, edited by Robert Perks and Alistair Thomson, 104-116. London and New York: Routledge/Taylor \& Francis Group, 2016.

Hamilton, Paula and Linda Shopes. "Introduction: Building Partnerships Between Oral History and Memory Studies", In Oral History and Public Memories, edited by Paula Hamilton and Linda Shopes, vii-xvii. Philadelphia: Temple University Press, third edition, 2008.

Harrison, Rodney, Graham Fairclough, John H. Jameson, and John Schofield. "Introduction: Heritage, Memory and Modernity.” In The Heritage Reader, edited by Graham Fairclough, Rodney Harrison, John H. Jameson Jnr, and John Schofield, 1-12. London; New York: Routledge, 2008. 
Keenan, Danny. "The Past from the Paepae: Uses of the Past in Maori Oral History", In Remembering: Writing Oral History, edited by Anna Green and Megan Hutching, 145-151. Auckland: Auckland University Press, 2004.

Kerr, James Semple. “The Conservation Plan.” In The Heritage Reader, edited by Graham Fairclough, Rodney Harrison, John H. Jameson Jnr, and John Schofield, 322-330. London and New York: Routledge, 2008.

McLean, Gavin. "Where Sheep May Not Safely Graze: A Brief History of New Zealand's Heritage Movement 1890-2000." In Common Ground?: Heritage and Public Places in New Zealand, edited by Alexander Trapeznik, 25-44. Dunedin: University of Otago Press, 2000.

O'Shea-Miles, Cathy. “The Women of Irishtown”, In Remembering: Writing Oral History, edited by Anna Green and Megan Hutching, 77-89. Auckland: Auckland University Press, 2004.

Perks, Robert, and Alistair Thomson. "Critical Developments: Introduction.” In The Oral History Reader, edited by Robert Perks and Alistair Thomson, 1-21. London and New York: Routledge/Taylor \& Francis Group, third edition, 2016.

Phillips, Jock, and Bronwyn Dalley. "Introduction.” In Going Public: The Changing Face of New Zealand History, edited by Bronwyn Dalley and Jock Phillips, 7-13. Auckland: Auckland University Press, 2001.

Schofield, John. "Heritage Management, Theory and Practice." In The Heritage Reader, edited by G. J. Fairclough, Rodney Harrison, John H. Jameson Jnr, and John Schofield, 15-30. London and New York: Routledge, 2008.

Sørensen, Marie Louise Stig. "Between the Lines and in the Margins: Interviewing People About Attitudes to Heritage and Identity." In Heritage Studies: Methods and Approaches, edited by Marie Louise Stig Sørensen and John Carman, 164-177. London and New York: Routledge, 2009. 
_ . "Introduction: Making the Means Transparent: Reasons and Reflections." In Heritage

Studies: Methods and Approaches, edited by Marie Louise Stig Sørensen and John Carman, 3-10. London and New York: Routledge, 2009.

Trapeznik, Alexander. "Introduction.” In Common Ground?: Heritage and Public Places in New Zealand, edited by Alexander Trapeznik, 9-23. Dunedin: University of Otago Press, 2000.

Trower, Shelley. “Introduction.” In Place, Writing, and Voice in Oral History, edited by Shelley Trower, 1-19. New York: Palgrave Macmillan, 2011.

\section{Journal Articles}

Ashton, Paul. "Introduction: Going Public.” Public History Review 17 (1 December 2010): 1-15.

Cameron, Catherine M., and John B. Gatewood. "Excursions into the Un-Remembered Past: What People Want from Visits to Historical Sites.” The Public Historian 22, no. 3 (2000): 107-27.

Freeman, Lindsey A., Benjamin Nienass, and Rachel Daniell. "Memory | Materiality | Sensuality." Memory Studies 9, no. 1 (2016): 3-12.

Gardner, James B. “Contested Terrain: History, Museums, and the Public.” The Public Historian 26, no. 4 (2004): 11-21.

Gatley, Julia. "Life at the Rotherham House in the 1950s and 1960s." Fabrications: The Journal of the Society of Architectural Historians, Australia and New Zealand 24, no. 2 (3 July 2014): 244-267. 
Gentry, Kynan. “"The Pathos of Conservation': Raphael Samuel and the Politics of Heritage.” International Journal of Heritage Studies 21, no. 6 (2 September 2014): 1-16.

Kean, Hilda. "Public History and Raphael Samuel: A Forgotten Radical Pedagogy?" Public History Review 11 (2004): 51-62.

Latham, Kiersten F. "Numinous Experiences With Museum Objects.” Visitor Studies 16, no. 1 (1 January 2013): 3-20.

Lusaka, Mwayi. "Memory, Oral History and Conservation at Robben Island's Bluestone Quarry." South African Historical Journal 69, no. 4 (2 October 2017): 583-597.

Maines, Rachel P., and James J. Glynn. "Numinous Objects.” The Public Historian 15, no. 1 (1 January 1993): 9-25.

Norrick, Ned R. "Humour in Oral History Interviews." Oral History: The Journal of the Oral History Society 34, no. 2 (2006): 85-94.

Passerini, Luisa. "Work Ideology and Consensus under Italian Fascism.” History Workshop 0, no. 8 (1 October 1979): 82.

Riley, Mark, and David Harvey. "Landscape Archaeology, Heritage and the Community in Devon: An Oral History Approach.” International Journal of Heritage Studies 11, no. 4 (2005): 269-288.

Samuel, Raphael. "Local History and Oral History.” History Workshop, no. 1 (1 April 1976): 191208.

Shopes, Linda. "Oral History and the Study of Communities: Problems, Paradoxes, and Possibilities." Journal of American History 89, no. 2 (2002): 588-598. 
Skillen, Fiona, and Carol Osborne. "It's Good to Talk: Oral History, Sports History and Heritage." The International Journal of the History of Sport 32, no. 15 (4 February 2016): 1-16.

Stein, Jesse Adams. "The Co-Construction of Spatial Memory: Enriching Architectural Histories of 'Ordinary' Buildings." Fabrications: The Journal of the Society of Architectural Historians, Australia and New Zealand 24, no. 2 (3 July 2014): 178-197.

Thomson, Alistair. "Four Paradigm Transformations in Oral History." Oral History Review 34, no. 1 (2007): 49-70.

\section{Reports and Conservation Plans}

Cochran, Chris. "St Joseph’s Church \& Convent Conservation Plan,” 2004.

“NZ Historic Places Trust Inventory,” n.d.

Warren-Findley, Janelle. "Human Heritage Management in New Zealand in the Year 2000 and Beyond," 2001.

\section{Theses}

Kemp, Neil. “King \& Dawson: An Historical Study, 1906-1981.” Victoria University of Wellington, 1982.

Marcus, Benjamin. "Last One In: Community, Conflict and the Preservation of McCarren Park Pool." Colombia University, 2006. 


\section{Websites and DVDs}

Auckland War Memorial Museum. "Hopeful Hope Gibbons.” Auckland War Memorial Museum. Accessed 3 August 2017. http://www.aucklandmuseum.com/war-memorial/onlinecenotaph/record/C24295.

Beaglehole, Ann. "2. - Hungarians." Te Ara The Encyclopedia of New Zealand. Accessed 3 August 2017. /en/hungarians/page-2.

Beaglehole, Diana. “Gibbons, Hopeful.” Te Ara: The Encyclopedia of New Zealand. Accessed 3 August 2017. /en/biographies/3g5/gibbons-hopeful.

"Borough Of Melrose | NZETC." Accessed 2 August 2017. http://nzetc.victoria.ac.nz/tm/scholarly/tei-Cyc01Cycl-t1-body-d4-d64-d3.html\#name-414593mention.

Brew, Robin, Shane Loader, Eva Radich, Marie Russell, Community Media Trust, and Screen Innovation Production Fund. A Place to Stay a Film about Salisbury Garden Court. Wellington, N.Z.: Community Media Trust, 2009.

Conservation (DOC), New Zealand Department of. "Department of Conservation." Accessed 12 August 2018. https://www.doc.govt.nz/.

“Good Shepherd New Zealand.” Accessed 3 August 2017. http://www.goodshepherd.org.nz/aboutus/our-history-in-new-zealand/.

“Heritage New Zealand.” Accessed 12 August 2018. http://www.heritage.org.nz/.

"Homepage | Ministry for Culture and Heritage.” Accessed 12 August 2018. https://mch.govt.nz/.

Kerr, James Semple. “The Conservation Plan | Australia ICOMOS.” Accessed 3 August 2018. https://australia.icomos.org/publications/the-conservation-plan/.

"Mt Victoria Historical Society George Winder." Accessed 2 August 2017. http://mtvictoria.history.org.nz/george-winder/. 
“Old St Paul's Wellington New Zealand.” Old St Paul's Wellington New Zealand. Accessed 30 July 2018. https://osphistory.org/.

“PHANZA - Professional Historians' Association of NZ." Accessed 2 August 2018. http://phanza.org.nz/.

“Wellington City Council.” Accessed 12 August 2018. https://wellington.govt.nz/. 